\title{
Sorghum Genetic Resources, Cytogenetics, and Improvement
}

\author{
Belum V.S. Reddy, S. Ramesh, and P. Sanjana Reddy
}

\section{CONTENTS}

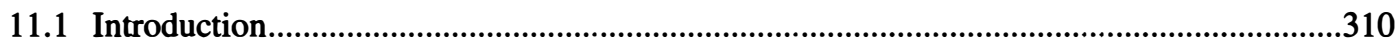

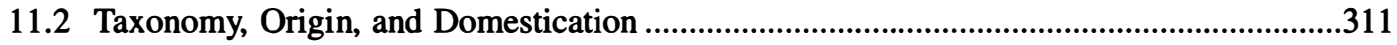

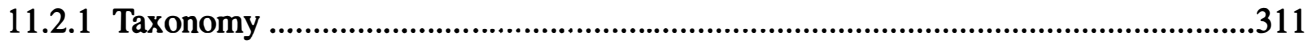

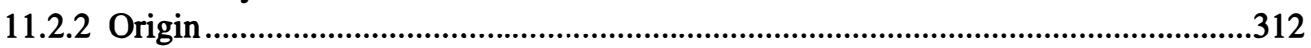

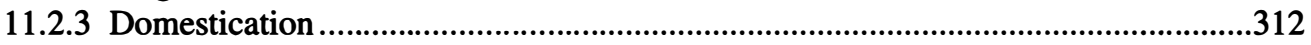

11.3 Breeding Behavior and Pollination Control..............................................................313

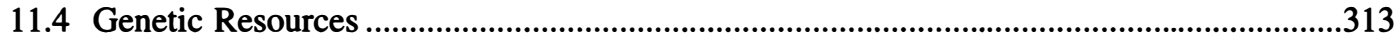

11.4.1 Importance and Need for Conservation .........................................................313

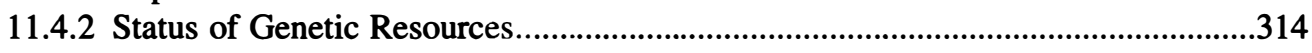

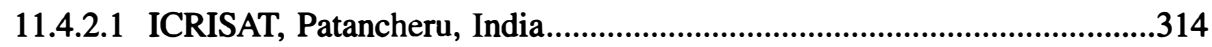

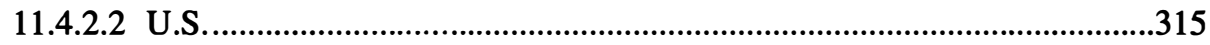

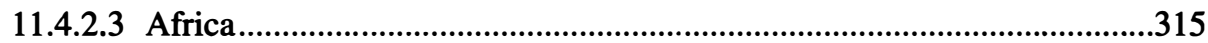

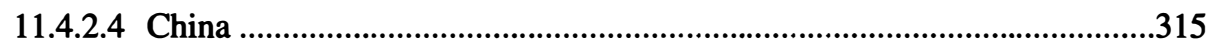

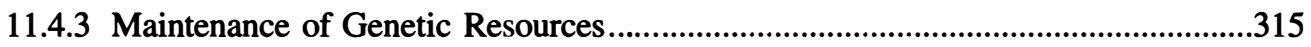

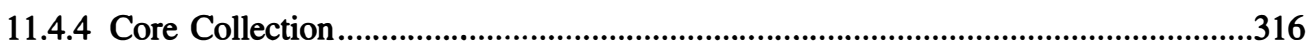

11.4.5 Evaluation, Characterization, and Documentation of Genetic Resources................316

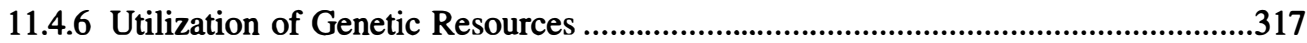

11.5 Genetic Variability for Qualitative and Quantitative Traits .............................................318

11.5.1 Morphological/Phenotypic Level .....................................................................318

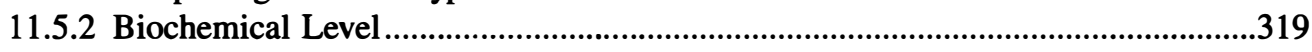

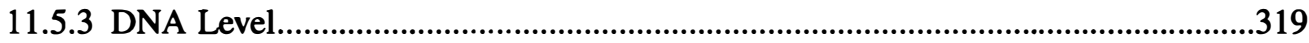

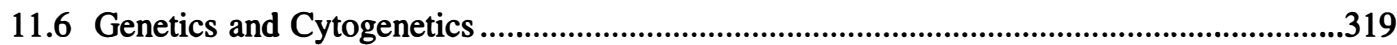

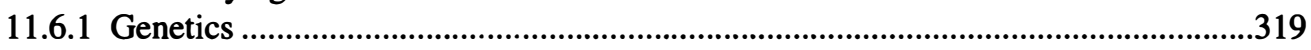

11.6.1.1 Genetics of Morphological and Resistant Traits ...................................319

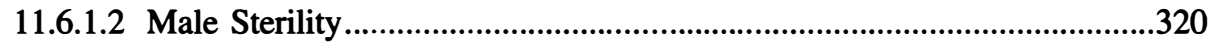

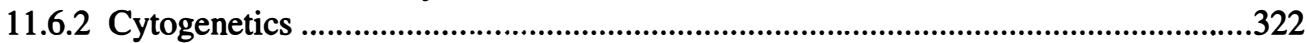

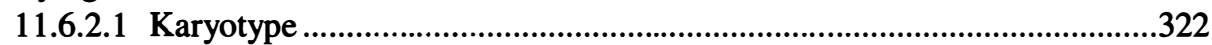

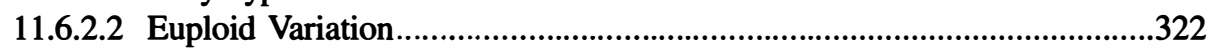

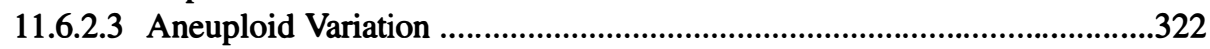




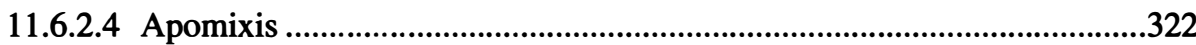

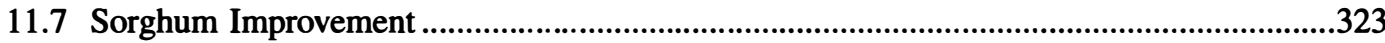

11.7.1 Environmental Response Characteristics ..........................................................323

11.7.2 Conversion Programs..................................................................................................323

11.7.3 Breeding Concepts and Breeding Material..............................................................324

11.7.3.1 Breeding Concepts ...................................................................................324

11.7.3.2 Breeding Materials...................................................................................325

11.7.4 Adaptation and Productivity Enhancement...........................................................325

11.7.5 Trait-Based Breeding.................................................................................................326

11.7.5.1 Grain Yield and Adaptation .......................................................................326

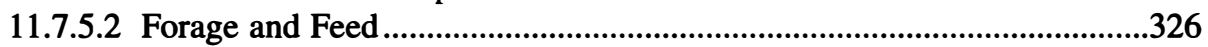

11.7.5.3 Resistance to Foliar, Stem, and Head Feeding Insects .............................328

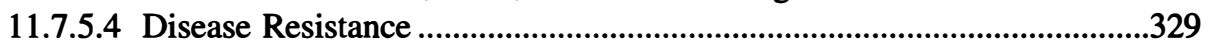

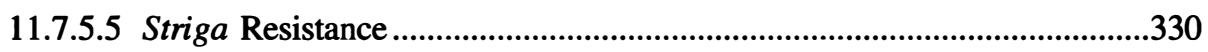

11.7.5.6 Drought Tolerance...........................................................................332

11.7.5.7 Soil Chemical Toxicity Tolerance................................................................334

11.7.5.8 Increased Nutritional Quality....................................................................336

11.7.5.9 Increased Micronurient Density ……………….......................................338

11.8 New Tools for Sorghum Improvement ...............................................................................339

11.8.1 Farmers' Participatory Approach...............................................................................339

11.8.2 Biotechnology ......................................................................................................340

11.8.2.1 DNA Marker Technology .......................................................................340

11.8.2.2 Genetic Transformation Technology .............................................................344

11.8.2.3 Transgenics and Conventional Breeding Integrated Technology ...............344

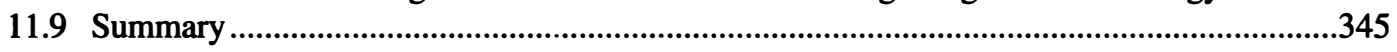

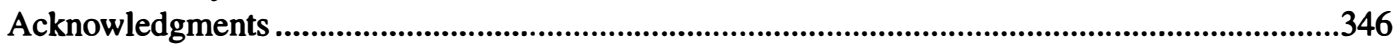

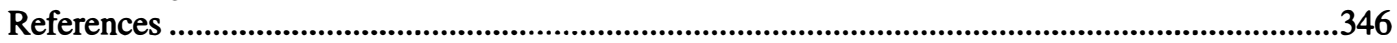

\subsection{INTRODUCTION}

Sorghum (Sorghum bicolor (L.) Moench) is the world's fourth major cereal crop in terms of production, and fifth in acreage following wheat, rice, maize, and barley. Sorghum is mostly grown in the semiarid tropics (SAT) of the world as a subsistence dry-land crop by resource-limited farmers under traditional management conditions, thereby recording low productivity compared to the U.S. and Mexico. India grows the largest acreage of sorghum in the world, followed by Nigeria and Sudan, and produces the second largest tonnage after the U.S., with Nigeria being the third largest producer. In most of the regions of India, it is cultivated both as a rainy- and postrainy-season crop.

The yield and quality of sorghum produced worldwide is influenced by a wide array of biotic and abiotic constraints. Table 11.1 outlines the major biotic factors affecting sorghum production. The parasitic weed Striga ( $S$. asiatica, S. densiflora, S. hermonthica) is prevalent in many regions of Africa and India and significantly impacts sorghum production. Abiotic constraints to sorghum production include soil properties (acidity and associated $\mathrm{Al}^{3+}$ toxicity, salinity), extremes in temperature, and drought.

Grain sorghum quality is determined by several factors, such as visual quality, nutritional quality (including whole grain, protein, and starch digestibility; nutrient bioavailability), antinutritional factors such as tannins, processing characteristics, cooking quality, and consumer acceptability. Hulse et al. (1980) published an exhaustive review of chemical composition and nutritive value of sorghum grain. In India, grain produced in the postrainy season is highly valued for human food, while the grain produced in the rainy season has poor quality due to grain mold incidence. 
Table 11.1 Major Biotic Factors Affecting Global Sorghum Production

\begin{tabular}{ll}
\hline \multicolumn{1}{c}{ Insects } & \multicolumn{1}{c}{ Diseases } \\
\hline Shoot fly (Atherigona soccata Rondani) & Grain mold (several genera) \\
Stem borer (Chilo partellus) & Charcoal rot (Macrophomina phaseolina) (Tassi) Goidanich \\
Midge (Contarinia sorghicola Coq.) & Downy mildew (Peronosclerospora sorghi) \\
Head bug (Eurystylus oldi Poppius) & Anthracnose (Colletotrichum graminicola) G.W. Wils. \\
Greenbug (Schizaphis graminum) (Rondani) & Rust (Puccinia purpurea) \\
Armyworms (Spodoptera exempta) & Leaf blight (several genera) \\
Locusts (several genera) & Several viral diseases \\
\hline
\end{tabular}

Traditional foods made from sorghum include unfermented and fermented breads, porridges, couscous, boiled rice-resembling foods, and snacks, as well as alcoholic beverages. Sorghum blended with wheat flour is used to produce baked products, including yeast-leavened pan, hearth and flat breads, cakes, muffins, cookies, biscuits, and flour tortillas (Badi et al. 1990). Hard endosperm sorghum is used extensively in Southeast Asia for noodles and related products (Murty and Kumar 1995).

Grain sorghum is used to make products such as potable alcohol, malt, beer, liquids, gruels, starch, adhesives, core binders for metal casting, ore refining, and grits as packaging material. Grains are a rich and cheap source of starch and have applications in the food, pharmaceutical, textile, and paper industries. Malt drinks and malt cocoa-based weaning food and baby food industries are popular in Nigeria.

Sorghum grain is used for animal feed in the U.S., China, and South America, while in Africa and Asia the grain is used as human food (either directly or after brewing), with the dried stalks used for fodder, building materials, and fuel (Chandel and Paroda 2000). Sorghum is also grown for forage and is commonly grown in northern India and western Africa and fed to animals as a green chop, silage, or hay. Sweet sorghum is used to a limited extent in producing sorghum syrup and jaggery in India, and as a source of biofuel-alcohol in Brazil. Sweet sorghum stems are sold for chewing in many places of Africa and India.

Sorghum grain is one of the major ingredients in swine, poultry, and cattle feed in the western hemisphere (Bramel-Cox et al. 1995); however, demand for grain sorghum in poultry feed depends largely on the price of maize. More research is needed for its inclusion in poultry and dairy feed rations (Kleih et al. 2000).

Sorghum therefore assumes greater importance in the economics of several countries in Africa and Asia, largely inhabited by resource-limited farmers. Although wide ranges of traditional, novel, and industrially important products are produced from sorghum, the quality of products, such as ethanol, extrusion breakfast foods, etc., needs to be improved by utilizing the variability present in the crop.

\subsection{TAXONOMY, ORIGIN, AND DOMESTICATION}

\subsubsection{Taxonomy}

Linnaeus first described sorghum in 1753 under the genus Holcus. In 1794, Moench defined the genus Sorghum (from Holcus) to contain two species (Celarier 1959; Clayton 1961). Since then, Sorghum has undergone many taxonomic treatments to become the genus recognized today. Many authors have discussed the systematics, origin, and evolution of sorghum since Linnaeus (de Wet and Huckabay 1967; de Wet and Harlan 1971; Doggett 1988; Dahlberg 2000). Although sorghum is a diploid (or diploidized) cereal, it seems to have resulted from an ancestral round of polyploidy (see Chapter 1 by Jauhar in this volume). 
Table 11.2 The 15 Races of Cultivated Sorghum bicolor subsp. bicolor

\begin{tabular}{ll}
\hline \multicolumn{1}{c}{ Basic Races } & \multicolumn{1}{c}{ Intermediate/Hybrid Races } \\
\hline 1. Race bicolor (B) & 6. Race guinea-bicolor (GB) \\
2. Race guinea (G) & 7. Race caudatum-bicolor (CB) \\
3. Race caudatum (C) & 8. Race kafir-bicolor (KB) \\
4. Race kafir (K) & 9. Race durra-bicolor (DB) \\
5. Race durra (D) & 10. Race guinea-caudatum (GC) \\
& 11. Race guinea-kafir (GK) \\
& 12. Race guinea-durra (GD) \\
& 13. Race kafir-caudatum (KC) \\
& 14. Race durra-caudatum (DC) \\
& 15. Race kafir-durra (KD)
\end{tabular}

Sorghum is classified under the family Poaceae, tribe Andropogoneae, subtribe Sorghinae, and genus Sorghum Moench (Clayton and Renvoize 1986). Garber (1950) and Celarier (1959) divided the genera into five subgenera: Eu-sorghum, Chaetosorghum, Heterosorghum, Para-sorghum, and Stiposorghum. Chaetosorghum and Heterosorghum are found in single species primarily in Australia and the South Pacific. Para-sorghum includes seven species found in the eastern hemisphere and Central America, while Stiposorghum contains 10 species endemic to Australia (Dahlberg 2000). Lazarides et al. (1991) present an excellent overview of the species in each of these four subgenera.

The basic chromosome number of sorghum is five, although striking differences in chromosome number, modes of origin, chromosome size, and geographic distribution of species are observed. Celarier (1959) hypothesized five as the lowest chromosome number in the Para-sorghum and Stiposorghum species, with polyploid proposed as autopolyploidy building by units of 10 (i.e., $2 \mathrm{n}$ $=10,20$, and 30).

S. bicolor spp. bicolor contains all the cultivated sorghums and are described as annual, with stout culms up to $5 \mathrm{~m}$ tall, often branched, and frequently tillering (Doggett 1988). Harlan and de Wet (1972) developed a simplified classification of cultivated sorghum into 5 basic and 10 hybrid races (Table 11.2) that proved to be of real practical utility for sorghum researchers. The 15 races of cultivated sorghum are identified by mature spikelets alone, although head type is sometimes helpful (Figure 11.1). The classification is based on five fundamental spikelet types - race bicolor, guinea, caudatum, kafir, and durra - and is detailed in Harlan and de Wet (1972).

The International Plant Genetic Resources Institute (IPGRI) Advisory Committee on Sorghum and Millets germplasm has accepted and recommended this classification to be used in describing sorghum germplasm (IBPGR/ICRISAT 1980).

\subsubsection{Origin}

The origin and early domestication of sorghum is hypothesized to have taken place around 5000 to 8000 years ago in northeastem Africa or at the Egyptian-Sudanese border (Mann et al. 1983; Wendorf et al. 1992). There is no argument against the African origin of sorghum, with the largest diversity of cultivated and wild sorghum also found there (de Wet 1977; Doggett 1988; Kimber 2000). The secondary center of origin of sorghum is the Indian subcontinent, with evidence for early cereal cultivation discovered at an archaeological site in western parts of Rojdi (Saurashtra) dating back to about 4500 before 1950 A.D. (Vavilov 1992; Damania 2002).

\subsubsection{Domestication}

Sorghum, a grass of the steppes and savannas of Africa, was probably domesticated in the northeast quadrant of Africa, an area that extends from the Ethiopia-Sudan border westward to Chad (Doggett 1970; de Wet et al. 1976). From there, it spread to India, China, the Middle East, and Europe soon after its domestication (Doggett 1965). The great diversity of $S$. bicolor has been 
created through disruptive selection (i.e., selection for extreme types) and by isolation and recombination in the extremely varied habitats of northeast Africa and the movement of people carrying the species throughout the continent (Doggett 1988). It has been diversified into a food source, sugar source, and construction material. Harvesting of entire panicles of sorghum by people altered the selection process (Kimber 2000). The basic morphological difference between a domesticated and a wild sorghum is the presence or absence of an abscission zone at the rachis, panicle, or spikelet nodes (Harlan et al. 1973). The process of domestication involved a change in several characteristics of the plant. A tough primary axis (rachis) and persistence of sessile spikelet were introduced early in the process. It is likely that the transformation of a loose and open inflorescence into a compact type involved several changes: (1) an increase in the number of branches per node, (2) an increase in the number of branches per primary inflorescence branch, and (3) a decrease in the internode length on the rachis. An increase in seed size was also probably a product of domestication, the seed becoming large enough to protrude from the glume (House 1985).

\subsection{BREEDING BEHAVIOR AND POLLINATION CONTROL}

Genetic variability is a prerequisite for any plant breeding program, with selfing and crossing the essential tools to direct and control this genetic variation. The knowledge of breeding behavior is therefore essential to decide the method used to breed cultivars, including pure lines, populations, and hybrids (House 1985).

Sorghum is primarily a self-pollinated crop; however, outcrossing does occur. In varieties with compact or semicompact panicles, selfing can be up to 90 to $95 \%$, with 5 to $10 \%$ outcrossing (occurring more frequently at the tips of the panicles) (Doggett 1988). Varieties with loose or open panicles have higher rates of outcrossing: 30 to $60 \%$ (House 1985). In nature, the rate of outcrossing is affected by the wind as stigmas are most receptive during the first 3 to 5 days after their emergence, but can remain receptive up to a week or more after anthesis, depending upon temperature and humidity (Doggett 1988).

Hybridization, or crossing, of sorghum on a field scale is made feasible through genetic, cytoplasmic, and cytoplasmic-genetic male sterility systems (Stephens 1937; Ayyangar and Ponnaiya 1939; Stephens and Holland 1954). Limited scale crossing can be carried out through (1) emasculation with hot water and plastic bag technique or (2) hand emasculation and pollination techniques. Emasculation using hot water and plastic bags is cumbersome and requires a lot of preparation. It is safer to use hand emasculation, which can easily be done by unskilled staff with some training (House 1985).

\subsection{GENETIC RESOURCES}

\subsubsection{Importance and Need for Conservation}

Plant genetic resources are defined as the "genetic material of plants that is of value as a resource for the present and future generations of people" (IPGRI 1993). The importance of genetic resources was recognized at the intergovernmental platform under the umbrella of Food and Agricultural Organization (FAO) of the United Nations as the "common heritage of mankind," which should be made available without restriction (FAO 1983). Genetic resources have evolved as a product of domestication, intensification, diversification, and improvement through conscious and unconscious selection by countless generations of farmers. These landraces and improved cultivars provide the basic and strategic raw material for crop improvement the world over for present and future generations (Rai 2002). 


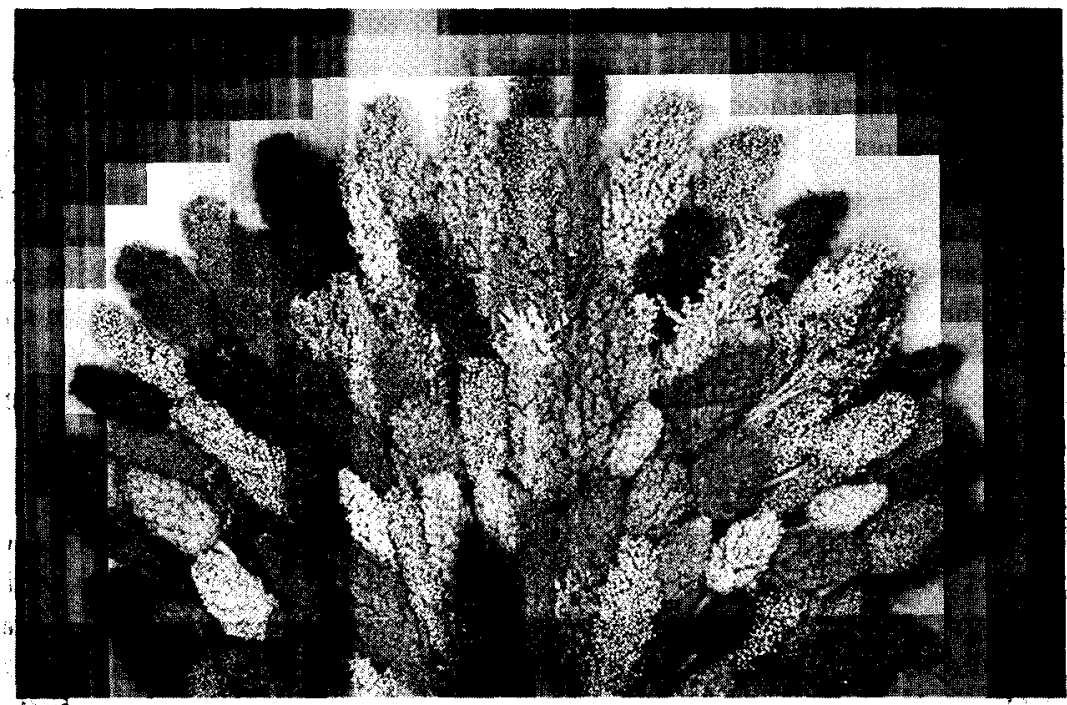

Sorghum genetic resources

Figure 11.1 (See color insert following page 114.) Genetic variability in sorghum is shown by a wide range of panicle colors.

Sorghum has an immense range of genetic resources (Figure 11.1), with much of the genetic variability available in the African regions where domestication first occurred, and in the Asian regions of early introduction. In Africa, the genetic variability occurs as cultivated species, wild crop progenitors, and wild species (de Wet and Harlan 1971; Gebrekidan 1982). Landraces and wild relatives of cultivated sorghum from the centers of diversity have been rich sources of resistance to new pathogens, insect pests, and other stresses, such as high temperature and drought, as well as sources of traits to improve food and fodder quality, animal feed, and industrial products. However, this natural genetic diversity is by the adoption of improved varieties. To prevent the extinction of landraces and wild relatives of cultivated sorghum, the collection and conservation of sorghum germplasm was accelerated about four decades ago. Since then, germplasm collection and conservation have become integral components of several crop improvement programs at both national and international levels (Rosenow and Dalhberg 2000).

\subsubsection{Status of Genetic Resources}

At the global level, sorghum germplasm collections consist of approximately 168,500 accessions; the largest collection ( $21 \%$ of global total) is held at the International Crops Research Institute for the Semi-Arid Tropics (ICRISAT), Patancheru, India. The total accessions consist of 18\% landraces/old cultivars, $21 \%$ advanced cultivars/breeding lines, $60 \%$ mixed categories of unknown material, while very few are wild relatives (Chandel and Paroda 2000). In this section, we will discuss the status of germplasm maintained at the ICRISAT, Patancheru, India, and at the National Plant Germplasm System (NPGS) in the U.S., as well as Africa and China, as these countries have large crop improvement programs (Rosenow and Dalhberg 2000).

\subsubsection{ICRISAT, Patancheru, India}

The Rockefeller Foundation in the Indian Agricultural Research Program initiated a sorghum collection in 1960 (Murty et al. 1967; House 1985). A total of 16,138 accessions was assembled from different countries, and international sorghum (IS) numbers were assigned to them. In 1976, ICRISAT added its sorghum germplasm to the world collection in accordance with the recommen- 
dations made by the Advisory Committee on Sorghum and Millet Germplasm sponsored by the International Board for Plant Genetic Resources (now the International Plant Genetic Resources Institute (IPGRI)) (IBPGR 1976; Prasada Rao et al. 1989).

At present, ICRISAT maintains 36,774 accessions from 90 countries, representing about $80 \%$ of the variability present in the crop (Eberhart et al. 1997). Most of the collections originated from developing countries in the semiarid tropics, with about $60 \%$ originating from India, Ethiopia, Sudan, Cameroon, Swaziland, and Yemen, the largest collection being from India. Landraces contribute $84 \%$ of the total collection compared with wild species, which contribute only $1 \%$. The germplasm maintained at ICRISAT are classified into five races - bicolor, guinea, caudatum, kafir, and durra - and their derivatives, predominantly represented by the three basic races: durra $(21.8 \%)$, caudatum (20.9\%), and guinea (13.4\%). The intermediate races durra-caudatum (12.1\%), guinea-caudatum (9.5\%), and durra-bicolor (6.6\%) are common. India, Uganda, and Zimbabwe have all 5 basic and 10 intermediate races (Gopal Reddy et al. 2002).

\subsubsection{U.S.}

The U.S. Department of Agriculture (USDA) began the collection and distribution of sorghum around 1905. The Texas Agricultural Experimental Station was selected as the first station to work on sorghum in collaboration with the USDA (Quinby 1974). A total of 42,221 germplasm accessions are currently maintained at the National Plant Germplasm System (NPGS) (Dahlberg and Spinks 1995).

\subsubsection{Africa}

Ethiopia is a rich center of diversity of sorghum (Rosenow and Dahlberg 2000). The Ethiopian Sorghum Improvement Project (ESIP) began the collection, evaluation, documentation, and conservation of germplasm in the early 1970s, and through the early 1980s had amassed a collection of approximately 5500 accessions (Doggett 1988). It is estimated that through continued research efforts, the germplasm have grown to roughly 8000 collections (Rosenow and Dalhberg 2000). The distinct types of sorghum from Ethiopia are (1) zera zeras, (2) durras, and (3) durra-bicolor derivatives. The zera zeras have been extremely useful in providing germplasm for the improvement of food-type sorghums. Sudanese landrace collections were assembled at Tozi Research Station in Sudan in the 1950s, with the entire collection made available to the Rockefeller Foundation Project in India (Rosenow and Dahlberg 2000). The caudatum race dominates in Sudan, and Sudanese sorghums have been very useful as sources of drought resistance (Rosenow et al. 1999).

\subsubsection{China}

An extensive collection of sorghum landraces has been undertaken in China, with 12,836 germplasm accessions preserved in the National Genetic Germplasm Resources Bank, with 10,414 of these registered as genetic resources (Qingshan and Dahlberg 2001). Of these, 9652 accessions are local varieties, improved varieties, and strains that originated from 28 provinces and municipal and autonomous regions. These accessions are further classified according to use: 9859 sorghum accessions are food types, 394 varieties are for fodder or craft use, and 125 varieties are classified for use in sugar production. Only a limited number of local Chinese cultivars are conserved in sorghum collections at ICRISAT or the U.S. national collection, making these collections important plant genetic resources (Qingshan and Dahlberg 2001).

\subsubsection{Maintenance of Genetic Resources}

The largest sorghum collections are conserved and maintained at ICRISAT, the National Seed Storage Laboratory, Fort Collins, CO, and the USDA-ARS Plant Genetic Resources Conservation 
Unit (PGRCU), Griffin, GA. Several countries maintain their own collections within their national plant genetic resource collections. Major field regeneration takes place at ICRISAT and at the USDA-ARS Tropical Agriculture Research Station, Mayagüez, Puerto Rico (Rosenow and Dahlberg 2000). Collections maintained at ICRISAT are regenerated in the postrainy season by selfing about 20 representative panicles from each line. Seed is harvested in equal quantities from these panicles and mixed to a bulk of about $500 \mathrm{~g}$. The seed is preserved in aluminum cans in a mediumterm storage facility ( $4^{\circ} \mathrm{C}$ and $20 \%$ relative humidity). Freshly rejuvenated accessions with $100 \%$ viability and $5 \pm 1 \%$ seed moisture content are conserved in long-term storage $\left(-20^{\circ} \mathrm{C}\right)$.

\subsubsection{Core Collection}

Sorghum scientists have developed subsets of the total base collection of sorghum in the past; however, these subsets were formed on a location-specific basis and did not represent the true genetic variation within the base collection (Prasada Rao et al. 1995). Therefore, the concept of core collection was developed (Brown 1989). A core collection consists of a limited set of accessions derived from an existing germplasm collection, chosen to represent the genetic and geographical spectrum of the whole collection. The rationale behind a core collection is the maintenance of as much representative genetic diversity as possible within a smaller, more manageable core collection (Dahlberg and Spinks 1995). A core collection was set up at ICRISAT by stratifying the total base collection geographically and taxonomically into subgroups within regions. Accessions in each subgroup were further clustered into closely related groups based on the principal component analysis (PCA) of the agronomic evaluation data. Representative accessions from each cluster were drawn in proportion to the total number of accessions present in that subgroup. Thus, the core collection of 3475 accessions set up at ICRISAT represents approximately $10 \%$ of the total world collection (Prasada Rao and Ramanatha Rao 1995). The core collection is an economical, practical, and effective method for conservation, maintenance, and utilization of the germplasm (Eberhart et al. 1997).

The U.S. set up a core collection of more than 200 accessions from the 42,221 accession base collection at the USDA in Mayaguiez, Puerto Rico. The core collection represents genes for plant height, maturity, drought resistance, pericarp color, greenbug and aphid resistance, and downy mildew resistance (Dahlberg and Spinks 1995).

\subsubsection{Evaluation, Characterization, and Documentation of Genetic Resources}

A prerequisite for the efficient utilization of germplasm is that it must be properly evaluated, characterized, and documented onto a workable retrieval system so that any group of entries carrying any desired characteristics can be easily retrieved and used in breeding programs (Gebrekidan 1982). At ICRISAT, a total of 29,180 sorghum accessions have been characterized for 23 important morphoagronomic characters from the list of sorghum descriptors (IBPGR/ICRISAT 1980) during rainy and postrainy seasons. The range of variabilities available in cultivated races and their wild relatives is extensive, and the extreme types are so different as to appear to be separate species (Table 11.3) (Prasada Rao et al. 1995).

Characterization and passport data are documented using the ICRISAT Data Management Retrieval System (IDMRS) program and have been converted to the System 1032 (a Relational Database Management Software) for faster and more efficient management (Prasada Rao et al. 1995). ICRISAT maintains sorghum germplasm that has been evaluated and known to contain resistance to insect pests such as shoot fly, stem borer, midge, and head bug; resistance to diseases such as grain mold, anthracnose, rust, and downy mildew; resistance to the parasitic weed Striga; and important traits like glossiness, pop, sweet stalk, and scented types.

Approximately $50 \%$ of the total U.S. sorghum germplasm accessions have been characterized for 39 agronomic descriptors, with 21,661 accessions located at the USDA-ARS S-9 site in Griffin, 
Table 11.3 Range of Variation for Selected Traits of Sorghum Accessions Maintained at ICRISAT, Patancheru, India

\begin{tabular}{lll}
\hline \multicolumn{1}{c}{ Descriptor } & & \multicolumn{1}{c}{ Range of Variation } \\
\hline Days to $50 \%$ flowering & 36 & 199 \\
Plant height $(\mathrm{cm})$ & 55 & 655 \\
Pigmentation & Tan & Pigmented \\
Mid-rib color & White & Brown \\
Peduncle exertion $(\mathrm{cm})$ & 0 & 55 \\
Head length $(\mathrm{cm})$ & 2.5 & 71 \\
Head width $(\mathrm{cm})$ & 1 & 29 \\
Head compactness and shape & Very loose stiff branches & Compact oval \\
Glume color & Straw & Black \\
Glume covering & Fully covered & Uncovered \\
Grain color & White & Dark brown \\
Glume size $(\mathrm{mm})$ & 1 & 7.5 \\
100-seed mass $(\mathrm{g})$ & 0.58 & 8.56 \\
Endosperm texture & Completely starchy & Completely corneous \\
Threshability & Easy to thresh & Difficult to thresh \\
Luster & Lustrous & Nonlustrous \\
Subcoat & Present & Absent \\
\hline
\end{tabular}

Source: Prasada Rao, K.E., Gopal Reddy, V., and Stenhouse, J.W., Int. Sorghum Millets Newsl., 36, 15-19, 1995.

GA (Dahlberg and Spinks 1995). Passport and characterization data for U.S. sorghum germplasm accessions are documented on the Germplasm Resources Information Network (GRIN) and are also available through the sorghum curator located in Mayagüez, Puerto Rico.

\subsubsection{Utilization of Genetic Resources}

Only a small fraction of the total available sorghum collection could be fully utilized by breeders at any one time, as crop improvement programs are interested in germplasm that carry special desirable characters that are highly important at any particular point of time (Gebrekidan 1982). Early work on utilization of sorghum germplasm was confined to pure line selection within the cultivated landrace population in Africa and India that resulted in improved cultivars, some of which continue to be widely grown. Selection within dwarf populations was adopted, followed by exploitation of cytoplasmic male sterility that permitted the production of commercial hybrids (Dahlberg et al. 1997). Crossing or backcrossing between adapted introductions and local germplasm has been used to derive improved self-pollinated varieties and parental lines (Prasada Rao et al. 1989). Useful traits, such as increased seed number, larger panicles, greater total plant biomass, drought tolerance, disease resistance, greater plant height, longer maturity, greater leaf area indices, increased green leaf retention, and greater partitioning of dry matter have contributed to increased yield (Miller and Kebede 1984).

Utilization has been primarily limited to agronomically important and, in some cases, wild sources of germplasm. For example, use of zera zera sorghum has become widespread in the development of new, superior hybrids because of superior yield potential and grain quality (Duncan et al. 1991). The classic example of germplasm utilization in sorghum has been the Texas A\&M-USDA Sorghum Conversion Program. To date, 673 converted lines have been released globally (listed in Duncan and Dahlberg 1993; Rosenow et al. 1995; TAES and USDA-ARS 1996).

The successful introgression of resistance to midge and downy mildew has greatly stabilized sorghum production in Australia and Argentina. Considerable opportunities remain for exploiting the collections to improve sorghum production globally. For example, over 340 accessions of sorghum belonging to subgeneric sections Chaetosorghum, Heterosorghum, Stiposorghum, Parasorghum, and Eu-sorghum have been evaluated for resistance to shoot fly at ICRISAT. Seven accessions with high levels of resistance, and some cases close to immunity, were found (Nwanze 
et al. 1995). Transfer of this high level of resistance to cultivated sorghum could greatly improve productivity of late sown crops in Africa and Asia, where shoot fly is a major production constraint (Dahlberg et al. 1997).

Since its establishment in 1972, ICRISAT has made efforts to enhance yield levels and identify resistance sources and use them to develop varieties and seed parents. The major germplasm sources utilized so far in varietal improvement include temperate lines from the U.S., zera zera lines from Ethiopia and Sudan, and some lines of Indian origin. Many stable resistant sources for shoot fly and stem borer have been identified in Africa, India, and the U.S. and have been used in both Indian and ICRISAT programs to confer resistance. ICRISAT developed an improved midge resistant line (ICSV 197 (SPV 694)), while germplasm lines with resistances to multiple diseases, listed in Table 11.1 , are currently being used in breeding programs. ICRISAT used striga resistant germplasm to develop striga-resistant variety SAR 1 . Nearly 1300 germplasm lines and 332 breeding lines were screened for early- and mid-season drought stresses by ICRISAT, identifying eight early-season and terminal drought-tolerant germplasm lines and nine mid-season drought-tolerant germplasm lines.

High-lysine sorghum lines have been developed from Ethiopian germplasm lines. Some promising high-lysine derivatives with shriveled and plump grain were obtained. Several sweet-stalked sorghum lines have been identified with the sweet-stalked trait currently being incorporated into an elite agronomic background. Many lines with desirable forage attributes have been identified, including germplasm with high-quality parameters and low hydrocyanic acid (HCN) and tannin content (Vidyabhushanam et al. 1989).

\subsection{GENETIC VARIABILITY FOR QUALITATIVE AND QUANTITATIVE TRAITS}

Genetic variability in $S$. bicolor has been assessed by researchers at three levels: (1) morphological/phenotyping, (2) biochemical (e.g., allozyme patterns), and, more recently, (3) DNA/nucleotide (variation in nucleotide sequence).

\subsubsection{Morphological/Phenotypic Level}

Genetic variability at the phenotypic level has been assessed using univariate and multivariate statistical tools. Univariate analysis evaluates factors such as range and variance and has been used extensively to evaluate sorghum. A vast reservoir of variability exists for several traits of interest in sorghum (Wenzel 1994; Geng 1994; Haussmann et al. 2001). This germplasm serves as a raw material for the genetic enhancement/prebreeding of varieties and hybrids the world over.

In sorghum, multivariate statistical tools such as Mahalanobi's $D^{2}$ statistic (1936), principal component analysis (Pearson 1901), and factor and canonical analysis (Spearman 1904) have been used to differentiate the genotypes/genetic resources. These methods were first used as a measure of genetic divergence to classify germplasm resources in crops in the Biometrical Genetics Unit of the Indian Agricultural Research Unit during the 1960s (Arunachalam et al. 1998). The potential of these methods was demonstrated in a reclassification of the species variability in the subgeneric section Eu-sorghum based on herbarium specimen measurements that replaced the classification made by Snowden (1936) and Chandrasekharaiah et al. (1969). By using Mahalanobi's D2 statistic and canonical and factor analysis, the genetic diversity within sorghum was evaluated, and a world collection of genetic stocks of sorghum was cataloged and classified by grouping the genotypes into different clusters (Murty and Arunachalam 1967; Murty et al. 1967). In general, divergence analysis can be used to identify suitable parents for realizing heterotic $F_{1} s$, which in turn can be exploited commercially or used to derive superior recombinant inbred lines for further selection. This was demonstrated theoretically by Cress (1966): the higher the genetic divergence between the parents, the higher the heterosis of the $F_{1} s$ would be. Vast literature is available to endorse this 
assumption, although a few contradictory results are also reported. Nevertheless, several researchers have carried out divergence and clustering analysis in sorghum. Ayana and Bekele (1999), Barthate et al. (2000), Kadam et al. (2001), Narkhede et al. (2001), Singh et al. (2001), and Umakanth et al. (2002) are some of the recent researchers who have attempted to assess diversity in sorghum germplasm using multivariate methods.

\subsubsection{Biochemical Level}

Genotypic differences in sorghum can also be determined using isozyme variation that evaluates enzymes with the same catalytic activity, but with different molecular weight and mobility in an electric field. The difference in the enzyme mobility is caused by point mutations resulting in amino acid substitution, so that isozymes reflect the products of different alleles rather than genes (Chahal and Gosal 2002). This principle has been exploited in plant breeding for quantifying genetic variability, characterizing germplasm, and identifying varieties/hybrids. While Arti (1993) and Reddy and Jacobs (2000) have used soluble proteins and isozyme markers, respectively, Schertz et al. (1990) and Aldrich et al. (1992) have used allozymes to assess genetic variability of sorghum germplasm. However, these biochemical markers are not widely used in quantifying the genetic divergence in sorghum, as the number of useful and easily assayable isozymes is a limiting factor.

\subsubsection{DNA Level}

Variation in nucleotide sequence has been exploited to assess the genetic diversity in sorghum germplasm. DNA markers such as restriction fragment length polymorphism (RFLP), random amplified polymorphic DNA (RAPD), sequence characterized amplified region markers (SCARs), simple sequence repeats (SSRs), and others have been used to assess and characterize genetic variability in sorghum genetic resources. Cui et al. (1995), Ahnert et al. (1996), Yang et al. (1996), Menkir et al. (1997), Dean et al. (1999), Ayána et al. (2000a,b), and Thimmaraju et al. (2000) are some of the latest studies where DNA markers have been used to quantify sorghum germplasm diversity. However, this is only illustrative and not meant to be an exhaustive list. RFLP and RAPD have been extensively used, with all studies indicating that DNA markers are effective in detecting the genetic variability in sorghum germplasm.

\subsection{GENETICS AND CYTOGENETICS}

\subsubsection{Genetics}

Knowledge of the nature of genetic control of both qualitative and quantitative characters of agronomic importance is fundamental in systematic and rapid improvement of these traits (House 1985). Excellent reviews on the genetics of various traits are found in Doggett (1988), Murty and Rao (1997), and Rooney (2000). The genetics of traits important to sorghum production are presented in this section.

\subsubsection{Genetics of Morphological and Resistant Traits}

Prominent among those who contributed to the genetics and breeding of sorghum in the early years were G.N. Rangaswamy Ayyangar and his colleagues, Rao (1972) in India, and J.R. Quinby and his colleagues in the U.S. (House 1985). They studied the inheritance of various morphological characters following Mendelian segregation. Quinby and Karper (1954) have shown that four recessive nonlinked brachytic dwarfing genes control height. Quinby et al. (1973) have shown that duration of growth and floral initiation are controlled by four loci, both dominant and recessive alleles at the 
Table 11.4 Genetics of Disease Resistance in Sorghum

\begin{tabular}{lll}
\hline \multicolumn{1}{c}{ Disease } & \multicolumn{1}{c}{ Genetic Nature } & Number of Alleles \\
\hline Kernel smut & Incomplete dominant & 3 \\
Head smut & Dominant & - \\
Milo disease & Susceptibility is partially dominant & 1 \\
Anthracnose & Dominant, cytoplasm not significant & 1 \\
Rust & Dominant & 1 \\
Leaf blight & Susceptibility (in sudangrass) is dominant & 1 \\
Stay-green trait & Dominant at least with E 36-1 hybrids & - \\
Downy mildew & Dominant & $>2$ \\
\hline
\end{tabular}

Source: House, L.R., $\boldsymbol{A}$ Guide to Sorghum Breeding, 2nd ed., International Crops Research Institute for the Semi-Arid Tropics, Patancheru, India, 1985.

maturity loci. Most tropical landraces/varieties are dominant at all four loci (four major genes Mal, $M a 2, M a 3$, and $M a 4$ with 13, 13, 16, and 12 different alleles, respectively, influencing days to maturity), but a recessive allele at the Mal.locus will cause them to be much less photoperiod sensitive and apparently less responsive to temperature variations, i.e., result in temperature zone adaptation. Other traits that received major attention were plant, glume, and grain color traits.

With increased interest in economic traits, including resistance to various yield-limiting factors, and with the development of novel procedures in quantitative genetics, many studies focused on the genetics of resistance to various traits and grain yield. The genetics of resistance to most diseases caused by fungi, bacteria, and viruses are in general simple inheritance of dominant alleles. Table 11.4 details genetics of the resistance to major diseases of sorghum. Grain mold resistance, on the other hand, is complex, with resistant (red-grained) hybrids produced by crossing susceptible redgrained female parents and white-grained restorer lines. It was established that flavan 4-ols at moderate levels in red-grained restorers were not sufficient enough to cause resistance in the parental lines, but were inherited in the $F_{1}$ hybrids and complemented to result in resistant hybrids (Reddy et al. 1992).

In contrast to diseases, the genetics of insect resistance is complex. Four insects are recognized as important pests throughout Asia, Africa, and India: shoot fly, stem borer (Chilo spp. and Busseola spp.), midge, and head bug (Calocoris spp.). Nonpreference mechanism is the predominant form of resistance and is quantitatively inherited mainly through additive gene action (Sharma et al. 1977).

Rana et al. (1980) reported that the $F_{1}$ is almost intermediate between the two parents for shoot fly resistance; however, resistance was found to be partially dominant under low to moderate shoot fly pressures. Resistance to stem borer is conferred by both tolerance and antibiosis, with primary damage explained by additive (A) and $\mathrm{A} \times \mathrm{A}$ interactions, and secondary damage controlled by $\mathrm{A}$ and nonadditive gene interactions (Rana and Murty 1971; Jotwani 1976). Resistance to both midge and head bug are predominantly under the control of additive gene action (Sharma et al. 1996; Ratnadass et al. 2002).

\subsubsection{Male Sterility}

Two types of male sterility are widely used in sorghum improvement programs: (1) genetic male sterility (GMS) and (2) cytoplasmic-nuclear male sterility (CMS).

\subsection{Genetic Male Sterility}

Genetic male sterility is expressed in sorghum in many ways. In all cases, a recessive allele in homozygous condition (designated with alleles $m s_{1}$ to $m s_{7}$ and al) confers male sterility. Genetic male sterility is discussed in detail in Doggett (1988), Murty and Rao (1997), and Rooney (2000). 
Table 11.5 Male Sterility-Inducing Cytoplasms of Sorghum

\begin{tabular}{llll}
\hline Cytoplasm & & \multicolumn{2}{c}{ Source Line } \\
\cline { 3 - 4 } Fertility Group & Identity & & Race Origin \\
\hline$A_{1}$ & Milo & $\mathrm{D}$ & \\
& IS $6771 \mathrm{C}$ & $\mathrm{G}-\mathrm{C}$ & India \\
& IS $2266 \mathrm{C}$ & $\mathrm{D}$ & Sudan \\
& IS $6705 \mathrm{C}$ & $\mathrm{G}$ & Burkina Faso \\
& IS $7502 \mathrm{C}$ & $\mathrm{G}$ & Nigeria \\
& IS $3579 \mathrm{C}$ & $\mathrm{C}$ & Sudan \\
& IS $8232 \mathrm{C}$ & (K-C)-C & India \\
& IS $1116 \mathrm{C}$ & $\mathrm{G}$ & India \\
& IS $7007 \mathrm{C}$ & $\mathrm{G}$ & Sudan \\
$A_{2}$ & IS $1262 \mathrm{C}$ & $\mathrm{G}$ & Nigeria \\
& IS $2573 \mathrm{C}$ & $\mathrm{C}$ & Sudan \\
$A_{3}$ & IS $2816 \mathrm{C}$ & $\mathrm{C}$ & Zimbabwe \\
& IS $1112 \mathrm{C}$ & $\mathrm{D}-(\mathrm{DB})$ & India \\
$A_{4}$ & IS $12565 \mathrm{C}$ & $\mathrm{C}$ & Sudan \\
$\boldsymbol{A}_{\mathrm{E}}$ & IS $6882 \mathrm{C}$ & $\mathrm{K}-\mathrm{C}$ & U.S. \\
$A_{5}$ & IS $7920 \mathrm{C}$ & $\mathrm{G}$ & Nigeria \\
$A_{6}$ & IS 7218 & & Nigeria \\
& IS $112603 \mathrm{C}$ & $\mathrm{G}$ & Nigeria \\
& IS $7506 \mathrm{C}$ & $\mathrm{B}$ & Nigeria \\
& IS $1056 \mathrm{C}$ & $\mathrm{D}$ & India \\
& IS $2801 \mathrm{C}$ & $\mathrm{D}$ & Zimbabwe \\
& IS $3063 \mathrm{C}$ & $\mathrm{D}$ & Ethiopia \\
\hline
\end{tabular}

Source: Schertz, K.F., in Use of Molecular Markers in Sorghum and Pearl Millet Breeding for Developing Countries, Proceedings of an ODA Plant Sciences Research Conference, J.R. Witcombe and R.R. Duncan, Eds., Norwich, U.K., March 29-April 1, 1993, pp. 35-37. With permission.

\subsection{Cytoplasmic-Nuclear Male Sterility}

The discovery of the male sterility resulting from the interaction of cytoplasmic and nuclear genes by Stephens and Holland (1954) laid the foundation and revolutionized the development of hybrid cultivar and hybrid seed production technology. The original source of the cytoplasm was the milo race, which induced male sterility in the nuclear background of the kafir race, and is designated as the $A_{I}$ cytoplasm. Since then, several sources and types of male sterile-inducing cytoplasms $\left(A_{I}\right.$ to $\left.A_{6}\right)$ have been discovered and are reported in Table 11.5. In all these cytoplasms, a single/oligo recessive gene in the nucleus and sterile cytoplasm induces male sterility. These male sterile cytoplasms are differentiated based on the inheritance patterns of their fertility restoration, which is unclear, but dependent on the specific cytoplasm and nuclear combinations. Fertility restoration is controlled by a single gene in some combinations (e.g., $A_{l}$ ) but is controlled by two or three genes when the same nuclear genotype interacts with a different cytoplasm (Schertz 1994).

Although diverse male sterile cytoplasms have been identified, by far, only the milo cytoplasm $\left(A_{I}\right)$ male sterility system is widely used because the hybrids based on this cytoplasm produce sufficient heterosis (20 to $30 \%$ ) over the best available pure lines in sorghum. Although $A_{2}$ cytoplasm is as good as $A_{1}$ cytoplasm for mean performance as well as heterosis for economic traits such as grain yield, days to $50 \%$ flowering, and plant height, it is not popular, as the anthers in $A_{2}$ male steriles, unlike the $A_{I}$ male steriles, mimic the fertile or maintainer lines and lead to difficulties in monitoring the purity of hybrid seed production. Milo restorers need to be diversified in a guinea background to further enhance the yield advantage in hybrid development. So, there is a need to identify and breed for high-yielding nonmilo cytoplasm restorers. Based on $A_{2}$ CMS systems, only one hybrid, Zinza 2, has been developed and released in China for commercial cultivation (Liu Qing Shan et al. 2000). 


\subsubsection{Cytogenetics}

Sorghum bicolor has a haploid chromosome number of 10 , and it is classified as a diploid ( $2 \mathrm{n}$ $=2 \mathrm{x}=20)$. Most species within Sorghum are diploid $(2 n=20)$, but several species, most notably Sorghum halapense, are tetraploid $(2 n=4 x=40)$. As the basic chromosome number in the Sorghastrae is five, it has been hypothesized that sorghum may be of tetraploid origin (Rooney 2000). Earlier studies on the meiotic chromosome pairing analysis did not provide evidence for the tetraploid origin of S. bicolor (Brown 1943; Endrizzi and Morgan 1955), and the information on the existence of homologous segments in the chromosomes of S. bicolor is poor; therefore, the chromosomes were regarded as distinct. Recent studies provide limited evidence about tetraploid origin of sorghum (Gomez et al. 1998). The molecular marker mapping studies of the genome by Chittenden et al. (1994), Pereira et al. (1994), and Dufour et al. (1996) demonstrated duplicated loci on the map, suggesting that sorghum has tetraploid origin. However, Subudhi and Nguyen (2000) contended that these evidences of tetraploidy are not satisfactory. They argued that in both analyses, the duplicated loci found on the mapped genome are only to an extent of 8 and $11 \%$, respectively (Chittenden et al. 1994; Dufour et al. 1996). In a recent study, Peng et al. (1999) concluded that there is not enough evidence for tetraploidy origin of sorghum. Therefore, the cultivated sorghum could be considered a diploid from the perspective of genome organization (Subudhi and Nguyen 2000).

\subsubsection{Karyotype}

Analysis of sorghum chromosomes has been difficult, due to similarities in chromosome size and structure (Doggett 1988); nevertheless, several researchers have attempted to describe the karyotype of sorghum (Garber 1950; Celarier 1959; Gu et al. 1984; Mohanty et al. 1986; Yu et al. 1991).

\subsubsection{Euploid Variation}

Euploid variants such as haploids, triploids, and tetraploids occur naturally and can be induced. Autotetraploid sorghums have an increased grain size, which sparked interest in their development for grain production (Doggett 1962). The initial limitation in autotetraploid development was the high level of sterility; however, selection for improved fertility was successful, with resulting fertility levels near that of diploids (Doggett 1962; Luo et al. 1992). However, further research in this direction stalled, resulting in the nonrealization of tetraploid sorghum for grain production.

\subsubsection{Aneuploid Variation}

Aneuploids are organisms with more or less than an integral multiple of the haploid chromosome number. The most common form of aneuploidy observed in sorghum is trisomy, followed by translocation.

\subsubsection{Apomixis}

Apomixis in sorghum occurs when the embryo forms by apospory from a somatic cell in the nucellus. About $25 \%$ of the progeny developed apomictically can occur at a significantly higher percentage (Hanna and Schertz 1970; Rao and Murty 1972; Murty and Rao 1977). In most cases, apospory is the primary mechanism of apomixis in sorghum, although diplospory may occur (Murthy et al. 1979). Apomixis provides a mechanism to perpetuate a high-performing hybrid through self-pollination. Obligate apomixis is necessary to develop such a system, but all the reports of apomixis in sorghum involve only facultative apomixis, and efforts to increase the frequency of 
apomicts have not been successful (Reddy et al. 1980). To utilize facultative apomixis, the use of "vybrids" has been proposed (Murthy 1986).

\subsection{SORGHUM IMPROVEMENT}

\subsubsection{Environmental Response Characteristics}

Sorghum originated near the equator in northeastern Africa and is sensitive to day length and temperature (Miller 1982). It is classified as a short-day type with a critical photoperiod of 12 hours; however, some cultivars are classified into groups with higher critical photoperiods, including a class that is photoperiod insensitive (Miller et al. 1968). The sorghum plant differentiates from vegetative to reproductive growth when the day length becomes short (12 hours) and the rains diminish in tropical areas of Africa and India. At ICRISAT, it was shown that some high-yielding cultivars (CSH 1 and ICSV 112) with wide adaptability did not delay in flowering during rainy season, even when exposed to a day length of 17 hours (Alagarswamy, personal communication).

Information on the temperature effects on sorghum is scanty. Germination base temperature can differ within species and may vary from 4.6 to $16.5^{\circ} \mathrm{C}$. Lines and hybrids designated as tropically adapted have lower germination base temperatures than the lines and hybrids designated as temperately adapted (Thomas 1980). High-yielding hybrids developed in temperate zones but grown in tropical environments have shown lower yields (Miller 1982).

\subsubsection{Conversion Programs}

Sorghum is a native of tropical Africa, with most of the species diversity found in the indigenous sorghums in tropical Africa and Asia. Most of these sorghums are landraces that do not flower in temperate zones in countries such as the U.S. Growing these photoperiod-sensitive lines as a summer crop in these temperate regions (when the day length is longer than 13 hours) makes it difficult to evaluate and use them for breeding. A dramatic decline in the expression of many growth-related characteristics is observed when photoperiod-sensitive germplasm is grown under continuous short days. Thus, photoperiod-insensitive germplasm has found much wider use in breeding programs (Rai et al. 1999). Many breeders recognized the positive correlation between height and yield in sorghum and developed lines as tall as possible to withstand the hazards of production (Miller 1982). However, maximum productivity is generally seen at about 1.75 to $1.80 \mathrm{~m}$ height and flowering at 68 to 70 days (Rao and Rana 1982). Height and maturity are controlled by four to eight genes, which when selected for can obtain lines with the desired height and maturity.

The major objective of the conversion program was to provide new sources of genetic diversity of exotic sorghums that have desirable plant height and maturity that are usable in sorghum improvement programs in Texas (Rosenow and Dahlberg 2000). The scheme essentially involved backcrossing early and dwarf $\mathrm{F}_{3} \mathrm{~s}$ at Mayaguez, Puerto Rico (selected from $\mathrm{F}_{2} \mathrm{~s}$ grown at Texas A\&M), to the landrace. This was repeated four times before the final cross was made at Mayaguez using the landraces as the female to capture the landrace cytoplasm. This program had nearly 1279 lines that contributed to the breeding programs, not only in the U.S. but also in India and other places (Miller 1980). BTx 622 and BTx 623 are examples of lines that have made significant contributions to various seed parent development programs in several parts of the world (Reddy and Stenhouse 1994b; Rooney and Smith 2000).

In 1979, ICRISAT initiated a program to convert tall, late-flowering zera zera landraces (from the Ethiopia-Sudan border) and kauras and guineenses (from Nigeria). Several short and earlyflowering lines were selected, with the converted lines of a height and maturity able to be cultivated under tropical, short-day conditions, and in temperate zones such as the U.S. The converted lines have been very useful in enhancing the use of exotic sorghum germplasm, broadening the genetic 
diversity, and providing new sources of desirable traits to sorghum researchers (Rosenow et al. 1997).

\subsubsection{Breeding Concepts and Breeding Material}

Breeding methods in sorghum improvement at various centers have taken into account the geographical mandate of individual research organizations, their materials and manpower resources, and short-term and long-term goals with respect to increasing productivity and genetic diversification (Rai et al. 1999). Breeding methods used in sorghum improvement are those developed for self-pollinated crops such as pure line selection, pedigree breeding, backcross breeding, population improvement, and hybrid breeding.

\subsubsection{Breeding Concepts}

Several breeding concepts are employed to utilize germplasm to develop high-yielding varieties and hybrid parents with resistance to biotic and abiotic stresses. Tropical germplasm are important as sources of dominant alleles for yield and plant height, while temperate germplasm are important for dominant alleles for earliness/maturity. The use of tropical $\times$ temperate crosses has produced several high-yielding varieties with desirable plant height (2.0 to $2.5 \mathrm{~m}$ ) and maturity (100 to 110 days) (Rao and Rana 1982). Exotic germplasm are rich sources of genes for sorghum breeding, with crosses of exotic $\times$ exotic parents generally the most rewarding compared with local $\times$ local crosses (House et al. 1997). The most common breeding concept employed to introgress important traits is backcrossing, and it is most effective for simply inherited qualitative traits.

The type of restorer line used in breeding significantly impacts heterosis, or vigor, in the resulting hybrids. Guinea restorer lines contributed to the highest heterosis and grain yield per se in hybrids, followed by caudatum restorer lines. It was proposed that further gains can be made by making use of guinea sorghums after overcoming accompanying problems such as clasping of glumes to the grain in hybrids of caudatum-kafir male steriles and guinea restorers (Reddy and Prasada Rao 1993). Postrainy season adapted landrace germplasm possess excellent adaptive characteristics for the prevalent moisture-limiting conditions, with resulting landrace hybrids containing almost all the characteristics of the landraces preferred by farmers, as well as $15 \%$ superiority in grain yield over cultivated landraces (ICRISAT 1995).

Breeding methods for drought resistance and yield potential have been established by Reddy (1986) by selecting breeding materials for specific traits, such as emergence under crust, seedling drought recovery, and grain yield under drought-prone and yield potential areas for early-stage drought; drought recovery and grain yield under drought-prone and yield potential areas under midseason drought; and stay-green, nonlodging, and grain yield under drought-prone and yield potential areas for terminal drought.

To date, most sorghum released globally were derived from the pedigree breeding program rather than from the population improvement programs at ICRISAT, indicating that for a short specific adaptation, pedigree selection appears to be more appropriate. It is therefore evident that the targeted gene pool approach is appropriate for a program that aims at a broad geographic mandate (Reddy et al. 2004a). Breeding schemes involving simultaneous selection for resistance and grain yield and converting the maintainer selections into male sterile lines have been used effectively to develop male sterile lines for resistance to pests and diseases in the shortest possible period of four years (Reddy et al. 2004a).

Breeding for insect resistance targets multiple traits. For stem borer resistance, the independence of antibiosis and the difference in patterns of inheritance of resistance to flower and peduncle damage and dead heart formation must be considered. The traits foliar and stem damage and the percentage of dead hearts were targeted with stem borer-resistant genotypes identified (Singh and Rana 1994). For shoot fly, the most important factor is to select for resistant germplasm in the 
season for which the material is intended (Jayanthi Kamala 1997). In selecting for resistance and increased yield, a multiple selection approach is employed with resistance selected on a family basis, and then selecting individuals within the resistant family for yield (ICRISAT 1995). In combining resistance characters that are simply inherited with grain yield, multiple crosses (three or four way) are as effective as single crosses. However, the selection for resistance of quantitatively inherited traits, such as resistance to stem borer or shoot fly, is not effective in four-way crosses (Reddy 1993).

\subsubsection{Breeding Materials}

The breeding materials so far exploited rather extensively in sorghum breeding programs in India, other tropical areas of the world, and the southern U.S. are derivatives of the zera zera group (Reddy and Stenhouse 1994a; Rosenow and Dalhberg 2000). Extensive use of the zera zera group of converted sorghums has contributed to produce disease resistance, yield potential, and grain quality of U.S. hybrid sorghum (Rosenow and Dalhberg 2000). Sorghum breeders in both public and private sectors throughout the world have been making extensive use of released, partially and completely converted, tall, late-maturing photoperiod-sensitive tropical exotic sorghum for conversion into short, photoperiod-insensitive, early types (Duncan et al. 1991). In the U.S., kaura, an African introduction, a source of yellow endosperm, was extensively used in sorghum improvement prior to the development of the conversion programs (Rosenow and Dalhberg 2000).

In India, zera zera lines have been extensively used to develop hybrids. This coupled with the selection for high grain yield, white grain color, medium grain mass, and optimum plant height and maturity resulted in materials looking alike, and this necessitated diversification (Reddy and Stenhouse 1994a).

\subsubsection{Adaptation and Productivity Enhancement}

Most of the varieties before 1960 in India were the result of pure line selection. The hybridization program was limited to improving grain yield and stalk juiciness. Breeders in the U.S. also aimed to improve lines for grain yield in the given location with short height suitable for combined harvest. By altering a maturity gene, grain yield could be enhanced substantially (Quinby and Karper 1946; Maunder 1972).

The discovery of genetic male sterility in sorghum opened up opportunities for recombination. Of the several genes reported to induce genetic male sterility, only two genes were widely used in population improvement, as they are stable over a range of environments (Reddy and Stenhouse 1994a; Murty and Rao 1997). This, in combination with various mating systems and reciprocal recurrent selection methods in exploiting additive (A), $\mathrm{A} \times \mathrm{A}$ and some epistatic genetic variations led many breeders to propose/take up the population improvement methods in the 1960s (Comstock and Robinson 1952; Doggett 1972; Eberhart 1972; Maunder 1972). These breeding enhancements led to the development of several populations in East and West Africa supported by funding from the International Development Research Council (IDRC) (Doggett 1972; Gardner 1972).

The sorghum improvement program at ICRISAT was initiated in 1972 with population improvement using the male sterility-inducing $m s_{3}$ gene following recurrent selection procedures to breed for wider adaptability. By 1980, the emphasis shifted to specific adaptation, and several specific disease- and pest-resistant gene pools with $m s_{3} / m s_{7}$ male sterile genes, following elaborate half$\mathrm{sib} / \mathrm{s}_{1} / \mathrm{s}_{2}$ testing procedures, were developed. Since the $1990 \mathrm{~s}$, trait-specific gene pool improvement using male sterile genes following simple mass selection alternating with recombination methods has become a corner stone in the development of diverse breeding materials (Reddy et al. 2004a). To date, 19 populations have been developed at ICRISAT using $v$ and $m s_{7}$ genes, into which 501 diverse germplasm accessions were introgressed. 
Hybrids have distinct yield superiority (by at least $48 \%$ ) and wide adaptability compared to the best available varieties in India and the U.S. (Maunder 1972; Rao 1972). Due to their wide adaptability, the All India Coordinated Sorghum Improvement Project (AICSIP) formulated the national policy of releasing hybrids for more than one state in India (Murty 1991, 1992; Murty and Rao 1997). Thus, the concept of wide adaptability of hybrids supported by the movement of the materials across continents was firmly established by the year 1985 .

It was realized quite quickly that the ICRISAT-bred materials, although widely adaptable, did not adapt to drought environments in West Africa, or in high-altitude areas of Ethiopia, Kenya, etc. The ICRISAT drought resistance breeding program clearly established that drought is highly specific and that breeding for drought resistance therefore depends upon the stage of the crop at which the drought occurs, inferring that breeding for the traits that contribute to specific drought resistance should be carried out to realize further productivity gains in the target regions (Reddy 1986). This realization led to the establishment of different regional centers by ICRISAT in Africa, such as Niamey, Niger; SADC-ICRISAT, Bulawayo, Zimbabwe; and ICRISAT Sorghum and Pearl Millet East African Program, Nairobi, Kenya; as well as the Latin American Sorghum Improvement Program, El Baton, Mexico (Reddy and Stenhouse 1994a). These programs led to the release of head bug-resistant varieties across several countries.

The development and commercial cultivation of hybrid sorghums led to the improvement in grain yield by over 300\% from 1950 to 1990 in the U.S. Later improvements were in terms of smaller yield increments, and enhanced disease and insect resistance and grain quality (Rooney and Smith 2000). Introduction of several seed parents of hybrid grain sorghum from the U.S. paved the way for hybrid development in Australia with several hybrids released during the 1960s. Maximum yield advance due to breeding during the 30 years since 1960 varied from 0.3 to $0.6 \%$ per year. However, the grain yield of subsequently released hybrids in 1986 was equal to the boot midge-susceptible hybrids in the absence of midge in Queensland (Henzell 1992). A further increase in yield was evident in nonsenescent hybrids AQL 40/RQL 36 and AQL 41/RQL 36, which averaged 111.4 and $113.1 \%$, respectively, of the mean yield of three check hybrids (Texas 610SR, pride, and E57+). The increased yield potential of these hybrids was due to their late maturity and therefore greater biomass (Miller 1992).

Exploitation of heterosis was the main method of yield improvement in China. Through a program of selecting the best introduced seed parents, and then evaluating Chinese-bred pollinators, a series of hybrids were developed beginning in the 1970s. A progressive increase in yield (3.75 $t$ $\mathrm{ha}^{-1}$ in 1992-94 compared to $1.01 \mathrm{t} \mathrm{ha}^{-1}$ in 1962--64) was accompanied by an improvement in quality traits. The increase in yield due to utilization of hybrids is estimated at 30 to $40 \%$, with the remaining improvement being due to better cultivation conditions (Zhen Yang 1997).

\subsubsection{Trait-Based Breeding}

\subsubsection{Grain Yield and Adaptation}

Breeding for high and stable grain yield with an improved harvest index continues to gain the top priority in sorghum (Rai et al. 1999). The use of adaptive trait breeding has been successful in achieving stable and productive cultivars. The identification and utilization of such traits as nonsenescence, control of apical dominance, green bug and midge resistance, lodging resistance, tillering control, and resistance to downy mildew, head smut, foliar, and other diseases, have led to improvement in yield and its stability in many sorghum production areas (Miller et al. 1997).

\subsubsection{Forage and Feed}

Forage is defined as "food for animals especially when taken by browsing or grazing" (Webster's 1986). Sorghum grown for forage in the tropics is often tall ( 2 to $3 \mathrm{~m}$ ) but can be the very same 
dwarf hybrid grown for grain production and may or may not include grain fraction of the plant (Pedersen and Fritz 2000). However, from a definition point of view, the forage sorghum includes cultivars ranging from silage sorghum hybrids to varieties to Sorghum sudanense $(2 n=10)$ and sorgo-sudangrass hybrids to sudangrass varieties $(2 \mathrm{n}=10)$ and hybrids (Kalton 1988). The uses of forage sorghum varies; in India it is commonly used as green fodder in northern states, and as stover after the grain harvest in southern states (House et al. 2000), while in the U.S., it is primarily used as silage, and to a limited extent, as pasture and hay for livestock (Kalton 1988).

Forage sorghums make efficient use of soil moisture by resorting to a semidormant state during stress, with a rapid response to moisture and a wide range of adaptability (Hanna and Cordona 2001). They also make efficient use of soil fertility by producing a higher number of tillers and biomass (Ahlrichs et al. 1991). Owen and Moline (1970) proposed a general classification of the forage sorghums based upon their use: (1) pasture using Columbus grass (Sorghum almum); (2) pasture and green chop or hay using Johnson grass (Sorghum halepense, $2 n=40$ ), sudangrass ( $S$. sudanense, $2 \mathrm{n}=10$ ), or sudangrass hybrids; (3) green chop or hay using sorghum-sudangrass hybrids; (4) silage using sorgos and canes; and (5) dual purposes (i.e., for production of grain and stover) using grain sorghums or single- or two-gene dwarf sorghums.

The primary objective of most forage breeding programs was forage yield (Kalton 1988). However, after 1988, efforts were directed toward improving quality traits. Although most forage quality traits like in vitro dry matter digestibility (IVDMD), crude protein (CP), neutral detergent fiber (NDF), and acid detergent fiber (ADF) appear to be quantitatively inherited, several simply inherited qualitative traits such as plant height, maturity, juiciness, sweetness, plant color, staygreen trait, etc., have a significant impact on forage quality (Bramel-Cox et al. 1995; Pederson 1997). Improvements in forage quality hold the greatest opportunities in improving forage sorghum (Hanna and Cordona 2001).

Owen and Moline (1970) concluded that the stage of maturity was the most important factor influencing the quantity and quality of forage produced. From heading to the ripe-seed stage, forage sorghums generally declined in protein content, crude fiber, and ash. An increase in lignin content followed by variable sugar content was observed with stage of maturity in grain sorghum. The sudangrass and sorghum-sudangrass hybrids were the most affected by maturity, with reduced protein content.

Four basic height genes are related to the dwarfing of the sorghum plant (Quinby and Karper 1954). It has been shown that dwarf sorghums containing one, two, or three of these dwarfing genes have no difference in leaf percentage; however, the percentage stalk vs. head was significantly affected. The one-dwarf type had $75 \%$ stalks and $7 \%$ heads, the two-dwarf type had $56 \%$ stalks and $23 \%$ heads, and three-dwarf type had $36 \%$ stalks and $43 \%$ heads (Gourley and Lusk 1978).

The usefulness of forage incorporated into diets of ruminants and forage used as biomass for biological conversion to liquid fuels is limited by the quantity of lignin present (Cherney et al. 1991). Hence, there is worldwide interest in improving the quality of forage through breeding to reduce or alter lignin content by incorporating brown mid-rib (bmr) trait in plants (Cherney 1990). $B m r$, a single-gene trait, has the greatest forage quality, and Kalton (1988) recognized that great improvement was possible with increased incorporation of the $b m r$ trait into all types of forage sorghum. Brown mid-rib mutant, discovered in maize in 1924 by Jorgenson (1931), was later induced in sorghum (Porter et al. 1978). Lignin concentrations in the $b m r$ mutant are consistently lower than their normal counterparts in sorghum, while in vitro digestibility of $b m r$ genotypes has been consistently higher than normal. Brown mid-rib mutant, differing in quantity and quality of lignin from normal genotypes, offers an opportunity to increase the overall digestion of plant fiber, which is a major constituent of forage crops, comprising 30 to $80 \%$ of their dry matter (Cherney et al. 1991). Several sorghum lines with high biomass were selected for the $b m r$ trait at ICRISAT, with several white-grained B-lines, a red-grained B-line, and two red-grained varieties identified.

Stay-green is another simply inherited trait that is known to improve forage quality. Stay-green, governed by a recessive allele, not only slows down senescence but also arrests the decline in 
protein content of the aging leaves (Humphreys 1994). It also contributes to terminal drought and charcoal rot resistance (Rosenow and Clark 1995). Information on stay-green hybrid parental lines developed at ICRISAT is available at http:/www.icrisat.org/text/research/grep/homepage/sorghum/breeding/main.htm.

Kalton (1988) proposed that an ideal silage sorghum would include traits such as red seed, yellow endosperm, absence of testa layer, brown mid-rib, tan plant color, juicy stalk, moderate to low hydrocyanic acid (HCN), high IVDMD, good protein content, good leafiness, and green leaf retention.

ICRISAT has developed a strong forage sorghum improvement program that has developed a diversified set of hybrid parents, grain and dual-purpose varieties, and a population improvement program to improve sudangrass sorghums. Breeding has focused on high biomass, grain yield and stem sugar content, $b m r$ lines, and grain types that tiller under stress conditions such as drought and stem borer resistance (Reddy et al. 1994). This program has resulted in the production of several lines with high tillers, and the identification of sweet-stalk lines, useful for developing ratoon and multicut sweet sorghum and dual-purpose and forage varieties and hybrids.

The objectives in the use of sorghum grain for livestock feed are different in ruminants (cattle, sheep, and goats) than in nonruminants (swine, poultry, and fish). In ruminants, the rumen microflora can upgrade poor-quality proteins and nonprotein nitrogen to the protein quality of the microflora itself, making protein levels less important, and as such, sorghum grain is primarily a source of starch. In nonruminants, the protein quality and quantity of sorghum grain are important because in sorghum-based diets it can contribute more than one third of the dietary crude protein for chicks and more than one half of the dietary crude protein for growing and finishing pigs (Bramel-Cox et al. 1995; Hancock 2000).

Of the several fairly simply inherited traits, such as pericarp color and endosperm color, type and texture differences in endosperm characteristics affect nutritional value in contrast to pericarp color (McCollough et al. 1972; Noland et al. 1977). Myer and Gorbet (1983) compared sorghum grain with waxy and normal starch types and low, medium, and high tannin content in nursery pigs. As tannin content increased, rate and efficiency of grain decreased, but sorghum with the waxy starch type was no better nutritionally than sorghum with normal starch type. There was a lack of improvement in energy digestibility and utilization in swine fed with floury and waxy endosperm sorghum, with the very soft or floury sorghums also having reduced yield and poor weathering ability.

Selection for improved in vitro protein (digestibility of pepsin) was found to be associated with lower yield and late maturity; however, the use of in vitro digestibility in conjunction with yield and maturity date has the potential to genetically improve grain sorghum as a feed grain for livestock, even though the environment will still have a major effect on nutritional quality. Unlike selection for floury and waxy endosperm texture, a selection index involving in vitro digestibility, grain yield, and maturity would result in genetic material to breed hybrids with acceptable yield, maturity, and improved nutritional value (Bramel-Cox et al. 1990, 1995).

\subsubsection{Resistance to Foliar, Stem, and Head Feeding Insects}

Foliage pests of grain sorghum in the U.S. are green bug (Schizaphis graminum), yellow sugarcane aphid (Sipha flava), chinch bug (Blissus leucopterus), fall armyworm (Spodoptera frugiperda), corn leaf aphid (Rhopalosiphum maidis), and Banks grass mite (Oligonychus pratensis). Biotype development has been a problem only with green bug, the key foliage pest of sorghum in the U.S. Foliage pests of grain sorghum outside the U.S. are shoot fly (Atherigona soccata), spotted stem borer (Chilo partellus), and sugarcane aphid (Melanaphis sacchari) (Peterson et al. 1997). Midge (Contarinia sorghicola) is a serious head pest common in India, eastern Africa, and Australia, with head bug (Eurystylus oldi) another important pest in India and western and central Africa. 

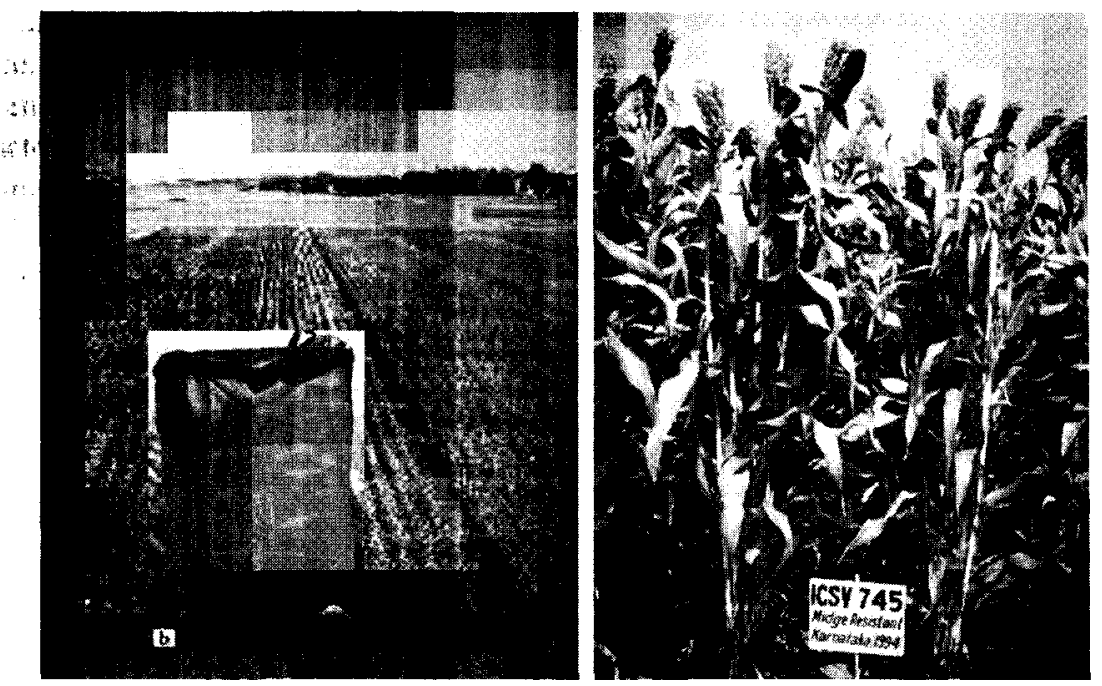

Figure 11.2 (See color insert following page 114.) (Left) Technique to screen sorghum lines resistant to midge. (Right) An improved sorghum cultivar resistant to midge produced by ICRISAT.

The lack of elite insect-resistant varieties and hybrids is due to low resistance levels when transferred into agronomically improved sorghum. When resistance is high, progenies are agronomically undesirable (Nwanze et al. 1995). In addition, resistance to some insects is quantitatively inherited and difficult to incorporate into elite, high-yielding varieties or hybrids (Peterson et al. 1997).

Development of improved germplasm or varieties resistant to shoot fly, stem borer, and midge is the example for the success of conventional breeding programs in Africa and India (Sharma 1993). Use of wild sorghums Sorghum versicolor and Sorghum arundinacium to obtain qualitatively different sources of resistance is the future objective. Absolute resistance to shoot fly was noticed in wild relatives Sorghum dimidiatum and Sorghum australiense, with efforts currently under way to exploit and introgress these using molecular markers.

Several midge-resistant varieties and hybrid parents have been developed at ICRISAT using pedigree selection and backcross techniques; however, these are mostly based on a single source of resistance that loses its resistance at the high altitudes and low temperatures of eastern Africa. In western and central Africa, advanced midge-resistant lines bred at Patancheru are crossed to locally adapted elite materials to obtain improved midge-resistant cultivars (Figure 11.2).

Breeding efforts for resistance to stem borer by ICRISAT and western and central Africa are focused on $C$. partellus and $B$. fusca, with several stem borer-resistant male sterile lines, pollinators, and varieties developed. In western and central Africa, a random mating population with sources of resistance to $B$. fusca and adapted high-yielding lines are being developed and pursued through recurrent selection procedures.

\subsubsection{Disease Resistance}

Table 11.2 lists major diseases. Disease management through genetic manipulation has been the most effective means of reducing losses in many crop species. However, managing all diseases by genetic means is neither feasible nor possible (Thakur et al. 1997). Breeding for host plant resistance is one of several methods of protecting the crop. Therefore, before a resistance breeding program begins, it must be determined that (1) the disease is of sufficient economic importance, (2) sufficient information is available on the nature of the host-pathogen system and on screening 

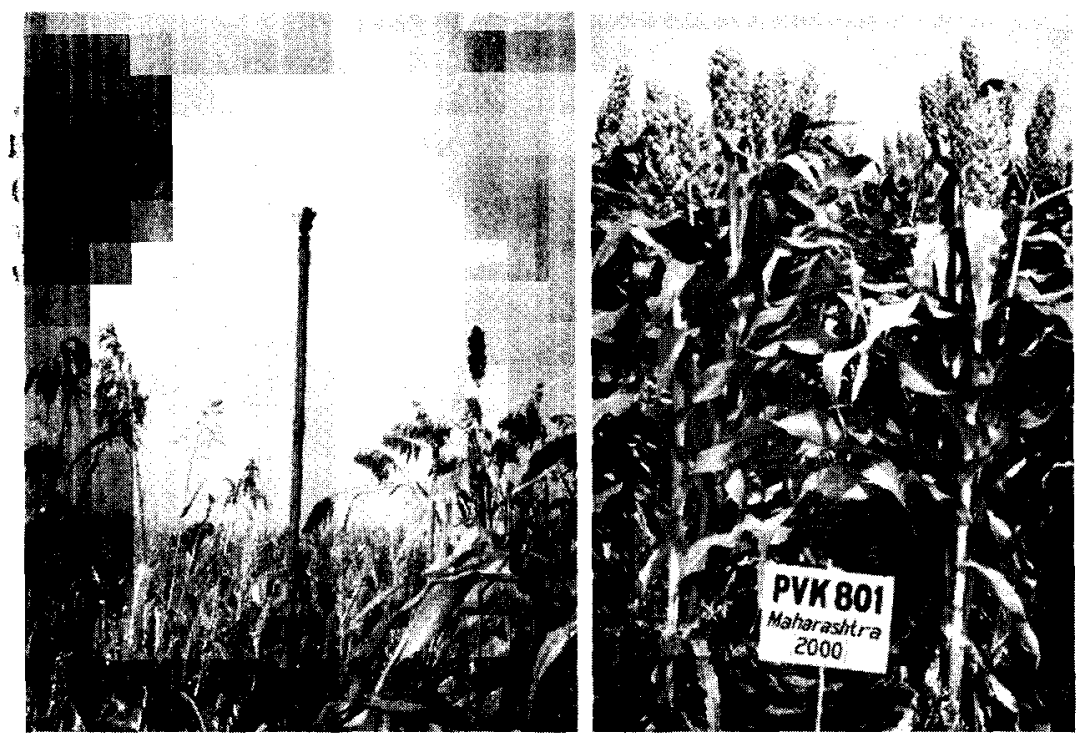

Figure 11.3 (See color insert following page 114.) (Left) Screening of grain mold in sorghum by sprinkler irrigation method. (Right) An ICRISAT public sector-bred grain mold-resistant sorghum variety.

techniques, (3) well-defined sources of resistance are available, and (4) the expected economic output will occur within a given time.

Breeding for disease resistance in sorghum began about three decades ago (Rosenow 1992; Mukuru 1992). Usually an agronomically good, high-yielding cultivar is crossed to other parents with disease resistance, good grain quality, local adaptation, etc. Disease control through host genetic manipulation is difficult and has been slower for charcoal rot and grain mold, in which gene effects are small, compared to downy mildew, anthracnose, and leaf blight, in which gene effects are large (Thakur et al. 1997).

Current breeding methods at ICRISAT include both pedigree and population improvement for grain mold-resistance breeding (Figure 11.3). Pedigree selection using artificial screening for grain mold-resistance has resulted in high-yielding lines and hybrid parents with white grain types. A random mating population with white grains and guinea-type panicle and glume traits is being improved at ICRISAT. Male sterile lines with white, red, and brown grain colors and with resistance to grain mold have been developed. The possible roles of antifungal proteins that inhibit the growth of grain mold fungi are being investigated at ICRISAT and Texas A\&M University. Several male sterile lines resistant to anthracnose (Colletotrichum graminicola) have been developed at ICRISAT.

\subsubsection{Striga Resistance}

Witchweed (Striga spp.) is endemic to subtropical regions of the world and comprises about 36 species, of which around 31 occur in Africa (Raynal-Roques 1987). Five species of Striga attack cultivated cereals: Striga hermonthica (Del.) Benth, Striga aspera (Willd) Benth, Striga forbesii Benth, Striga asiatica (L) Kuntze, and Striga densiflora Benth (Doggett 1984). Only three species are of widespread economic importance in Africa: Striga asiatica and S. hermonthica, which attack cereals, and Striga gesnerioides, which parasitize legumes, principally cowpea (Vigna unguiculata) (Doggett 1988).

$S$. asiatica occurs mainly in southern and central Africa, while $S$. hermonthica predominates in the semiarid zones of tropical eastern, central, and western Africa, where it attacks food crops such as sorghum, pearl millet (Pennisetum glaucum), maize (Zea mays), upland rice (Oryza sativa), sugarcane (Saccharum officinarum), and several wild grasses (Tarr 1962; Doggett 1988). S. her- 
monthica and $S$. asiatica are obligate parasitic weeds of sorghum with significant economic importance. The yield losses from damage are often significant, with estimates varying from 10 to $70 \%$, depending on crop cultivator and degree of infestation (Doggett 1988).

Characterization of germplasm, development of simple and efficient screening techniques, and a well-planned selection strategy for yield and other traits of importance in subsistence agriculture are essentials for breeding Striga resistance. Given the widespread Striga problem and the opportunities for natural and deliberate selection in environments where the host and parasite have coevolved, there has been suprisingly low genetic variability for Striga resistance in sorghum germplasm (Ejeta et al. 1997).

\subsection{Striga Screening Techniques}

Evaluation of host plant resistance to Striga in Striga-infested plots has been unsuccessful due to the inconsistent nature of Striga infestation both within the same field and among different fields across years, and due to complex interactions among the host, parasite, and environmental factors that affect the establishment of the parasite (Ejeta and Bulter 1993a; Volger et al. 1995).

Rapid laboratory screening procedures that predict field resistance to Striga on a per plant basis have been developed, with the double-plot technique and agar gel assay useful in screening large numbers of breeding progenies (Parker et al. 1977; Hess et al. 1992). The assay correlated well with the reported field resistance of the cultivars tested (Hess et al. 1992; Volger et al. 1995). This assay proved that Striga resistance in SRN 39, a superior source of field resistance against Striga, was primarily due to low production of germination stimulants and led to the release of this line for commercial cultivation in Striga-endemic areas of Sudan (Hess and Ejeta 1992; Volger 1992). This line is used extensively as a source of Striga resistance in a sorghum improvement program at Purdue University and at ICRISAT (ICRISAT 1982; Volger et al. 1995).

\subsection{Striga Breeding Strategies}

Both interspecific variability among Striga spp. and intraspecific variation for aggressiveness must be taken into account when breeding for Striga resistance (Ramaiah 1987; Ejeta et al. 1992). In order to obtain stable and polygenic resistance, breeding materials should be evaluated at multiple locations with different Striga populations or host-specific races (Ramaiah 1987). In addition to multilocational testing, breeding strategies should endeavor to:

1. Characterize crop germplasm, search for sources of resistance and tolerance in elite material, or improve currently available sources of resistance for agronomic performance

2. Include wild relatives with superior resistance in the breeding program

3. Pyramid resistance genes to obtain more durable and stable polygenic resistance

4. Transfer resistance genes into productive, well-adapted genotypes

5. Combine lines with different resistance mechanisms to form hybrids or synthetics to increase durablility of the resistance (Ramaiah 1987; Ejeta et al. 1992; Ejeta and Bulter 1993b; Burner et al. 1995; Haussmann et al. 2000a; Kling et al. 2000)

Other important considerations include careful definition of the target environment, farmer participation in identification of adapted parents for use in a backcross program, and determination of the most important region-specific selection traits, such as grain color and quality, plant height, maturity, photoperiod sensitivity, and disease resistance (Rattunde et al. 2000). The optimal genetic structure of the culitivar (i.e., degree of heterozygosity and heterogeneity) will also depend on the target environment, with the potential merit of heterozygous sorghum cultivars having significantly greater yield (18\%) under Striga infestation than their parental lines (Haussmann et al. 2000a,b; Kling et al. 2000; Hess and Ejeta 1992). 
Although several Striga-resistant lines were identified from the germplasm based on extensive laboratory and field screening at ICRISAT, many of them could not be used in the breeding programs due to their undesirable agronomic base. However, some germplasm lines were used in Striga resistance breeding, and several Striga-resistant male sterile lines have been developed. The Strigaresistant variety SAR 1 developed at ICRISAT was released for cultivation in Striga-endemic areas. Several Striga-resistant varieties have been identified in eastern, southern, and western Africa, Nigeria, and Sudan (Bebawi 1981; Obilana 1983; Ramaiah 1987; Riches et al. 1987; Doggett 1988; Obilana et al. 1991, Mbwaga and Obilana 1994; Hess et al. 1996). However, less than 50\% of these varieties remain in use today, as some of them have been used as parents in developing the new and improved resistant lines.

In general, conventional approaches for breeding durable Striga resistance have not been successful due to (1) species-specific resistance against Striga; (2) intraspecific or physiological variants of Striga; (3) paucity of resistant genes in crop germplasm (Ejeta et al. 1991, 1997); (4) difficulty, expense, and occasional unreliability of testing for Striga resistance; (5) quarantine of the parasite; and (6) recessive character of some resistance genes (Haussmann et al. 2000a). A mix of conventional and marker technology approaches may have to be employed in the future in breaking down Striga resistance into simpler components that can be exploited for developing crop genotypes with durable resistance (Ejeta et al. 1997; Haussmann et al. 2000a).

\subsubsection{Drought Tolerance}

Drought stress is a major constraint to sorghum production worldwide. Although sorghum possesses excellent drought resistance compared to most other crops, improving its drought resistance would increase and stabilize grain and food production in low-rainfall, harsh environmental regions of the world (Rosenow et al. 1997). Drought resistance is the phenotypic expression of a number of morphological characteristics and physiological mechanisms, including drought escape, dehydration avoidance, and dehydration tolerance (Ludlow 1993). Therefore, drought resistance in sorghum is a complex trait affected by several interacting plant and environmental factors.

The response of sorghum to soil moisture stress is largely determined by the stage of growth at which moisture stress occurs, with two distinct responses to drought stress identified. The preflowering (mid-season) drought response is expressed when plants are stressed during panicle differentiation prior to flowering, while the postflowering drought response is expressed when moisture stress occurs during the grain filling stage (Rosenow and Clark 1995). Two further responses were described by ICRISAT: where emergence under crust and high temperature prevailed in drought-prone environments and wherein the lines with long mesocotyl emerge earlier than others; and early-stage (120-day-old seedlings) drought recovery where distinct differences among the genotypes are observed (Reddy 1985).

Research at ICRISAT screened and identified progenies with high levels of preflowering stress recovery, which were further selected for grain yield alternatively under mid-season drought and yield potential environments in India. When tested in drought-prone environments in Africa, these lines had greater stability and grain and biomass yield than other varieties. Similarly, promising lines with resistance to seedling emergence under crust and high temperature were also identified (ICRISAT 1982, 1986, 1987).

Symptoms of postflowering drought stress susceptibility include premature plant (leaf and stem) death or plant senescence, stalk collapse and lodging, charcoal rot (Macrophomina phaseolina), and a significant reduction in seed size, particularly at the base of the panicle. Tolerance is indicated when plants remain green and fill grain normally. Such green stalks also have good resistance to stalk lodging and charcoal rot. Such cultivars are referred to as having the stay-green trait.

Stay-green is as an important postflowering drought resistance trait. Genotypes possessing staygreen are able to maintain a greater green leaf area under postflowering drought than their senescent counterparts (Rosenow et al. 1997). Recent studies have shown that leaves stay green not only 
because of small sink demand but also due to higher leaf nitrogen status and transpiration efficiency, resulting in maintenance of photosynthetic capacity and, ultimately, higher grain yield and lodging resistance (Borrell and Douglas 1997; Borrell et al. 1999, 2000b; Borrell and Hammer 2000). Greater green leaf area duration during grain fill appears to be a product of different combinations of three distinct factors: green leaf area at flowering, time of onset of senescence, and subsequent rate of senescence. All are independently inherited and easily combined in breeding programs (Van Oosterrom et al. 1996; Borrell et al. 2000a). Stay-green hybrids produce significantly greater total biomass after anthesis, retain greater stem carbohydrate reserves, maintain greater grain growth rates, and have significantly greater yields under terminal drought stress than related but senescent hybrids (Henzell et al. 1997; Borrell et al. 1999, 2000b). Several physiological traits, such as heat tolerance, desiccation tolerance, osmotic adjustments, rooting depth, and epicular wax, are known to improve drought resistance (Downes 1972; Sullivan 1972; Sullivan and Ross 1979; Turner 1979; Jordan and Monk 1980; Kramer 1980; Jordan and Sullivan 1982; Peacock and Sivakumar 1987; Levitt 1992; Krieg 1993; Ludlow 1993; Van Oosterrom et al. 1996; Henzell et al. 1997). Although screening techniques based on these traits for drought resistance have been reported, little if any progress using specific physiological traits has been documented, partly because interaction of various physiological mechanisms involved in drought tolerance is still poorly understood (Chrisiansen and Lewis 1982; Garrity et al. 1982; Seetharama et al. 1982; Blum 1983, 1987; Jordan et al. 1983; Ejeta 1987; Bonhert et al. 1995).

The stay-green trait has been successfully used in Australia to develop postflowering drought stress resistance and lodging resistance in parental lines and commercial hybrids. Conventional breeding for stay-green is primarily based on two sources, B 35 and KS 19, of Ethiopian and Nigerian origin, respectively (Henzell et al. 1984, 1992a,b; Henzell and Hare 1996; Rosenow et al. 1997; Mahalakshmi and Bidinger 2002). KS 19 has been commercially used primarily in the breeding program of the Queensland Department of Primary Industries and Fisheries (QDPIF), while B 35 is widely used in both public and private sector breeding programs in the U.S. (Henzell and Hare 1996). B 35 has provided the major and best sources of stay-green used in the QDPIF program, and produced the key line QL 41, with high levels of stay-green expression. Crosses between QL 41 and sorghum midge-resistant lines formed the basis of the female stay-green and midge-resistant gene pool in the QDPIF programs, although less progress has been made in developing such germplasm in the male population (Rosenow et al. 1983; Henzell et al. 1997).

Germplasm and breeding lines tolerant to specific drought environments have been identified at ICRISAT; 36 lines with a stay-green score ranging from 1 to 2 on a scale of 1 to 5 (where $1=$ more green and $5=$ least green) and a plant agronomic score ranging from 1 to 3 on a scale of 1 to 5 (where 1 = very good and $5=$ poor) were selected. For details see ICRISAT's webpage: http:/www.ICRISAT.ORG/Text/research/grep/homepage/sorghum/breeding/main.htm.

Most commercial sorghum hybrids in the U.S. possess good tolerance to preflowering drought stress; however, only a few have good postflowering resistance (Nguyen et al. 1997). In spite of the availability of simply inherited stay-green trait associated with terminal drought tolerance, progress in enhancing postflowering drought resistance is slow because the expression of this trait is strongly influenced by environmental factors and because of the limited number of stay-green sources currently used in sorghum breeding programs (Henzell and Hare 1996; Henzell et al. 1997).

Stay-green is expressed best in environments in which the crop is dependent on stored soil moisture but where this is sufficient to meet only a part of the transpiration demand. Sufficient expression of the trait for selection is thus dependent upon the occurrence of a prolonged period of drought stress of sufficient severity during the grain filling period to accelerate normal leaf senescence but not of sufficient magnitude to cause premature death of the plants (Henzell and Hare 1996). Because of this precise requirement for the trait expression, field environments do not offer ideal conditions for selection, and therefore, identification of quantitative trait loci (QTL) conferring stay-green trait and the molecular markers tightly linked to these QTL will provide 
powerful tools to enhance drought resistance (Henzell and Hare 1996; Crasta et al. 1999; Xu et al. 2000).

\subsubsection{Soil Chemical Toxicity Tolerance}

The demand for cereal grains in tropical environments characterized by soils that impose mineral stresses has mandated additional breeding research to adapt sorghum to these environments (Gourley et al. 1997a). Soil acidity (and associated $\mathrm{Al}^{3+}$ toxicity) and salinity are probably the most important constraints to sorghum productivity in tropical environments, with an estimated 72.4 billion ha $(18 \%)$ of the world's soils classed as acidic and 0.9 billion ha classed as saline and sodic (Vose 1987; Gourley et al. 1997a). These problematic soils cause more acute crop production constraints for resource-poor tropical farmers in developing countries than for temperate zone farmers in developed countries. However, improvement in nutrient use efficiency and tolerance to toxicities would benefit all farmers.

\subsection{Inheritance and Breeding for Soil Acidity Tolerance}

Tolerance to soil acidity and $\mathrm{Al}^{3+}$ toxicity in sorghum is controlled by a few dominant genes under additive and nonadditive action (Flores et al. 1991; Adamou et al. 1992; Zake et al. 1992; Maciel et al. 1994a; Gourley et al. 1997a). Soil acidity stress factors vary with location, soil depth, rainfall, temperature, effective cation exchange capacity (ECEC), natural content of essential elements, level of toxic ions, p-fixation capacity, and amount and quality of organic matter (OM) (Gourley et al. 1997a). These factors combined with a poor correlation of results obtained in nutrient culture for acidity tolerance in field or greenhouse studies are the causes of complexity of breeding for tolerance to soil acidity (Horst 1985; Marschner 1991). Nevertheless, much progress has been made since the EMBRAPA sorghum for tolerance to acid soils and International Sorghum and Millets (INTSORMIL) sorghum acid soil breeding project were initiated in Columbia in 1981 (Schaffert et al. 1975).

Many sorghum lines have been identified with good levels and substantial genetic variability in $\mathrm{Al}^{3+}$ toxicity tolerance (de Andrade Lima et al. 1992; Maciel et al. 1992, 1994b; Gourley et al. 1997a). More than 6000 sorghum genotypes from the world collection were screened at Quilichao, Colombia, with around $8 \%$ found to tolerate $65 \% \mathrm{Al}^{3+}$ saturation, with a few of these genotypes able to produce greater than $2 \mathrm{t} \mathrm{ha}^{-1}$ of grain (Gourley 1988). Many of these highly tolerant genotypes from the world collection originated in acid soil areas in Nigeria, Uganda, or Kenya and were classified as caudatum or caudatum hybrid races. The open-panicled guinea race and the hybrid guinea-bicolor lines had a higher overall percentage of acid-tolerant sorghum entries than those of other races and hybrids evaluated (Gourley 1988).

The INTSORMIL and EMBRAPA projects used a pedigree breeding method to identify Altolerant plants and screened the $\mathrm{F}_{2}$ plants at 65 and $45 \% \mathrm{Al}$ saturation, respectively. The resulting tolerant lines had yields between 2.6 and $4.6 \mathrm{t} \mathrm{ha}^{-1}$, with the INTSORMIL lines shorter and earlier than the EMBRAPA lines (Gourley et al. 1997a). About 170 grain sorghum inbreds with tolerance to $\mathrm{Al}$ saturation levels of tropical acid soils developed by pedigree breeding have been released as germplasm by the Mississippi Agricultural and Forestry Experiment Station (MAFES) (Gourley et al. 1997b).

ICRISAT and Centro International de Agriculture Tropical (CIAT) screened large numbers of grain sorghum lines (male sterile, restorer, and forage lines) over four consecutive seasons under varied $\mathrm{Al}^{3+}$ concentrations and identified high-yielding male sterile lines (MS), restorer lines, and forage sorghums tolerant to $\mathrm{Al}^{3+}$ that have been distributed to various agencies in the region (ICRISAT, NARS, CIAT 1997). Evaluation of these high-yielding breeding materials in multiple locations resulted in the identification of many $\mathrm{MS}, \mathrm{R}, \mathrm{B}$, and forage lines with wide adaptability (regression coefficient between 0 and 1) (Reddy et al. 1998; Reddy and Rangel 2000). 
Four of the nearly 200 sorghum hybrids evaluated at Matazul $\left(60 \% \mathrm{Al}^{3+}\right.$ and $4.6 \%$ organic matter) were found to have outstanding tolerance to soil acidity, and they were also less susceptible to leaf diseases, were greener at the time of maturity, and were also taller than the control Real 60 (ICRISAT 2000). Hybrids therefore hold promise for improving the sustainability of acid savannas (Reddy et al. 2004a,b).

\subsection{Inheritance and Breeding for Soil Salinity Tolerance}

Studies on genetic basis of variability for salinity tolerance in sorghum are rather limited (Azhar and McNeilly 1989; Haggag et al. 1993; de la Rosa Ibarra and Maiti 1994; Fernandes et al. 1994; Igartua et al. 1994; Jiqing Peng et al. 1994; Maiti et al. 1994; Richter et al. 1995). The genetic control of salinity tolerance appears to be complex, with both additive and dominant gene effects important in controlling the expression of salt tolerance; however, the effect of dominant genes appears to be most important (Igartua et al. 1994).

Early screening for salt stress-tolerant sweet sorghum genotypes can be done in vivo by (1) growing the seedlings on sand in polystyrene containers and (2) growing the seedlings in spectrophotometer cuvettes (Montemurro et al. 1994). Genotypic response to salt stress is similar in both methods, and classification of sweet sorghum genotypes for salt tolerance was effectively demonstrated. A third method was suggested by Hassanein and Azab (1990) where seeds of sorghum genotypes are grown in water (control) and $\mathrm{NaCl}$ solution $(\mathrm{ECE}=12,16$, or $20 \mathrm{mhos} / \mathrm{cm})$.

\subsection{Biochemical Basis of Resistance to Salinity}

The concentration of biochemical components such as proline and hydrocyanic acid (HCN) increases with an increase in salinity levels in resistant genotypes but not in the susceptible genotypes of sorghum at the seedling stage (Richards and Dennett 1980; de al Rosa Ibarra and Maiti 1994). The detailed study of resistance mechanism of these lines would aid in incorporation of resistance in elite agronomic background.

Attempts to breed sorghum for salinity tolerance is rather limited. The major problem breeding sorghum for abiotic stresses such as salinity is the choice of optimal selection environments due to the high levels of both spatial and temporal variation in salinity-affected fields (Richards and Dennett 1980; Richards et al. 1987; Igartua 1995). Spatial variation occurs horizontally and vertically on very small scales, and therefore, most salinity-affected lands are actually comprised of many microenvironments, ranging from low to high salinity in the same field (Igartua 1995).

Testing genotypes across a broad range of salinity levels shows that genotype $\times$ salinity level interactions are commonly large and significant in sorghum, forcing the plant breeder to decide whether to work over the whole target environment (breeding for wide adaptation) or subdivide it into more homogeneous subenvironments (breeding for specific adaptation) (Azhar and McNeilly 1987; Igartua 1995). This decision depends mainly on the relative sizes of the genotype $\times$ year and genotype $\times$ location interaction (Austin 1993).

The target environments, both for breeding for saline soils and for wide adaptation, are actually a population of many possible environments, for which there exists a significant component of genotype $\times$ environement interaction (Igartua 1995). Three environment selection strategies have been proposed: (1) make selection in a stressful environment, (2) select under optimum growing conditions, and (3) use a combination of both the approaches; i.e., select materials that perform well under both stress and nonstress conditions (Calhoun et al. 1994). Option 3 appears to be the best, as separate selection for distinct environments is not possible, and greater accuracy of selections is achieved over more environments used (Igartua 1995). Selection of breeding populations for salinity tolerance over three salinity levels - low, high, and average of the two extreme levels - instead of the whole range of salinity levels, has demonstrated the usefulness of option 3 to 
select for improved yield in grain sorghum under saline soil conditions (Maas and Hoffman 1977; Igartua 1995).

Salinity causes more serious damage to sorghum at the seedling emergence stage than an an other stage (Jiqing Peng et al. 1994). Therefore, enhancing the salinity tolerance of grain sorghum at the germination emergence stage should be one of the breeding objectives sought for areas affected by soil salinity (Hassanein and Azab 1990). The effectiveness of divergent selection for tolerance to salinity at the germination emergence stage in grain sorghum has been demonstrated, where subsets of the progenies showing best and least tolerance to salinity were selected and recombined to constitute the next cycle. Evaluation of the original and four subpopulations under saline conditions evaluated in the laboratory and the field for germination emergence ability revealed the effectiveness of selection in separating the subpopulations (Igartua and Gracia 1998).

\subsubsection{Increased Nutritional Quality}

While mostly rural poor in semiarid developing countries consume sorghum as human food, it is used as animal feed in developed countries and may in the future be utilized more for feed in developing countries (Hamaker and Axtell 1997). The starch content of whole sorghum is about $70 \%$, and its protein content is about $11 \%$ (flour weight basis), which is higher than in maize (Klopfenstein and Hoseney 1995).

The nutritional quality of sorghum is poor compared to other cereals, mainly due to the predominance of storage proteins, i.e., prolamins (Kafirins), which are known to be extremely low in the essential amino acid lysine, rich in leucine, and have low protein digestibility (which is lowered when the grain is cooked) (Deosthale et al. 1972; Maclean et al. 1983; Rao et al. 1984a; Magnavaca et al. 1993). People who depend on sorghum in their diet often develop pellagra mainly on account of a high leucine and isoleucine ratio (Gopalan and Srikantia 1960).

Sorghum is usually rich in glutamic acid, leucine, alanine, proline, and aspartic acid, with the level of amino acid highly positively correlated with protein content (Waggle and Deyoe 1966). Similar protein content of immature and mature grain, coupled with higher content of lysine, aspartic acids, and glycine and much lower glutamic acid, proline, and leucine, makes immature grain more nutritionally balanced than mature grain in terms of amino acid composition (Deyoe et al. 1970). Albumin and globulin, glutein, and prolamins are the best, intermediate, and poorest proteins, respectively, in terms of nutrition (Virupaksha and Sastry 1969; Wall and Blessin 1970).

Sorghum proteins have reduced digestibility due to (1) protein cross-linking, which lowers protein solubility, (2) a stronger association of proteins with undigested fiber components, and (3) the presence of a high proportion of peripheral endosperm with high levels of protein (Rooney and Plugfelder 1986). Although nitrogen fertilization can increase protein, lysine, and tryptophan yields per unit area, such an increase is associated with decreased concentrations of these amino acids in the grain (Deosthale et al. 1972).

Total lysine content and total biological value of sorghum protein can be compensated by the addition of synthetic amino acid, legumes, leafy vegetables and other cereal grains, and fermentation of sorghum grains (Pushpamma et al. 1970; Au 1979). Similarly, protein digestibility can be improved by decortication and extrusion of grain and by cooking in the presence of a reducing agent (Maclean et al. 1983; Hamker et al. 1987). However, genetic enhancement is the most sustainable and economical option to increase lysine content and improve protein digestibility.

\subsection{Genetic Variability for Protein Content and Amino Acid Composition}

Considerable variability has been reported for protein content as well as essential amino acid levels such as lysine, methionine, tryptophan, histidine, arginine, aspartic acid, threonine, serine, glutamic acid, proline, glycine, alanine, cystine, valine, methionine, isoleucine, tyrosine, and phe- 
nylalanine (Virupaksha and Sastry 1968, 1969; Deosthale et al. 1970; Reich and Atkins 1971; Mali and Gupta 1974; Nanda and Rao 1975a, 1975b).

\subsection{Genetics of Protein Content and Its Digestibility}

While protein content of sorghum grain is governed by additive gene action, essential amino acids such as lysine and methonine are controlled by both additive and nonadditive gene action. Another essential amino acid, tryptophan, appears to be governed by nonadditive gene action (Nanda and Rao 1975a, 1975b; Rana and Murty 1975; Singhania et al. 1979; Nayeem and Bapat 1984; Chinna and Phul 1986; Mallick et al. 1988). While the high lysine natural mutant gene ( $h l$ ) is monogenic recessive (Singh and Axtell 1973), lysine content is inherited as a single gene with partial dominance in p-721 Q, a chemically induced high lysine mutant of sorghum (Mohan 1975; Axtell et al. 1979). Similarly, protein digestibility in a sorghum line, p-851171 derived from p-721 $\mathrm{Q}$, is inherited as a simple Mendelian trait (Oria et al. 2000; Axtell 2001).

\subsection{High Protein Digestibility and High Lysine Content}

The identification of naturally high lysine Ethiopian sorghum mutants from the world sorghum collection, a chemically induced high-lysine mutant, and the recent identification of a sorghum line with high protein digestibility levels surpassing that of maize facilitated the prospects for combining high nutritional quality and grain yield (Singh and Axtell 1973; Mohan 1975; Oria et al. 2000).

The two high-lysine Ethiopian lines, IS 11758 and IS 11167, have exceptionally high lysine contents, are photoperiod sensitive, tall, and late, and have shrivelled or dented seeds. Their acceptance is limited due to many problems associated with their opaque kernel, reduced grain yield, slow drying in the field, increased susceptibility to molds and insects, and the tendency of the seed to crack when mechanically harvested (Rao et al. 1984a; Ejeta and Axtell 1990). Similarly, the chemically induced high-lysine strain p-721 Q has soft kernel and floury endosperm with reduced yielding ability (Axtell 2001; Rao et al. 1984b; Asante 1995).

Earlier attempts to select agronomically desirable recombinants that are dwarf to medium plant height, are early maturing, and are relatively photoperiod insensitive with superior protein quality from various cross-combinations of the very tall, late, photoperiod-sensitive Ethiopian high-lysine parents were not fruitful (Rao et al. 1983b). Although it was possible to select plump, corneous grain types with the high-lysine trait, as breeding continued and generations advanced, there was a reduction in the frequency of plants with high levels of lysine. Selection during 1994 from a high-lysine population developed at Purdue University in the U.S. had 0.30 to $0.49 \%$ lysine (flour basis), compared to normal sorghum cultivars that contain about $0.24 \%$ lysine, with grain yield in this group ranging from 3 to $4 \mathrm{t} \mathrm{ha}^{-1}$ (Hamaker and Axtell 1997). Establishment of a negative correlation between protein and lysine content in several segregating generations of Ethiopian highlysine $\times$ agronomically superior varieties forced the breeders to improve lysine at moderate protein levels (Rao et al. 1983a, 1984b).

Ejeta and Axtell (1990) were able to select modified endosperm of p-721 opaque (high-lysine mutant) with vitreous kernels similar to normal types. But vitreous phenotypes have been detected in an advanced generation $\left(\mathrm{F}_{6}\right)$ of breeding. However, crosses between p-721 Q (high protein digestibility) and other elite lines resulted in improved yields (Axtell et al. 1979). The recent identification of a sorghum line, p-851171 (a derivative of p-721 Q), with protein digestibility levels surpassing that of maize raises the hopes of improving protein digestibility in sorghum (Oria et al. 2000). However, to date, no studies have examined the association between protein digestibility and lysine concentration in crosses involving p-851171 (Axtell 2001).

Recent development of a rapid protein digestibility assay for identifying highly digestible sorghum lines will help in screening a large number of breeding lines for protein digestibility (Aboubacar et al. 2002). Sorghum germplasm with high protein digestibility as high or higher than 
maize or other staple cereals have been identified through Purdue/INTSORMIL research. In addition, lines having vitreous kernels with good food grain and processing properties have been identified and are available for breeding programs at Purdue University (Axtell 2001).

\subsection{Sorghum Whole-Grain Digestibility and Its Improvement}

Whole-grain digestibility of sorghum is sometimes a problem; however, local processing techniques convert sorghums into digestible foods. Development of highly digestible sorghum is desirable, but in many environments, the highly digestible sorghums are predigested by molds and insects in the field and have quite low yields. Therefore, highly digestible types may be limited to production in extremely dry environments, where the grain is not subjected to humidity after maturity. It is difficult to improve digestibility without enhancing the susceptibility of the grain to deterioration; thus, efforts to enhance digestibility of sorghum must be done with care (Rooney et al. 2003).

\subsection{Tannins and Other Polyphenols and Their Genetic Manipulation}

Contrary to the belief of many scientists and nutritionists that all sorghums contain tannins, sorghums without a pigmented testa do not contain tannins (Bulter 1990a). The tannin (brown) sorghums have a very definite pigmented testa (caused by combination of dominant $B_{1}-B_{2}-S$ genes) with levels of condensed tannins and may offer resistance to birds and grain mold (Tipton et al. 1970; McMillian et al. 1972; Bulter 1990b; Rooney et al. 2003). The rate of preharvest germination is significantly lower for most high-tannin sorghums (Asante 1995; Harris and Burns 1970; Chavan et al. 1980).

Huge losses in yield due to bird damage in nonresistant sorghum hybrids have been reported in the U.S. (Anonymous 1967; Harris 1969; Tipton et al. 1970). Hence, the beneficial effects of tannins in conferring bird resistance continue to be important in bird-affected areas of the world, particularly Africa (Bulter 1990b). However, experience in Africa has shown that birds will eat high-tannin sorghums when alternative food sources (such as white-grained sorghum) are not available. Nutritionally, tannins interact with and precipitate protein during processing. The level of tannins in high-tannin sorghums is enough to cause significant antinutritional effects, especially if the diet is inadequate in protein (Bulter 1990b). Adding extra protein to the ration overcomes the effects of the tannins. The tannin sorghums decrease feed efficiency by about $10 \%$ when fed to livestock. The tannin sorghums have high antioxidant activities and may be a very important source of nutraceuticles. Thus, we might someday use the sorghums with a pigmented testa and dominant spreader gene as potent, more efficient sources of antioxidants than fruits or berries (Rooney et al. 2003).

\subsubsection{Increased Micronutrient Density}

Micronutrient malnutrition, primarily the result of diets poor in bioavailable vitamins and minerals, causes blindness and anemia (even death) in more than half of the world's population, especially women and preschool children. Two micronutrients, iron $(\mathrm{Fe})$ and zinc $(\mathrm{Zn})$ and provitamin A (carotene) are recognized by the World Health Organization (WHO) of the United Nations as limiting. Deficiency for Fe, $\mathrm{Zn}$, and -carotene is highest in South and Southeast Asia and sub-Saharan Africa. These are also the regions where sorghum is cultivated and consumed as food by a large number of people. Therefore, biofortification of sorghum provides the needed micronutrients and -carotene by taking advantage of the consistent daily consumption of large amounts of sorghum food by people.

By breeding sorghum for high levels of micronutrients and -carotene in grain, the plant breeding strategy seeks to develop sorghum with inherent fortification. Plant breeding holds great promise for making a significant, low-cost, and sustainable contribution to reducing micronutrient and -carotene deficiencies without resorting to programs that depend on behavioral change in people who consume sorghum as a staple food. However, this approach will be successful only if farmers are willing to adopt such varieties, if the edible parts of these varieties are palatable 
and acceptable to consumers, and if the incorporated micronutrients can be absorbed by the human body (Bouis et al. 2000). The fundamental assumption in proposing a plant breeding option to overcome micronutrient malnutrition is that nutrient density traits must be delivered in cultivars of the highest yield. In order to have maximum impact, top-yielding lines are needed to convince local farmers to grow them when the target consumer is in no position to pay a higher price for quality. To do this, a major increase in breeding costs will be necessary in order to maintain progress in yield concurrently (Graham et al. 1999).

Studies on $\mathrm{Fe}$ and $\mathrm{Zn}$ bioavailability in rats fed with genetically enriched beans and rice have indicated that enriching these staples with $\mathrm{Fe}$ and $\mathrm{Zn}$ provides significantly more bioavaiable $\mathrm{Fe}$ and $\mathrm{Zn}$ (Platt 1962). If this is true (optimistically presumed true) with genetically enriched sorghum with $\mathrm{Fe}$ and $\mathrm{Zn}$, then consumption of such enriched sorghum would amount to a $50 \%$ increase in the dietary intake of $\mathrm{Fe}$ and $\mathrm{Zn}$ among several million families consuming sorghum as a staple food, and hence should support breeding sorghum with improved $\mathrm{Fe}$ and $\mathrm{Zn}$ micronutrient contents.

Sorghum is richer in $\mathrm{Zn}$ and $\mathrm{Fe}$ than most other cereals, such as pearl millet, maize, rice, and wheat (Platt 1962). Considering the prospects of large genetic variability and presumably simpler genetic inheritance for $\mathrm{Zn}$ and $\mathrm{Fe}$, as evidenced from other cereals like rice, wheat, and maize, these mineral nutrients levels can be further improved through concerted breeding efforts (Banziger and Long 2000; Gregorio et al. 2000; Monasterio and Graham 2000). A fairly good variability coupled with additive genetic inheritance and moderate heritability of -carotene levels brightens the prospects of improving this trait in sorghum (Nanda and Rao 1974, 1975a,b).

\subsection{NEW TOOLS FOR SORGHUM IMPROVEMENT}

\subsubsection{Farmers' Participatory Approach}

The development of cultivars with farmers' preferred traits through farmers' participation in crop breeding provides an option in the development of cultivars adapted to a wide range of environments (Gowda et al. 2000). Farmer participatory approaches to breeding of improved crop cultivars are categorized into participatory varietal selection (PVS) and participatory plant breeding (PPB). Both PVS and PPB are relatively new approaches for crop improvement (Maurya et al. 1988; Witcombe et al. 1996). PVS involves farmers selecting suitable varieties from finished or near-finished breeding material/lines arising from on-station crop improvement programs through a process of evaluation in their fields and under their own management. PPB involves farmers selecting from the breeder-developed segregating material and is a logical extension of PVS. A detailed methodology of these two approaches and their comparison to conventional breeding methods can be found in Witcombe et al. (1996).

A higher adoption rate of varieties developed using farmer participation is expected as the varieties are better suited for resource-poor farmers, and they facilitate a liberal release system through horizontal spread from farmer to farmer (Rana et al. 1998). While the long-term aim of PVS is to increase biodiversity, where indigenous variability is high, it can also reduce biodiversity (Witcombe et al. 1996). PPB has a greater effect in increasing biodiversity, although its impact may be limited to smaller areas, with PPB a dynamic form of in situ genetic conservation (Witcombe et al. 1996). PPB has been used to a rather limited extent compared to PVS. In Ethiopia, yield potential of landraces of Sorghum has been enhanced by mass selection by farmers in collaboration with the scientists from the Plant Genetic Resources Center (Worede and Mekbib 1993).

The farmer participatory approach was used to make crosses between rabi landraces and improved varieties for the postrainy season in India. These crosses were made to compare the efficiency of conventional breeding and PPB (Reddy et al. 2004a), and participatory varietal selection facilitated the release of the variety SPV 1359 for postrainy season cultivation in Maharashtra and Karnataka States in India during the year 1999-2000. 
Participatory sorghum improvement has been used in Africa focusing on two key objectives: (1) modification of the priorities and objectives of sorghum improvement research for Mali to better meet farmers' needs and preferences and (2) farmer assessment of specific new varieties of sorghum in a wide range of production zones (Rattunde 2002). With an objective of developing diversified sorghum populations and lines that incorporate farmer-preferred plant and grain traits, the program succeeded in identifying several genotypes that possessed suitable traits for plant height, maturity duration, resistance to drought, grain (size and color), yield ability, and actual grain yield, with four varieties enjoying wide farmer preference (Chintu 2000).

Improved sorghum cultivars developed by ICRISAT in collaboration with the Institute for Agricultural Research (IAR) were evaluated using farmer participation, with the cultivars outyielding local varieties. The farmers accepted these improved cultivars because of their terminal drought tolerance, easy threshability, bold grain, medium height, and succulent and palatable fodder (Tabo et al. 1999).

\subsubsection{Biotechnology}

Traditional plant breeding has made significant contributions to sorghum improvement; however, they have been slow in targeting complex traits like grain yield, grain quality, drought tolerance, cold tolerance, and resistances to many pests and diseases. For efficient genetic management of such traits, biotechnology offers new and potentially powerful tools to plant breeders. Of the wide range of biotechnological tools, DNA marker technology and genetic transformation have wide application in crop improvement programs across the globe and are discussed in this section.

\subsubsection{DNA Marker Technology}

DNA markers have the potential to enhance the operation of plant breeding programs through a number of ways, including fingerprinting of elite genetic stocks, assessment of genetic diversity, addressing genome evolution, phylogeny relevant to germplasm management, increasing the efficiency of selection for difficult traits through their tight linkages with DNA markers, and making environment-neutral selection to map-based cloning (Ejeta et al. 2000; Subudhi and Nguyen 2000). The long-term utility of marker-assisted selection in sorghum improvement is likely to be jointly determined by the identification and mapping of phenotypes with a direct impact on productivity and quality, but which are difficult to study and manipulate by classical means (Paterson 1994). The integration of marker-assisted selection (MAS) into conventional plant breeding promises a more rapid pyramiding of desirable genes into improved cultivars to provide durable resistance (Haussmann et al. 2000b).

Traits that are suitable for molecular breeding include tolerance to drought and heat and resistances to Striga, grain mold, downy mildew, stem borer, green bug/aphid, shoot fly, midge, head bug, and chinch bug, as well as grain hardiness and stover quality. The priority traits have been identified as drought, Striga, shoot fly, and downy mildew resistance (Witcombe and Duncan 1994).

The most fundamental step required for a detailed genetic study and marker-assisted breeding approach in any crop is the construction of linkage maps (Tanksley et al. 1989). With DNA marker technology, screening the plants using several markers for different pathogens simultaneously is possible without the need to inoculate the pathogens ( $\mathrm{Lu} \mathrm{1994).} \mathrm{However,} \mathrm{expression} \mathrm{of} \mathrm{such}$ resistance genes under variable field environments needs to be tested. Sorghum genome mapping based on DNA markers began in the early 1990s, and since then, many sorghum linkage maps have been constructed (Subudhi and Nguyen 2000, for review). Mapping of genes/QTL of agronomic importance, such as grain yield components, drought and cold tolerance, photoperiod response, resistance to shoot fly, stem borer and head bug, downy mildew, grain mold, and Striga, is described below. 


\subsection{Grain Yield Component Traits}

Breeding for grain yield per se is difficult as it has low heritability and is governed by polygenes. Little is known about the number and location of genes and their interactive effects on the expression of the component traits. High-density DNA marker maps provide this opportunity by making it possible to identify, map, and measure their effects by detecting QTL. Considerable progress has been made in this direction, and several yield components, such as kernel weight panicle ${ }^{-1}$, threshing $(\%)$, dehulling yield (\%), panicle length, tiller number, flowering or maturity, number of seed branches panicle ${ }^{-1}, 100 / 1000$ kernel weight, number of kernel panicle ${ }^{-1}$, and seed size, have been mapped (Lin et al. 1995; Pereira et al. 1995; Paterson et al. 1998; Rami et al. 1998; Crasta et al. 1999; Deu et al. 2000; Hart et al. 2002). Grain quality attributes like kernel flouriness, kernel friability, kernel hardiness, amylose content (\%), protein content, and lipid content (\%); fodder quality traits like stay-green; and juicy mid-rib have also been mapped (Tuinsta et al. 1996, 1997; Rami et al. 1998; Crasta et al. 1999; Deu et al. 2000; Subudhi et al. 2000; Tao et al. 2000; Xu et al. 2000; Haussmann et al. 2002). Depending on their relative effects and position, many QTL could be used as targets for marker-assisted selection and provide opportunity for accelerating breeding programs (Subudhi and Nguyen 2000).

\subsection{Drought Tolerance}

QTL studies have identified several genomic regions of sorghum associated with pre- and postflowering drought tolerance (Tuinsta et al. 1996, 1997, 1998; Crasta et al. 1999; Ejeta et al. 2000; Xu et al. 2000; Kebede et al. 2001). The molecular genetic analysis of QTL influencing staygreen trait, an important postflowering drought resistance, resulted in the identification of up to four QTL (Tao et al. 2000; Xu et al. 2000; Haussmann et al. 2002). Three of the four stay-green QTL showed consistency across different genetic backgrounds and environments, with the QTL Stg-2 expected to increase our understanding of stay-green trait, leading to either marker-assisted introgression of this QTL into an elite agronomic background or map-based cloning to genetically engineer this locus into improved cultivars (Subudhi et al. 2000).

ICRISAT recently mapped several new QTL for the drought tolerance/stay-green trait from two Striga resistance mapping populations derived from an agronomically elite, Striga-susceptible, staygreen parent E 36-1 that was not detected in previous studies based on sources B 35 and SC 5. To date, there are now three available stay-green sources (B 35, SC 56, and E 36-1) for which QTL have been mapped and identified on all 10 sorghum linkage groups. ICRISAT has initiated a markerassisted backcross program to introgress QTL for the stay-green trait from sources B 35 and E 361 into a diverse range of farmer-accepted sorghum cultivars adapted to diverse agroecologies in tropical Asia, Africa, and Latin America, with lines developed from this marker-assisted backcross program available shortly (ICRISAT 2002).

\subsection{Cold Tolerance}

Tolerance to early-season cold temperature is needed in much of the sorghum production areas of the U.S. Important advantages of this trait are attributed to seedling vigor, resulting in greater biomass and grain yield in cold and dry environments. Studies of Ejeta et al. (2000) suggest the presence of undetected QTL for early-season cold tolerance, highlighting the need for exhaustive detection of all relevant QTL by generating a series of well-controlled and -characterized phenotypic data.

\subsection{Striga Resistance}

Efforts are currently under way to identify and map genes for qualitative and quantitative resistance to Striga in three sorghum mapping populations derived from three crosses (Bennetzen 
et al. 2000; Ejeta et al. 2000; Haussmann et al. 2000c). By generating a dense linkage map using RFLP markers, Ejeta et al. (2000) were able to map the locus for one of the better-characterized mechanisms of resistance to Striga, viz., the low germination stimulant (lgs). They also placed a putative QTL for Striga resistance using phenotypic data from field evaluation of mapping population against Striga hermonthica and Striga asiatica. Single-marker analysis detected six QTL for resistance to $S$. hermonthica (accounted for $37 \%$ of the variation in resistance) and five QTL for resistance to $S$. asiatica (accounted for $49 \%$ of the variation in resistance).

Three QTL for Striga resistance from source N 13 have been identified that offer some degree of stability across subsets of the mapping populations and $S$. hermonthica strains of the parasitic weed from Eastern and Western Africa in a collaborative study between ICRISAT and the University of Hohenheim, Germany. However, map coverage is incomplete, and the single recessive gene for low levels of Striga seed germination stimulant does not yet cosegregate with any of the 10molecular marker-based linkage groups. Attempts are under way to extend the linkage maps of these two populations before completing QTL analysis while also initiating marker-assisted backcross transfer of the three resistance QTL from the source to a number of farmer-accepted sorghum cultivars of African origin (ICRISAT 2002).

The identification of individual genes or QTL for Striga resistance and their transfer into adapted cultivars will also allow the evaluation of any costs of Striga resistance, i.e., whether resistance is associated with any yield drag. Such costs of resistance might have been one of the reasons for slow breeding process in the past (Haussmann et al. 2000b).

\subsection{Photoperiod Response}

Photoperiod sensitivity appears to be a key feature matching flowering time to the length of the rainy season, and it plays an important role in securing the level and quality of harvest (Deu et al. 2000). Photoperiod response in cereals is determined by three main components (Major 1980): (1) basic vegetative phase (BVP) - defined as the shortest possible time for floral initiation when the plants are not responsive to changes in photoperiod; (2) photoperiod sensitivity (PS) - which expresses the varietal linear response to flowering time as plants respond to day-length changes; and (3) minimum optimal photoperiod (MOP) — defined as the photoperiod threshold beyond which the vegetative period is influenced by changes in day length.

Four major gene loci controlling flowering time have been identified in sorghum $\left(M a_{1}\right.$ to $\left.M a_{4}\right)$ (Quinby 1973). Recently, Aydin et al. (1997) showed that other maturity loci $\left(M A_{5}\right.$ and $\left.M A_{6}\right)$ might be involved in floral initiation of ultralate sorghum genotypes in the U.S. Lin et al. (1995) also identified another QTL for flowering time that is located on linkage group $\mathbf{H}$ of the linkage map described by Pereira et al. (1994). The genotypes involved in these studies were day-neutral and quantitatively short-day sorghums able to flower in the U.S. In more photoperiod-sensitive sorghum, one QTL has been detected on linkage group $\mathrm{H}$ for PS that explained $18 \%$ of total phenotypic variation. A second QTL was detected on the same linkage group for the direct measurement of photoperiod response (Trouche et al. 1998). QTL have also been detected and mapped for BVP and PS components of photoperiod response (Deu et al. 2000).

\subsection{Disease Resistance Traits}

11.8.2.1.6.1 Grain Mold - It is unlikely that traditional breeding methods will achieve highyielding, bold, white-grained sorghum with complete protection against grain mold (Reddy et al. 2000). New biotechnology techniques such as QTL analyses and marker-assisted selection provide new opportunities to enhance grain mold resistance. To date, 12 QTL have been detected that explain 10 to $33.8 \%$ of phenotypic variation in grain mold incidence; however, these QTL are unstable over different environmental conditions, indicating that genotype by environment interaction is critical in grain mold resistance (Rami et al. 1998; Rooney and Klein 2000; Klein et al. 
2001). While two grain mold QTL are related to phenotypic or kernal traits, the remaining three QTL were not associated; however, several possible traits that influence these QTL were predicted, including higher levels of antifungal proteins in resistant compared to susceptible lines (RodriguezHerrera et al. 1999; Rooney and Klein 2000).

11.8.2.1.6.2 Downy Mildew - Existing techniques for breeding varieties with resistance to the three pathotypes of downy mildew (Peronosclerospora sorghi (Weston and Uppal) C.G. Shaw) involve screening varieties after inoculation with the pathogen (Craig 1987; Sifuentes and Frederiksen 1988). Although this technique is excellent, it is costly and time-consuming and depends upon suitable environmental conditions for accuracy (Gowda et al. 1994).

The availability of tightly linked genetic markers for resistance genes will permit multigenic resistance to downy mildew. RFLP markers linked to different resistance genes were identified in the mid-1990s, and using marker-assisted selection (MAS), it should be possible to pyramid these genes to confer resistance to the three downy mildew pathotypes into agronomically acceptable cultivars (Gowda et al. 1994, 1995; Magill et al. 1997; Thakur et al. 1997).

Anthracnose (Colletotrichum graminicola) and head smut (Sporosorium reilianum) are globally important diseases for which RFLP markers closely linked to resistance genes have been identified. MAS will make possible the introgression of these resistance genes into agronomically elite cultivars (Oh et al. 1993; Rosenow 1994). Charcoal stalk rot is important in the postrainy season sorghum in India and other countries and is closely related to soil moisture deficit only during the grain fill stage. Considerable progress has been made toward charcoal stalk rot resistance (Rosenow 1994).

\subsection{Insect Resistance Traits}

11.8.2.1.7.1 Shoot Fly Resistance - Nonavailability of sources with absolute resistance to shoot fly in cultivated sorghum, coupled with the complex nature of the inheritance, has resulted in slow and inefficient progress in shoot fly resistance breeding using conventional approaches. The identification of genomic regions for each of the known components of shoot fly resistance, as well as markers tightly linked to these regions, will allow MAS breeding or map-based cloning to introgress or incorporate disease resistance genes into elite cultivars. Sajjanar (2002) identified eight QTL for shoot fly resistance components, with one major QTL for glossiness (phenotypic expression of 34.3 to $46.5 \%$ in the three screening environments, with highest expression in postrainy season) identified that was linked with dead hearts (\%) under high shoot fly pressure. This QTL may be a useful target for MAS for shoot fly resistance in sorghum.

At ICRISAT, QTL mapping is under way for shoot fly resistance using recombinant inbred line (RIL) populations, with a linkage map with reasonable genome coverage constructed identifying six QTL in at least two screening environments. The phenotypic variance explained by each of these QTL ranged from $62.9 \%$ for glossiness to $4.5 \%$ for seedling vigor, offering potential in MAS breeding for resistance (ICRISAT 2002).

11.8.2.1.7.2 Sorghum Midge Resistance - A poor understanding of resistance to sorghum midge has slowed progress in host plant resistance to sorghum midge, as there are three different mechanisms of midge resistance involved in insect-host plant interactions: antixenosis, antibiosis, and tolerance (Kogan and Ortman 1978). Very recently, QTL associated with two of the mechanisms of midge resistance, antixenosis and antibiosis, were identified from a relatively large recombinant inbred (RI) population through accurate glass house screening (Tao et al. 2003). Two regions on separate linkage groups (A\&G) were associated with antixenosis and explained $34.5 \%$ of the variation in the difference of egg and pupal counts in the RI population. The identification of genes for different mechanisms of midge resistance will be particularly useful for exploring new sources of midge resistance and for gene pyramiding of different mechanisms in sorghum breeding through marker-assisted selection. 
The only program to find molecular markers putatively linked with midge resistance is in Australia, with two QTL explaining $27 \%$ of the variation in ovipositional antixenosis (nonpreference), while one QTL explained $34.5 \%$ of variation in antibiosis from a study of a RIL population (Tao et al. 1996, Henzell et al. 2002).

11.8.2.1.7.3 Sorghum-Spotted Stem Borer Resistance - QTL mapping is currently under way for resistance to several species of sorghum stem borers using RILs derived from three populations, with mapping of SSRs achieved with a reasonably good coverage of the sorghum genome (ICRISAT 2002).

\subsubsection{Genetic Transformation Technology}

The process of introduction, integration, and expression of foreign genes in the host is called genetic transformation. Combined use of recombinant DNA technology, gene transfer methods, and tissue culture techniques has led to the efficient production of transgenics in a wide array of crop plants. Unlike conventional plant breeding, in transgenesis, only the cloned genes of agronomic importance are introduced into the plants without linkage drag from the donor. This approach has the potential to serve as an effective means of removing certain specific defects of an otherwise well-adapted cultivar, which is difficult using conventional breeding approaches (Chahal and Gosal 2002).

Compared to all other major food crops, sorghum transformation is in its infancy, with much technical progress yet to be achieved (Seetharama et al. 2003). Successful transformation of sorghum was first achieved in the early 1990s, with highly advanced transformation technology now available that is capable of transforming at least $150 \mathrm{kbp}$ of foreign DNA into the sorghum genome (Hamilton et al. 1996; Seetharama et al. 2003). At ICRISAT, sorghum transformation has been achieved and efforts are continuing to develop procedures for Agrobacterium-mediated transformation. Transgenic sorghums have been developed with resistance to stem borer that have been molecularly characterized and are undergoing insect bioassays. Preliminary results have indicated that 9 of 11 transgenic plants expressed a good level of protection against stem borer damage (ICRISAT 2002). Although transgenic sorghum has been developed, the absence of pleiotropic effects must be assured, and consideration of biosafety issues is important before useful transgenic plants can be commercialized.

\subsubsection{Transgenics and Conventional Breeding Integrated Technology}

Hybrid seed will be the final delivery vehicle of transgenic technology to the farmers, and as such, integration of conventional breeding with transgenic research will be required (Seetharama et al. 2003). A case study with special reference to sorghum is detailed in Reddy and Seetharama (2001). Hybrid sorghum production offers an opportunity to separately pyramid two sets of traits in different parents: the efficiency of this approach is not yet adequately tested in any crop; however, it is likely that most of the transgenes will be first introduced into the proper female parent (Aline), and most of the natural resistance may be bred into the male set (restorer lines).

The questions related to and public acceptance of transgenic crops are not unique to sorghum. Considering the fact that sorghum is a poor man's food crop and that only a small proportion of production enters the global market, public institutions will have a greater say and responsibility in this respect (Reddy et al. 2001). Conversely, sorghum farmers in developing countries may not be able to use transgenic sorghum, as the focus of transgenic research may be toward industrial and export purposes. All these issues have to be considered on a case-by-case basis, and once the extent of economic and social benefits is weighed against the acceptable magnitude of risk, if any, decisions will be made. 


\subsection{SUMMARY}

Sorghum, the fourth major cereal crop of the world in production and fifth in acreage after wheat, rice, maize, and barley, is mostly grown by resource-limited farmers under minimal/traditional management conditions in the semiarid tropics of the world as a subsistence crop, thereby recording low productivity compared to other developed regions of the world. The yield and quality of sorghum produce are influenced by a wide array of biotic (shoot fly, stem borer, head bug, aphid, armyworms, and locusts among insects; grain mold, charcoal rot, downy mildew, anthracnose, rust, and leaf blight among diseases; and S. asiatica, $S$. densiflora, and S. hermonthica, a parasitic weed) and abiotic (problematic soils like saline and acidic, temperature extremities and drought) constraints.

Sorghum, with its primary center of origin in Africa and secondary center of origin in the Indian subcontinent, probably domesticated in the northeast quadrant of Africa, from where it spread to India, China, the Middle East, and Europe soon after its domestication. ICRISAT, which is a major repository of world sorghum germplasm, has the responsibility of preservation, maintenance, characterization, and distribution.

The genetic variability available in cultivated races and their wild relatives is extensive, and the extreme types are so different as to appear as separate species. The major germplasm sources utilized so far in varietal improvement include temperate lines from the U.S., zera zera lines from Ethiopia and Sudan, and some lines of Indian origin.

High-lysine sorghum lines from Ethiopia were used in the breeding program for transferring this trait to a desirable agronomic background. Conversion of tall, late, or nonflowering (in the U.S.) sorghum germplasm from tropics into short, early-photoperiod-insensitive forms jointly by the Texas Agricultural Experiment Station and USDA, and conversion of tall, late-flowering zera zera (from the Ethiopia-Sudan border) landraces and kauras and guineenses (from Nigeria) by ICRISAT resulted in enhanced use of exotic sorghum germplasm, broadening of genetic diversity, and provision of new sources of desirable traits to sorghum researchers. The breeding materials so far exploited rather extensively in sorghum improvement programs in India, other tropical areas of the world, and the southern U.S. belonged to derivatives of the zera zera group. Extensive use of the zera zera group of converted sorghums has made a major contribution to disease resistance, yield potential, and grain quality of U.S. hybrid sorghums. In the U.S., Kaura (origin: Nigeria), African introductions, and the source of yellow endosperm were extensively used in sorghum improvement prior to the development of the conversion programs.

Two types of male sterility, GMS and CMS, are widely used in sorghum improvement programs. Of the several GMS-inducing alleles (such as $m s_{1}, m s_{2}, m s_{3}, m s_{4}, m s_{5}, m s_{6}, m s_{7}$, and $a l$ ), $m s_{3}$ followed by $m s_{7}$ have been widely used in population improvement, as they are stable over a range of environments. Of the several different sources of CMS, only $A_{l}$ cytoplasm has been extensively used in the development of commercial sorghum hybrids worldwide. However, recent evidences point out the potential of $A_{2}$ cytoplasm, especially in the development of hybrids. Extensive research is under way for the development of $A_{2}$ cytoplasm-based hybrids at ICRISAT and through Indian programs. In China, $A_{2}$ cytoplasm-based hybrids are already in commercial cultivation. Breeding methods used in sorghum improvement world over are those developed for self-pollinated crops, such as pure line selection, pedigree breeding, backcross breeding, population improvement (using GMS), and hybrid breeding.

Conventional approaches to enhance resistance to diseases such as grain mold, downy mildew, anthracnose, and head smut; insect pests like shoot fly and stem borer; endemic weed, Striga; and terminal drought have met with partial success. The identification of genomic regions affecting each of these resistance traits as well as markers tightly linked to these regions would greatly facilitate the exploitation of MAS breeding or map-based cloning to introgress or incorporate resistance genes into elite cultivars. While considerable progress has been made in combining enhanced levels of host plant resistance (HPR) to sorghum midge with local adaptation in the 
breeding programs at ICRISAT, Texas A\&M University, and in Australia through conventional breeding approaches, application of MAS is further expected to hasten this progress.

While attempts to enhance salinity tolerance of sorghum in saline areas are limited, much progress has been achieved in breeding sorghum for soil acidity tolerance with and without $\mathrm{Al}^{3+}$ toxicity. Future breeding programs should aim at specific adaptations in view of significant genotype $\times \mathrm{Al}^{3+}$ toxicity interaction variation and variation in $\mathrm{Al}^{3+}$ saturation from location to location. Further, the possibility of different resistance mechanisms due to varying levels of $\mathrm{Al}^{3+}$ saturation necessitates the study of resistance mechanisms and their genetics in the selected sorghum lines. The considerable variability in soil salinity levels both spatially and temporally, and with much variation within the same plot, also warrants breeding for wide adaptation for salinity tolerance in sorghum.

The identification of natural, exceptionally'high lysine Ethiopian mutants from the world sorghum collection, a chemically induced high-lysine mutant, and, recently, a sorghum line with high protein digestibility levels in plump grain background surpassing that of maize, as well as identification of molecular markers linked to high protein digestibility or high lysine in high-lysine sorghum lines, facilitated the prospects for combining high protein quality and protein digestibility with grain yield.

It is expected that there will be greater use of genomic tools for germplasm management and gene manipulation through marker-assisted selection, as more and more useful traits are tagged in the near future. Sorghum, as a drought-tolerant crop species with a small genome size, is an excellent model for the investigation of genes involved in drought tolerance and plant adaptation to harsh climate conditions. It can be transformed with a number of candidate genes to enhance resistance to biotic and abiotic stress factors. With the advent of sophisticated transformation technology, it should be possible to transfer resistance genes from the secondary gene pool into cultivated sorghums, which was not possible hitherto due to crossing barriers. Enormous potential exists for further improvement of grain yield and boldness with high levels of $\mathrm{Fe}, \mathrm{Zn}$, and vitamin $\mathrm{A}$, resistance to grain mold and shoot fly, and tolerance to abiotic stresses, including problematic soils, considering the vast variability left untapped in this crop following specific adaptation approaches.

\section{ACKNOWLEDGMENTS}

A financial grant from Suri Sehgal Foundation, India, in partial support of this work and encouragement received from Dr. C.L.L. Gowda, Global Theme Leader, Crop Improvement, ICRISAT, to carry out this work are gratefully acknowledged. We are indebted to Dr. Sally Dillon, Australian Tropical Crops and Forages Collection, Queensland Department of Primary Industries and Fisheries, Australia, for his critical review and editing of the manuscript and providing invaluable suggestions and comments to improve the quality of the manusript.

\section{REFERENCES}

Aboubacar, A., Axtell, J.D., Huang, C.P., and Hamaker, B.R. 2002. A rapid protein digestibility assay for identifying highly digestible sorghum lines. Cereal Chem. 78: 160-165.

Adamou, M., Gourley, L.M., Watson, C.E., Mclean, S.D., and Goggo, A.S. 1992. Evaluation of combining ability of acid soil tolerant sorghum germplasm in Niger. In Agronomy Abstracts, November 1-6, Minneapolis, p. 88.

Ahlrichs, S.L, Duncan, R.R., Ejeta, G.E., Hill, P.P., Baligar, V.C., Wright, R.J., and Hanna, W.W. 1991. Pearl millet and sorghum tolerance to aluminum in acid soil. In Plant Soil Interactions at Low pH, R.J. Wright, Ed. Kluwer Academic Publishers, Dordrecht, The Netherlands, p. 197.

Ahnert, D., Lee, M., Austin, D.F., Woodman, W.L., Openshaw, S.J., Smith, J.S.C., Porter, K., and Dalton. 1996. Genetic diversity among the elite Sorghum inbred lines assessed with DNA markers and pedigree information. Crop Sci. 36: 1385-1392. 
Aldrich, P.R., Doebley, J., Schertz, K.F., and Stec, A. 1992. Patterns of allozyme variation in cultivated and wild Sorghum bicolor. Theor. Appl. Genet. 85: 451-460.

Anonymous. 1967. Bird resistance sorghum where damage to corn is severe. Crops Soils 19: 21-22.

Arti, M. 1993. Water-soluble proteins of Indian sorghum cultivars. Sorghum Newsl. 34: 53.

Arunachalam, V., Prabhu, K.V., and Su jatha, V. 1998. Multivariate methods of quantitative evaluation of crop improvement: conventional and molecular approaches revisited. In Crop Productivity and Sustainability: Shaping the Future, Proceedings of 2nd International Crop Science Congress, New Delhi, India, V.L. Chopra, R.B. Singh, and A. Varma, Eds., pp. 793-807.

Asante, S.A. 1995. Sorghum utility and utilization. Afr. Crop Sci. J. 3: 231-240.

$\mathrm{Au}$, P. 1979. Study of Fermentation of Grain Sorghum to Improve Its Amino Acid and Vitamin Content. M.S thesis, University of Missouri-Columbia, Columbia.

Austin, R.B. 1993. Augmenting yield-based selection. In Plant Breeding Principles and Prospects, M.D. Hayward, N.O. Bosemark, and I. Romagosa, Eds. Chapman \& Hall, London, pp. 391-405.

Axtell, J.D. 2001. Breeding Sorghum for Increased Nutritional Value, 2001 Annual Report. INTSORMIL Sorghum/Millet Collaborative Support Program (CRSP), pp. 67-73.

Axtell, J.D., Van Scoyoc, S.W., Christensen, P.J., and Ejeta, C. 1979. Current status of protein quality improvement in grain sorghum. In Seed Protein Improvement in Cereals and Grain Legumes. IAEA, Vienna, pp. 357-366.

Ayana, A. and Bekele, E. 1999. Multivariate analysis of morphological variation in sorghum [Sorghum bicolor (L.) Moench] germplasm from Ethiopia and Eritrea. Genet. Resour: Crop Evol. 46: 273-284.

Ayana, A., Bekele, E., and Bryngelsson, T. 2000a. Genetic variation in wild sorghum [Sorghum bicolor spp. verticilliflorum (L.) Moench] germplasm from Ethiopia assessed by random amplified polymorphic DNA (RAPD). Hereditas 3: 249-254.

Ayana, A., Bekele, E., and Bryngelsson, T. 2000b. Genetic variation of Ethiopian and Eritrean sorghum [Sorghum bicolor (L.) Moench] germplasm assessed by random amplified polymorphism DNA (RAPD). Genet. Resour. Crop Evol. 47: 471-482.

Aydin, S., Rooney, W.L., and Miller, F.R. 1997. Identification and characterization of the Ma5 and Ma6 maturity loci in sorghum. In Proceedings of the Intermational Conference on Genetic Improvement of Sorghum and Pearl Millet, Lubbock, TX, September 22-27, 1996, pp. 641-642.

Ayyangar, G.N.R. and Ponnaiya, B.W.X. 1939. The occurrence and inheritance of earheads with empty anther sacs in sorghum. Curr. Sci. 8: 116.

Azhar, F.M. and McNeilly, T. 1987. Variability for salt tolerance in Sorghum bicolor (L.) Moench under hydroponic condition. J. Agron. Crop Sci. 159: 269-277.

Azhar, F.M. and McNeilly, T. 1989. Heritability estimates of variation for $\mathrm{NaCl}$ tolerance in Sorghum bicolor (L.) Moench seedlings. Euphytica 43: 69-72.

Badi, S., Pedersen, B., Monowar, L., and Eggum, B.O. 1990. The nutritive value of new and traditional sorghum and millet foods for Sudan. Plant Foods Hum. Nutr: 40: 5-19.

Banziger, M. and Long, J. 2000. The potential for increasing the iron and zinc density of maize through plantbreeding. Food Nutr. Bull. 21: 397-400.

Barthate, K.K., Patil, J.V., and Thete, R.V. 2000. Genetic divergence in sorghum under different environments. Indian J. Agric. Res. 34: 85-90.

Bebawi, F.F. 1981. Response of sorghum cultivars and Striga population to nitrogen fertilization. Plant Soil 59: 261-267.

Bennetzen, J.L., Gong, F., Xu, J., Newton, C., and de Oliveira, A.C. 2000. The study and engineering of resistance to parasitic weed Striga in rice, sorghum and maize. In Breeding for Striga Resistance in Cereals, Proceedings of a Workshop, B.I.G. Haussmann, D.E. Hess, M.L. Koyama, L. Grivet, H.F.W. Rattunde, and H.H. Geiger, Eds., Ibadan, Nigeria, August 18-20, 1999, pp. 197-205.

Blum, A. 1983. Genetic and physiological relationships in plant breeding for drought resistance. Agric. Water Manage. 7: 195-202.

Blum, A. 1987. Genetic and environmental considerations in the improvement of drought stress avoidance in sorghum. In Food Grain Production in Semi-Arid Africa, Proceedings of the Intermational Drought Symposium, Nairobi, Kenya, May 19-23, 1983, pp. 91-99.

Bonhert, H.J., Nelson, D.E., and Jenson, R.G. 1995. Adaptations to environment stresses. Plant Cell 7: 1099-1111. 
Borrell, A.K., Bidinger, F.R., and Sunitha, K. 1999. Stay-green associated with yield in recombinant inbred sorghum lines varying in rate of leaf senescence. Int. Sorghum Millets Newsl. 40: 31-33.

Borrell, A.K. and Douglas, A.C.L. 1997. Maintaining green leaf area in grain sorghum increased nitrogen uptake under post-anthesis drought. Int. Sorghum Millets Newsl. 38: 89-91.

Borrell, A.K. and Hammar, G.L. 2000. Nitrogen dynamics and the physiological basis of stay-green in sorghum. Crop Sci. 40: 1295-1307.

Borrell, A.K., Hammar, G.L., and Douglas, A.C.L. 2000a. Does maintaining green leaf area in sorghum improve yield under drought? I. Leaf growth and senescence. Crop Sci. 40: 1026-1037.

Borrell, A.K., Hammar, G.L., and Henzell, R.O. 2000b. Does maintaining green leaf area in sorghum improve yield under drought? II. Dry matter production and yield. Crop Sci. 40: 1037-1048.

Bouis, H.E., Graham, R.D., and Welch, R.M. 2000. The Consultative Group on International Agricultural Research (CGIAR) micro nutrient project: justification and objectives. Food Nutr. Bull. 21: 374-381.

Bramel-Cox, P.J., Lauver, M.A., and Witt, M.E. 1990. Potential gain from selection in grain sorghum for higher protein digestibility. Crop Sci. 30: 521-524.

Bramel-Cox, P.J., Kumar, K.A., Hancock, J.D., and Andrews, D.J. 1995. Sorghum and millets for forage and feed. In Sorghum and Millets: Chemistry and Technology, D.A.V. Dendy, Ed. American Association of Cereal Chemists, St. Paul, MN, pp. 325-364.

Brown, A.H.D. 1989. The case for core collection. In The Use of Plant Genetic Resources, A.H.D. Brown, O.H. Frankel, D.R. Marshall, and J.T. Williams, Eds. Cambridge University Press, Cambridge, U.K., pp. 136-156.

Brown, M.S. 1943. Haploid plants in sorghum. J. Hered. 34: 163-166.

Bulter, L.G. 1990a. Tannins and Other Phenols: Effects on Sorghum Production and Utilization, INTSORMIL Annual Report (a technical research report of the grain sorghum/pearl millet collaborative research support program (CRSP)). CRSP, Lincoln, NE, pp. 140-144.

Bulter, L.G. 1990b. The nature and amelioration of the antinutritional effects of tannins in sorghum grain. In Sorghum Nutritional Quality: Proceedings of an International Conference, G. Ejeta, E.T. Mertz, L.W. Rooney, R. L'Schaffert, and J. Yohe, Eds., Purdue University, West Lafayette, IN, February 26-March 1, pp. 191-205.

Burner, D.K., Kling, J.G., and Singh, B.B. 1995. Striga research and control, a perspective from Africa. Plant Dis. 79: 652-660.

Calhoun, D.S., Gebeyehu, C., Miranda, A., Rajaram, S., and Van Ginkel, M. 1994. Choosing evaluation environments to increase grain yield under drought conditions. Crop Sci. 34: 673-678.

Celarier, R.P. 1959. Cytotaxonomy of the Andropogonea. III. Sub-tribe sorgheae, genus sorghum. Cytologia 23: $395-418$.

Chahal, G.S. and Gosal, S.S. 2002. Principles and Procedures of Plant Breeding: Biotechnological and Conventional Approaches. Narosa Publishing House, New Delhi, p. 486.

Chandel, K.P.S. and Paroda, R.S. 2000. Status of Plant Genetic Resources Conservation and Utilization in Asia-Pacific Region, Regional Synthesis Report 32, Asia-Pacific Association of Agricultural Institutions, FAO Regional Office for Asia and the Pacific, Bangkok.

Chandrasekharaiah, S.R., Murty, B.R., and Arunachalam, V. 1969. Multivariate analysis of divergence in the genus Eu-sorghum. Proc. Natl. Inst. Sci. India B 35: 172-195.

Chavan, J.K., Kadam, S.S., and Salunkhe, D.K. 1980. Changes in tannin free amino acids, reducing sugars, and starch during seed germination of low and high tannin cultivars of sorghum. J. Food Sci. 46: 638-639.

Cherney, J.H. 1990. Normal and brown-midrib mutations in relation to improved ligno cellulose utilization. In Microbial and Plant Opportunities to Improve Lignocellulose Utilization by Ruminants, D.E. Akin and L.G. Lungdahl, Eds. Elsevier, Amsterdam, pp. 205-214.

Cherney, J.H., Cherney, D.J.R., Akin, D.E., and Axtell, J.D. 1991. Potential of brown-midrib, low lignin mutants for improving forage quality. Adv. Agron. 46: 157-198.

Chinna, B.S. and Phul, P.S. 1986. Heterosis and combining ability studies for protein, lysine and tryptophan in sorghum [Sorghum bicolor (L) Moench]. Genet. Agrar. 40: 405-414.

Chintu, E.M. 2000. Development of sorghum varieties through participatory plant breeding in Malawi. Int. Sorghum Newsl. 41: 23-24. 
Chittenden, L.M., Schertz, K.F., Lin, V.R., Wing, R.A., and Paterson, A.H. 1994. A detailed RFLP map of Sorghum bicolor $\times S$. propinquum, suitable for high density mapping, suggests ancestral duplication of sorghum chromosomes or chromosomal segments. Theor. Appl. Genet. 87: 925-933.

Christiansen, M.N. and Lewis, C.F. 1982. Breeding Plants for Less Favourable Environments. John Wiley \& Sons, New York.

Clayton, W.D. 1961. Proposal to conserve the generic name Sorghum Moench (Gramineae) versus Sorghum adans (Gramineae). Taxonomy 10: 242.

Clayton, W.D. and Renvoize, S.A. 1986. Genera Graminum Grasses of the World, Kew Bulletin Addition Series XIII. Royal Botanic Gardens, Kew, London, pp. 338-345.

Comstock, R.E. and Robinson, H.F. 1952. Genetic parameters, their estimation and significance. In Proceedings of the Sixth Intermational Grass Lands Congress, pp. 284-291.

Craig, J. 1987. Tiered temperature system for producing and storing conidia of Peronosclerospra sorghi. Plant Dis. 71: 365-368.

Crasta, O.R., Xu, W., Rosenow, D.T., Mullet, J.E., and Nguyen, H.T. 1999. Mapping of post-flowering drought resistance traits in grain sorghum: association of QTLs influencing premature senesecence and maturing. Mol. Gen. Genet. 262: 579-588.

Cress, C.E. 1966. Heterosis of the hybrid related to gene frequency differences between two populations. Genetics 53: 269-274.

Cui, Y.X., Xu, G.W., Magill, C.W., Schertz, K.F., and Hart, G.E. 1995. RFLP based assay of Sorghum bicolor (L.) Moench genetic diversity. Theor. Appl. Genet. 90: 787-796.

Dahlberg, J.A. 2000. Classification and characterization of sorghum. In Sorghum, Origin, History, Technology and Production, Wiley Series in Crop Science, C.W. Smith and R.A. Frederiksen, Eds. John Wiley \& Sons, New York, pp. 99-130.

Dahlberg, J.A., Hash, C.T., Kresovich, S., Maunder, B., and Gilbert, M. 1997. Sorghum and pearl millet genetic resources utilization. In Proceedings of the International Conference on Genetic Improvement of Sorghum and Pearl Millet, September 22-27, 1996, Lubbock, TX, pp. 42-54.

Dahlberg, J.A. and Spinks, M.S. 1995. Current status of the U.S. sorghum germplasm collection. Int. Sorghum Millets Newsl. 36: 4-12.

Damania, A.B. 2002. The Hindustan centre of origin of important plants. Asian Agri-Hist. 6: 333-341.

de Andrade Lima, M.M., Maciel, G.A., Tabosa, J.N., Tavares, J.A., and Neto, C. de A. 1992. Advanced grain sorghum trial for aluminium tolerance. Sorghum Newsl. 33: 58.

de la Rosa Ibarra, M. and Maiti, R.K. 1994. Morphological and biochemical basis of resistance of glossy sorghum to salinity at seedling stage. Int. Sorghum Millets Newsl. 35: 118-119.

de Wet, J.M.J. 1977. Domestication of African cereals. Afr. Econ. Hist. 3: 15.

de Wet, J.M.J. and Harlan, J.R. 1971. The origin and domestication of Sorghum bicolor. Econ. Bot. 25 : $128-135$.

de Wet, J.M.J., Harlan, J.R., and Price, E.G. 1976. Variability in Sorghum bicolor. In Origins of African Plant Domestication, J.R. Harlan, J.M.J. de Wet, and A.B.C. Stemler, Eds. The Mountain Press, The Hague, pp. $453-463$.

de Wet, J.M.J. and Huckabay, J.P. 1967. The origin of Sorghum bicolor. II. Distribution and domestication. Evolution 211: 787-802.

Dean, R.E., Dahlberg, J.A., Hopkins, M.S., Mitchell, S.E., and Kresovich, S. 1999. Genetic redundancy and diversity among 'orange' accessions in the U.S. National Sorghum collection as assessed with simple sequence repeat (SSR) markers. Crop Sci. 39: 1215-1221.

Deosthale, Y.G., Mohan, V.S., and Rao, V. 1970. Varietal differences in protein, lysine and leusine content of grain sorghum. J. Agric. Food Chem. 18: $644-646$.

Deosthale, Y.G., Nagarajan, V., and Vesweswar Rao, K. 1972. Some factors influencing the nutrient composition of sorghum grain. Indian J. Agric. Sci. 42: 100-108.

Deu, M., Grivet, L'Trouche, G., Barro, C., Ratnadass A., Diabate, M., Hamada, A., Fliedel, G., Rami, J.F., Grenier, C., Hamon, P., Glaszmann, J.C., and Chantereau, J. 2000. Use of molecular markers in the sorghum breeding program at CIRAD. In Application of Molecular Markers in Plant Breeding, training manual on seminar held at IITA, B.I.G. Haussmann, H.H. Greiger, D.E. Hess, C.T. Hash, and P. Bramel-Cox, Eds., Ibadan, Nigeria, August 16-17, 1999.

Deyoe, C.W., Shoup, F.K., Miller, G.D., Bathurst, J., Laing, D., Standford, P.E., and Murphy, L.S. 1970. Amino acid composition and energy value of immature sorghum grain. Cereal Chem. 47: 363-368. 
Doggett, H. 1988. Sorghum, 2nd ed. Longmans Scientific and Technical Publishers, London, U.K.

Doggett, H. 1962. Tetraploid hybrid sorghum. Nature 196: 755-756.

Doggett, H. 1965. The development of cultivated sorghum. In Crop Plant Evolution, I. Hutchinson, Ed. Cambridge University Press, Cambridge, U.K., pp. 50-69.

Doggett, H. 1970. Sorghum. Longmans Green, London.

Doggett, H. 1972. The important sorghum in East Africa. In Sorghum in the Seventies, N.G.P Rao and L.R. House, Eds. Oxford and IBH Publishing Co., New Delhi, pp. 47-59.

Doggett, H. 1984. Striga: its biology and control — an overview. In Striga: Biology and Control, E.S. Ayensu, H. Doggett, R.D. Keynes, J. Marton-Lefevre, L.J. Musselman, C. Parker, and A. Pickering, Eds. ICSU Press, Paris, p. 27.

Downes, R.W. 1972. Discussion: physiological aspects of sorghum adaptation In Sorghum in the Seventies, N.G.P Rao and L.R. House, Eds. Oxford and IBH Publishing Co., New Delhi, pp. 256-274.

Dufour, P., Grivet, L., D’Hont, A., Deu, M., Trouche, G., Glaszmann, J.C., and Haman, P. 1996. Comparative genetic mapping between duplicated segments on maize chromosomes 3 and 8 and homeologous regions in sorghum and sugarcane. Theor: Appl. Genet. 92: 1024-1030.

Duncan, R.R., Bramel-Cox, P.J., and Miller, F.R. 1991. Contributions of introduced sorghum germplasm to hybrid development in the U.S. In Use of Plant Introductions in Cultivar Development, Part 1, CSSA Special Publication 117, H.L. Shands and L.E. Wiesner, Eds. Crop Science Society of America, Madison, WI, pp. 69-102.

Duncan, R.R. and Dahlberg, J.A. 1993. Cross-reference of PI/IS/SC numbers from U.S. conversion program. Sorghum Newsl. 34: 72-80.

Eberhart, S.A. 1972. Techniques and methods for more efficient population improvement in sorghum. In Sorghum in the Seventies, N.G.P. Rao and L.R. House, Eds. Oxford and IBH Publishing Co., New Delhi, pp. 195-213.

Eberhart, S.A., Bramel-Cox, P.J., and Prasada Rao, K.E. 1997. Preserving genetic resources. In The Proceedings of the International Conference on Genetic Improvement of Sorghum and Pearl Millet, Lubbock, TX, September 22-27, 1996.

Ejeta, G. 1987. Breeding sorghum hybrids for irrigated and rainfed conditions in Sudan. In Food Grain Production in Semi-Arid Africa, Proceedings of the International Drought Symposium, Nairobi, Kenya, May 19-23, 1986, pp. 121-130.

Ejeta, G. and Axtell, J.D. 1990. Development of hard endosperm high lysine sorghum lines. In Sorghum Nutritional Quality, Proceodings of an International Conference, G. Ejeta et al., Eds., Purdue University, West Lafayette, IN, February 26-March 1, pp. 126-141.

Ejeta, G. and Bulter, L.G. 1993a. Host-parasite interactions throughout the Striga life cycle and their contributions to Striga resistance. Afr. Crops Sci. J. 1: 75-80.

Ejeta, G. and Bulter, L.G. 1993b. Host-plant resistant to Striga. In International Crop Science I, D.R. Buxton et al., Eds. International Crop Science Congress, Crop Science Society of America, Madison, WI, pp. 561-569.

Ejeta, G., Bulter, L.G., and Babiker, A.G. 1992. New Approaches to the Control of Striga, Striga Research at Purdue University, Research Bulletin 991. Agricultural Experiment Station, Purdue University, West Lafayette, IN, 1992.

Ejeta, G., Bulter, L.G., Hess, D.E., Obilana, T., and Reddy, B.V.S. 1997. Breeding for Striga resistance in sorghum. In Proceedings of the International Conference on Genetic Improvement of Sorghum and Pearl Millet, Lubbock, TX, September 22-27, 1996, pp. 504-516.

Ejeta, G., Bulter, L.G., Hess, D.E., and Vogler, R.K. 1991. Genetic and breeding strategies for Striga resistance in sorghum. In Proceedings of the Fifth Intermational Symposium on Parasitic Weeds, Ransom J.K. et al., Eds., Nairobi, Kenya, pp. 539-544.

Ejeta, G., Goldsbrough, P.B., Tunistra, M.R., Grote, E.M., Menkir, A., Ibrahim, Y., Cisse, N., Weerasuriya, Y., Melake-Berhan, A., and Shaner, C.A. 2000. Molecular marker applications in sorghum. In Application of Molecular Markers in Plant Breeding, training manual on seminar held at IITA, B.I.G. Haussmann, H.H. Geiger, D.E. Hess, C.T. Hash, and P. Bramel-Cox, Eds., Ibadan, Nigeria, August 16-17, 1999.

Endrizzi, J.E. and Morgan, D.T., Jr. 1955. Chromosomal interchanges and evidence for duplication in haploid Sorghum vulgare. J. Hered. 46: 201-208.

FAO. 1983. International Undertaking on Plant Genetic Resources. FAO of the United Nations, Rome. 
Fernandes, M.B., Castro, J.R., de Fernandes, V.L.B., Aquino, B.F., de Alves, J.S., and Gois, F.C. de. 1994. Evaluation of forage sorghum cultivars in salt affected soils of Rio Grande do Norte, Brazil. Pesquisa Agropecuaria Brasileira 29: 25-261.

Flores, C.I., Clark, R.B., Pedersen, J.F., and Gourley, L.M. 1991. Leaf mineral element concentrations in sorghum (Sorghum bicolor) hybrids and their parents grown at varied aluminium saturations on an ultisol. In Plant Soil Interactions at Low pH, R.J. Wright, V.C. Baligar, and R.P. Murrmann, Eds. Kluwer Academic Publishers, Dordrecht, The Netherlands, pp. 1095-1104.

Garber, E.D. 1950. Cytotaxonomy studies in the genus sorghum. Univ. Calif. Publ. Bot. 23: 283-362.

Gardner, C.O. 1972. Development of superior populations of sorghum and their role in breeding program. In Sorghum in the Seventies, N.G.P. Rao and L.R. House, Eds. Oxford and IBH Publishing Co., New Delhi, pp. 180-183.

Garrity, D.P., Sullivan, C.Y., and Ross, W.M. 1982. Alternative approaches to improving grain sorghum productivity under drought stress. In Drought Resistance in Crops with Emphasis in Rice. International Rice Research Institute, Manila, Philippines, pp. 339-356.

Gebrekidan, B. 1982. Utilization of germplasm in sorghum improvement. In Proceedings of the International Symposium on Sorghum, L.R. House, L.K. Mughogho, and J.M. Peacock, Eds., ICRISAT, Patancheru, India, November 2-7, 1981, 1: 335-345.

Geng, B.R. 1994. Study on some hereditary properties of sudangrass (Sorghum sudanense). Grass. China 3: 58-61.

Gomez, M.I., Islam-Faridi, M.N., Zwick, M.S., Czeschin, D.G., Jr., Wing, R.A., Stelly, D.M., and Price, J.H. 1998. Tetraploid nature of Sorghum bicolor (L.) Moench. J. Hered. 89: 188-190.

Gopal Reddy, G.N., Kameshwara Rao, N., Reddy, B.V.S., and Prasada Rao, K.E. 2002. Geographic distribution of basic and intermediate races in the world collection of sorghum germplasm. Int. Sorghum Millet Newsl. 43: 15-17.

Gopalan, C. and Srikantia, S.G. 1960. Leucine and pellagra. Lancet 1: 954-957.

Gourley, L.M. 1988. Breeding sorghum for acid soils of the humid tropics. In Africaland: Land Development and Management of Acid Soils in Africa II, M. Lathan, Ed. Inter Board for Soils Research and Management (IBSRAM), Bangkok, Thailand, pp. 261-273.

Gourley, L.M. and Lusk, J.W. 1978. Genetic parameters related to sorghum silage quality. J. Dairy Sci. 61: 1821-1827.

Gourley, L.M., Watson, C.E., Goggi, A.S., and Axtell, J.D. 1997b. Grain sorghum inbreds tolerant to tropical acid soils released as germplasm. Int. Sorghum Millets Newsl. 38: 93-94.

Gourley, L.M., Watson, C.E., Schaffert, R.E., and Payne, W.A. 1997a. Genetic resistance to soil chemical toxicities and deficiencies. In International Conference on Genetic Improvement of Sorghum and Pearl Millet, Lubbock, TX, September 22-27, 1996, pp. 461-480.

Gowda, B.T.S., Halaswamy, B.H., Seetharam, A., Virk, D.S., and Witcombe, J.R. 2000. Participatory approach in varietal improvement: a case study in finger millet in India. Curr. Sci. 79: 366-368.

Gowda, P.S.B., Magill, C.W., and Frederiksen, R.A. 1994. Tagging downy mildew resistance genes in sorghum. In Use of Molecular Markers in Sorghum and Pearl Millet Breeding for Developing Countries, Proceedings of an ODA Plant Sciences Research Program Conference, J.R. Witcombe and R.R. Duncan, Eds., Norwich, U.K., March 29-April 1, 1993.

Gowda, P.S.B., Xu, G.W., Frederiksen, R.A., and Magill, C.W. 1995. DNA markers for downy mildew resistance genes in sorghum. Genome 38: 823-826.

Graham, R.D., Senadhira, D., Beebe, S.E., Iglesias, C., and Ortiz-Monasterio, I. 1999. Breeding for micronutrient density in edible portions of staple food crops: conventional approaches. Field Crops Res. 60: $57-80$.

Gregorio, G.B., Senadhira, D., Htut, H., and Graham, R.D. 2000. Breeding for trace mineral density in rice. Food Nutr. Bull. 21: 382-386.

Gu, M.H., Ma, H.T., and Liang, G.H. 1984. Karyotype analysis of seven species in the genus sorghum. J. Hered. 75: 196-202.

Haggag, M.E., Shafey, S.A., and Mousa, M.E. 1993. Variation in salinity tolerance among forage sorghum: sudan hybrids. J. Agric. Sci. 18: 1597-1608.

Hamaker, B.R. and Axtell, D. 1997. Nutritional quality of sorghum. In Proceedings of the International Conference on Genetic Enhancement of Sorghum and Pearl Millet, Lubbock, TX, September 22-27, 1996, pp. 531-538. 
Hamilton, C.M., Frary, A., Lewis, C., and Tanksley, S.D. 1996. Stable transfer of intact molecular weight DNA into plant chromosomes. Proc. Natl. Acad. Sci. U.S.A. 93: 9975-9979.

Hamker, B.R., Kirleis, A.W., Bulter, L.G., Axtell, J.D., and Mertz, E.T. 1987. Improving the in vitro protein digestibility of sorghum with reducing agents. Proc. Natl. Acad. Sci. U.S.A. 84: 626-628.

Hancock, J.D. 2000. Value of sorghum and sorghum Co products in diets for livestock. In Sorghum: Origin, History, Technology and Production, C.W. Smith and R.A. Frederiksen, Eds. John Wiley \& Sons, New York, p. 731.

Hanna, W.W. and Cordona, S.T. 2001. Pennisetums and sorghum in integrated feeding systems in the tropics. In Tropical Forage Plants: Development and Use, A.S. Rios and W.D. Pitman, Eds. CRC Press, Boca Raton, FL, pp. 193-200.

Hanna, W.W. and Schertz, K.F. 1970. Inheritance and trisome linkage of seedling characters in Sorghum bicolor (L.) Moench. Crop Sci. 10: 441-443.

Harlan, J.R. and deWet, J.M.J. 1972. A simplified classification of cultivated sorghum. Crop Sci. 12: 172-176. Harlan, J.R., de Wet, J.M.J., and Price, E.G. 1973. Comparative evolution of cereals. Evolution 27: 311-351. Harris, H.B. 1969. Bird resistance in grain sorghum. Proc. 24th Ann. Corn Sorghum Res. Conf. 24: 113-122. Harris, H.B. and Bums, R.E. 1970. Influence of tannin content on pre-harvest and seed germination in sorghum. Agron J. 62: 835-836.

Hart, G.E., Schertz, K.F., Peng, Y., and Syed, N.Y. 2002. Genetic mapping of Sorghum bicolor (L.) Moench: QTLs that control variation in tillering and other morphological characters. Theor. Appl. Genet. 3: 1232-1242.

Hassanein, A.M. and Azab, A.M. 1990. Test for salt tolerance in grain sorghum. Bull. Fac. Agric. 41: 265-276. Haussmann, B.I.G., Hess, D.E., Reddy, B.V.S., Welz, H.G., and Geiger, H.H. 2000b. Analysis of resistance to Striga hermonthica in diallel crosses of sorghum. Euphytica 116: 33-40.

Haussmann, B.I.G., Hess, D.E., Reddy, B.V.S., Mukuru, N., Seetharama, N., Kayentao, S.Z., Welz, H.G., and Geiger, H.H. 2000c. QTL for Striga resistance in sorghum populations derived from IS 9830 and N 13. In Breeding for Striga Resistance in Cereals, Proceedings of a Workshop, B.I.G. Haussmannn, M.L. Koyama, L. Grivet, H.F. Rattunde, D.E. Hess, Eds., Ibadan, Nigeria, August 18-20, 1999.

Haussmann, B.I.G., Hess, D.E., Sissoko, L., Kayentao, M., Reddy, B.V.S., Welz, H.G., and Geiger, H.H. 2001. Diallel analysis of sooty stripe resistance in sorghum. Euphytica 122: 99-104.

Haussmann, B.I.G., Hess, D.E., Welz, H.G., and Geiger, H.H. 2000a. Improved methodologies for breeding Striga resistant sorghums. Field Crops Res. 66: 195-211.

Haussmann, B.I.G., Mahalakshmi, V., Reddy, B.V.S., Seetharama, N., Hash, C.T., and Geiger, H.H. 2002. QTL mapping of stay-green in two sorghum recombinant inbred populations. Theor. Appl. Genet. 106: 143-148.

Henzell, B., Jordan, D., Tao, Y., Hardy, A., Franzmann, B., Fletcher, D., MacCosker, T., and Bunker, G. 2002. Grain sorghum breeding for resistance to sorghum midge and drought. In Plant Breeding for the 11th Millennium, Proceedings on the 12th Australian Plant Breeding Conference, McComb, J.A., Ed., Perth, Western Australia, September 15-20, pp. 81-86.

Henzell, R.G. 1992. Grain sorghum breeding in Australia: current status and future prospects. In Proceedings of the Second Australian Sorghum Conference, M.A. Foale, R.G. Henzell, and P.N. Vance, Eds., Gatton, Australia, February 4-6, pp. 70-82.

Henzell, R.G., Brengman, R.L., Fletcher, D.S., and McCosker, A.N. 1992a. The release of Q140 and Q141, two-grain sorghum B-lines with a high level of nonsenescence and low levels of sorghum midge resistance. In Proceedings of the Second Australian Sorghum Conference, M.A. Foale, R.G. Henzell, and P.N. Vance, Eds., Gatton, Australia, February 4-6, pp. 360-366.

Henzell, R.G., Brengman, R.L., Fletcher, D.S., and McCosker, A.N. 1992b. Relationship between yield and nonsenescence (stay-green) in some grain sorghum hybrids grown under terminal drought stress. In Proceedings of the Second Australian Sorghum Conference, M.A. Foale, R.G. Henzell, and P.N. Vance, Eds., Gatton, Australia, February 4-6, pp. 355-358.

Henzell, R.G., Dodman, R.L., Done, A.A., Brengman, R.L., and Meyers, R.E. 1984. Lodging, stalk rot and root rot in sorghum in Australia. In Sorghum Root and Stalk Rots: A Critical Review, Proceedings of the Consultative Group Discussion of Research Needs and Strategies for Control of Sorghum Root and Stalk Rot Diseases, L.K. Mughogho, Ed., Bellagio, Italy, November 27-December 2, 1983, pp. 225-236. 
Henzell, R.G., Hammar, G.I., Borrell, A.K., McIntyre, C.L., and Chapman, S.C. 1997. Research on drought resistance in grain sorghum in Australia. Int. Sorghum Millets Newsl. 38: 1-8.

Henzell, R.G. and Hare, B.W. 1996. Sorghum breeding in Australia: public and private endeavors. In Proceedings of the Third Australian Conference, Tamworth, NSW Australia, February 20-22, pp. 159-171.

Hess, D.E. and Ejeta, G. 1992. Inheritance of resistance to Striga in sorghum genotype SRN 39. Plant Breed. 109: 233-241.

Hess, D.E., Ejeta, G., and Butler, L.G. 1992. Selecting sorghum genotypes expressing a quantitative biosynthetic trait that confers resistance to Striga. Photochemistry 31: 493.

Hess, D.E., Obilana, A.B., and Grard, P. 1996. Striga research at ICRISAT. In Advances in Parasitic Plant Research: Proceedings of the Sixth International Parasitic Weed Symposium, Cordoba, Spain, M.T. Moreno, J.I. Cnbero, D. Berner, D. Joel, L.J. Musselman, and C. Parker, Eds., pp. 827-834.

Horst, W.J. 1985. Quick screening of cowpea (Vigna unguiculata) genotypes for aluminium tolerance in an aluminium: treated acid soil. Z. Pflanzenernaehr. Bodenkd. 148: 335-348.

House, L.R. 1985. A Guide to Sorghum Breeding, 2nd ed. International Crops Research Institute for the SemiArid Tropics, Patancheru, India.

House, L.R., Gomez, M., Murty, D.S., Sun, Y., and Verma, B.N. 2000. Development of some agricultural industries in several African and Asian countries. In Sorghum: Origin, History, Technology and Production, C.W. Smith and R.A. Frederiksen, Eds. John Wiley \& Sons, New York, pp. 131-190.

House, L.R., Verma, B.N., Ejeta, G., Rana, B.S., Kapran, I., Obilana, A.B., and Reddy, B.V.S. 1996. Developing countries breeding and potential of hybrid sorghum. In The Proceedings of the Intermational Conference on Genetic Improvement of Sorghum and Pearl Millet, Lubbock, TX, September 22-27, pp. 84-96.

Hulse, J.H., Laing, E.M., and Pearson, O.E. 1980. Sorghum and the Millets: Their Composition and Nutritive Value. Academic Press, New York, pp. 530-592.

Humphreys, M.O. 1994. Variation in carbohydrate and protein content of rye grasses: potential for genetic manipulations, 5-Oct. 1994. In Breeding for Quality: Proceedings of the 19th Eucarpia Fodder Crops Section Meeting, D. Reheul and A. Ghesquiere, Eds., Merelbeke, Belgium, pp. 165-172.

IBPGR. 1976. Proceedings of the Meeting of the Advisory Committee on Sorghum and Millet Germplasm, October 3-7. ICRISAT, Hyderabad, India.

IBPGR/ICRISAT. 1980. Sorghum Descriptors. IBPGR, Rome.

ICRISAT. 1982. Annual Report, 1981. ICRISAT, Patancheru, India.

ICRISAT. 1986. Annual Report, 1985. ICRISAT, Patancheru, India.

ICRISAT. 1987. Annual Report, 1986. ICRISAT, Patancheru, India.

ICRISAT. 1995. Restorers. In ICRISAT Asia Region Annual Report 1992. ICRISAT, Patancheru, India.

ICRISAT. 2000. A Research and Network Strategy for Sustainable Sorghum Production Systems for Latin America, 9th season report, January-June 2000. ICRISAT, Patancheru, India (limited distribution).

ICRISAT. 2002. Archival Report. ICRISAT, Patancheru, India.

ICRISAT, NARS, CIAT. 1997. A Research and Network Strategy for Sustainable Sorghum Production Systems for Latin America, Third Report. ICRISAT, Patancheru, India.

Igartua, E. 1995. Choice of selection environment for improving crop yields in saline areas. TAG 91: 1016.

Igartua, E. and Gracia, M.P. 1998. Divergent selection for salinity tolerance at the germination-emergence stage in grain sorghum. Maydica 43: 161.

Igartua, E., Gracia, M.P., and Lasa, J.M. 1994. Characterization and genetic control of germination emergence responses of grain sorghum to salinity. Euphytica 76: 185.

IPGRI. 1993. Diversity for Development. IPGRI, Rome.

Jayanthi, P.D.K. 1997. Genetics of Shoot Fly Resistance in Sorghum Hybrids of Cytoplasmic Male Sterile Lines. Ph.D. thesis, Acharya N.G. Ranga Agricultural University, Rajendranagar, Hyderabad, India.

Jordan, W.R., Dugas, W.A., and Stenhouse, P.J. 1983. Strategies for crop improvement for drought prone regions. Agric. Water Manage. 7: 281-299.

Jordan, W.R. and Monk, R.L. 1980. Enhancement of drought resistance of sorghum: progress and limitations. In Proceedings of the 35th Annual Corn and Sorghum Research Conference. Annual Seed Trade Association, Chicago, pp. 185-204.

Jordan, W.R. and Sullivan, C.Y. 1982. Reaction and resistance of grain sorghum to heat and drought. In Sorghum in the Eighties. ICRISAT, Hyderabad, India, pp. 131-142.

Jorgenson, L.R. 1931. Brown-midrib in maize and its linkage relations. J. Am. Soc. Agron. 23: 549-557. 
Jotwani, M.G. 1976. Host plant resistance with special reference to sorghum. Proc. Natl. Acad. Sci. U.S.A. 46: 42.

Kadam, D.E., Patil, F.B., Bhor, T.J., and Harer, P.N. 2001. Genetic diversity studies in sweet sorghum. J. Maharshtra Agric. Univ. 26: 140-143.

Kalton, R.R. 1988. Overview of forage sorghums. Proc. Ann. Corn Sorghum Res. Conf. 43: 1-12.

Kebede, H., Subudhi, P.K., Rosenow, D.T., and Nguyen, H.T. 2001. Quantitative trait influencing drought tolerance in grain sorghum (Sorghum bicolor L. Moench). Theor: Appl. Genet. 103: 266-276.

Kimber, C.T. 2000. Origins of domesticated sorghum and its early diffusion to India and China. In Sorghum: Origin, History, Technology and Production, C.W. Smith and R.A. Frederiksen, Eds. John Wiley \& Sons, New York, 2000, pp. 3-98.

Kleih, U., Bala Ravi, S., and Rao, B.D., 2000. Industrial utilization of sorghum in India. In Sorghum Utilization and the Livelihoods of the Poor in India, A.J. Hall and B. Yoganand, Eds. ICRISAT, Patancheru, India, pp. 73-78.

Klein, R.R., Rodriguez-Herrera, R., Schlueter, J.A., Klein, P.E., Yu, Z.H., and Rooney, W.L. 2001 . Identification of genomic regions that affect grain mold incidence and other traits of agronomic importance in sorghum. Theor: Appl Genet. 102: 307-319.

Kling, J., Fajemisin, J.M., Badu-Apraku, B., Diallo, A., Menkir, A., and Melake-Berhan, A. 2000. Striga resistance breeding in maize. In Breeding for Striga Resistance in Cereals, Proceedings of a Workshop, B.I.G. Haussmann, D.E. Hess, M.L. Koyama, L. Grivet, H.F.M. Rattunde, and H.H. Geiger, Eds., Ibadan, Nigeria, August 18-20, 1999, pp. 103-118.

Klopfenstein, C.F. and Hoseney, R.C. 1995. Nutritional Properties of sorghum and the millets. In Sorghum and Millets: Chemistry and Technology, D.A.V. Dendy, Ed. American Association of Cereal Chemists, St. Paul, MN, pp. 125-168.

Kogan, M. and Ortman, E.E. 1978. Antixenosis: a new term proposed to replace painters 'non-preference' modality of resistance. Bull. Entomol. Soc. Am. 24: 175-176.

Kramer, P.J. 1980. Drought stress and the origin of adaptations. In Adaptation of Plants to Water and High Temperature Stress, N.C. Tumer and P.J. Karmer, Eds. Wiley Interscience, New York, pp. 7-20.

Krieg, D.R. 1993. Stress tolerance mechanisms in above ground organs. In Proceedings of a Workshop on Adaptation of Plants to Soil Stresses, Lincoln, NE, August 1-4, 1993, pp. 65-79.

Lazarides, M., Hacker, J.B., and Andrew, M.H. 1991. Taxonomy, cytology and ecology of indigenous Australian sorghums (Sorghum Moench: Andropogoneae: poaceae). Aust. Syst. Bot. 4: 591-635.

Levitt, J. 1992. Responses of Plants to Environmental Stresses. Academic Press, New York.

Lin, Y.R., Schertz, K.F., and Paterson, A.H. 1995. Comparative analysis of QTLs affecting plant height and maturity across the Poaceae, in reference to an interspecific sorghum population. Genetics 140: $391-411$.

Lu, Q. 1994. RFLP techniques and sorghum breeding. In Use of Molecular Markers in Sorghum and Pearl Millet Breeding for Developing Countries, Proceedings of an ODA Plant Sciences Research Programme Conference, J.R. Witcombe and R.R. Duncan, Eds., Norwich, U.K., March 29-April 1, 1993, pp. 15-16.

Ludlow, M.M. 1993. Physiological mechanisms of drought resistance. In Proceedings of Symposium on Application and Prospects of Biotechnology, Mabry, T.J., Nguyen, H.T., and Dixon, R.A., Eds., Lubbock, TX, November 5-7, 1992, pp. 11-34.

Luo, Y.W., Yen, X.C., Zhang, G.Y., and Liang, G.H. 1992. Agronomic traits and chromosomal behavior of autotetraploid sorghums. Plant Breed. 109: 46-53.

Maas, E.V. and Hoffman, G.S. 1977. Crop salt tolerance: current assessment. J. Irrig. Drainage Div. ASCE 103: 115-134.

Maciel, G.A., de Andrade Lima, M.M., Duncan, R.R., de Franca, J.G.E., and Tabosa, J.N. 1994a. Combining ability of aluminium tolerance in grain sorghum lines. Int. Sorghum Millets Newsl. 35: 73-74.

Maciel, G.A., de Andrade Lima, M.M., Santos, J.P.O., Tabosa, J.N., and de Franca, J.G.E. 1994b. Screening new grain sorghum introductions for aluminium tolerance. Int. Sorghum Millets Newsl. 35: 117-118.

Maciel, G.A., Tavares, J.A., de Andrade Lima, M.M., de Tabosa, J.N., and Neto, C.A. 1992. Preliminary evaluation of grain sorghum for aluminium tolerance in northeastern Brazil. Sorghum Newsl. 33: 57.

Maclean, W.C., Lopez de Romana, G., and Graham, G.G. 1983. The effects of decortication and extrusion on the digestibility of sorghum by preschool children. J. Nutr: 113: 2171. 
Magill, C.W., Boora, K., Sunitha Kumari, R., Osorio, J., Oh, B.J., Gowdsa, B., Cui, Y., and Frederiksen, R. 1997. Tagging sorghum genes for disease resistance: expectations and reality. In International Conference on Genetic Improvement of Sorghum and Pearl Millet, Rosenow et al., Eds. Lubbock, TX, September 22-27, 1996, pp. 316-325.

Magnavaca, R., Lakins, B.A., Schaffert, R.C., and Lopes, M.A. 1993. Improving protein quality of maize and sorghum. In International Crop Science I, D.R. Buxton, R.A. Shibles, R.A. Forsberg, B.L. Blad, K.H. Asay, G.H. Paulsen, and R.F. Wilson, Eds. Crop Science Society of America, Madison, WI, pp. 649-653.

Mahalakshmi, V. and Bidinger, F.R. 2002. Evaluation of stay-green sorghum germplasm lines at ICRISAT. Crop Sci. 42: 965-974.

Mahalanobi, P.C. 1936. On the generalised distance in statistics. Proc. Natl. Inst. Sci. India B2: 49-55.

Maiti, R.K., de la Rosa, M. and Alicia, L. 1994. Evaluation of several sorghum genotypes for salinity tolerance. Int. Sorghum Millets Newsl. 35: 121.

Major, D.J. 1980. Photoperiod response characteristics controlling flowering of nine crop species. Can. J. Plant Sci. 60: 777-784.

Mali, P.C. and Gupta, Y.P. 1974. Chemical composition and protein quality of improved Indian varieties of Sorghum Vulgare pers. Indian J. Nutr. Diet. 11: 289-295.

Mallick, A.S., Gupta, M.P., and Pandey, A.K. 1988. Combining ability of some quality traits in grain sorghum [Sorghum bicolor (L) Moench]. Indian J. Genet. 48: 63-68.

Mann, J.A., Kimber, C.T., and Miller, F.R. 1983. The origin and early cultivation of sorghums in Africa. Tex. Agric. Exp. Stn. Bull. 1454.

Marschner, H. 1991. Mechanisms of adaptation of plants to acid soils. Plant Soil 134: 1-20.

Maunder, A.B. 1972. Objectives and approaches to grain and forage sorghum improvement in the Americas. In Sorghum in the Seventies, N.G.P. Rao and L.R. House, Eds. Oxford and IBH Publishing Co., New Delhi, pp. 60-100.

Maurya, D.M., Bottrall, D.M., and Farrington, J. 1988. Improved livelihood, genetic diversity and farmers' participation: strategy for rice breeding in rain fed areas of India. Exp. Agric. 24: 311-320.

Mbwaga, A.M. and Obilana, A.J. 1994. Distribution and host specificity of Striga asiatica and Striga hermonthica in cereals in Tanzania. Int. J. Pest Manage. 39: 449-451.

McCollough, R.L., Drake, C.L., Roth, G.M., Brent, B.E., Riley, R.G., and Schalles, R.R. 1972. Several reports on the nutritive value of hybrid sorghum grains. Kan. Agric. Exp. Stn. Bull. 577: 15-17.

McMillian, W.W., Wiseman, B.R., Burns, R.E., Harris, H.B., and Greene, G.L. 1972. Bird resistance in diverse germplasm of sorghum. Agron J. 64: 821-822.

Menkir, A., Goldsbrough, P., and Ejeta, G. 1997. RAPD based assessment of genetic diversity in cultivated races of sorghum. Crop Sci. 37: 564-569.

Miller, F., Muller, N., Monk, R., Murty, D.S., and Obilana, A.B. 1997. Breeding photoperiod insensitive sorghums for adaptation and yield. In International Conference on Genetic Improvement of Sorghum and Pearl Millet, Lubbock, TX, September 22-27, 1996, pp. 59-65.

Miller, F.R. 1980. The breeding of sorghum. Tex. Agric. Exp. Stn. 1451: 128-136.

Miller, F.R. 1982. Genetic and environmental response characteristics of sorghum. In Sorghum in the Eighties. ICRISAT, Patancheru, India, pp. 393-402.

Miller, F.R. 1992. Improvements in sorghum during the last 25 years. In Proceedings of the Second Australian Sorghum Conference, M.A. Foale, R.G. Henzell, and P.N. Vance, Eds., Gatton, Australia, February 4-6, pp.

Miller, F.R., Bames, D.K., and Cruzado, H.J. 1968. Effect of tropical photoperiods on the growth of Sorghum bicolor (L.) Moench, when grown in 12 monthly plantings. Crop Sci. 8: 499-502.

Miller, F.R. and Kebede, Y. 1984. Genetic contributions to yield gains in sorghum, 1950 to 1980. In Genetic Contributions to Yield Gains of Five Major Crop Plants, CSSA Special Publication 7, W.R. Fehr, Ed. CSSA, ASA, Madison, WI, pp. 1-14.

Mohan, D.P. 1975. Chemically Induced'High Lysine Mutant in Sorghum bicolor (L.) Moench. Ph.D. thesis, Purdue University, Lafayette, IN.

Mohanty, B.D., Maiti, S., and Ghosh, P.D. 1986. Establishment of karyotype in Sorghum bicolor through somatic metaphase and pachytene analysis. In Perspectives in Cytology and Genetics, Proceedings of the Fifth All India Congress of Cytology and Genetics, Vol. 5, G.K. Manna and U. Sinha, Eds., Bhubaneshwar, India, October 7-10, 1984, pp. 559-563. 
Monasterio, I. and Graham, R.D. 2000. Breeding for trace minerals in wheat. Food Nutr. Bull. 21: 392.

Montemurro, F., Rigoldi, M.P., Sunseri, F., and Vanadia, S. 1994. Early screening methodologies for selecting salt stress tolerant sweet sorghum [Sorghum bicolor (L.) Moench]. Rivista Agron. 28: 179-183.

Mukuru, S.Z. 1992. Breeding for grain mold resistance. In Sorghum and Millet Diseases, A Second World Review, W.A.J. de Milliano, R.A. Frederiksen, and G.D. Bengston, Eds. ICRISAT, Patanchen, India, pp. 273-285.

Murthy, U.R. 1986. Apomixis: achievements, problems and future prospects. In Advanced Methods in Plant Breeding. Oxford and IBH, New Delhi.

Murthy, U.R., Schertz, K.F., and Bashaw, E.C. 1979. Apomictic and sexual reproduction in sorghum. Indian J. Genet. Plant Breed. 39: 271-278.

Murty, B.R. and Arunachalam, V. 1967. Factor analysis of genetic diversity in the genus sorghum. Indian J. Genet. 27: 123-135.

Murty, B.R., Arunachalam, V., and Saxena, M.B.L. 1967. Cataloguing and classifying a world collection of genetic stocks of sorghum. Indian J. Genet. 27A: 1-312.

Murty, D.S. and Kumar, K.A. 1995. Traditional uses of sorghum and millets. In Sorghum and Millets: Chemistry and Technology, D.A.V. Dendy, Ed. American Association of Cereal Chemists, St. Paul, MN, pp. 185-221.

Murty, U.R. and Rao, N.G.P. 1997. Sorghum. In Genetics, Cytogenetics and Breeding of Crop Plants, Vol. 2, Cereal and Commercial Craps, P.N. Bahl, P.M. Salimath, and A.K. Mandal, Eds. Oxford \& IBH Publishing Co. Pvt. Ltd., New Delhi, pp. 197-239.

Murty, U.R. 1991. National Programme on Sorghum Research in India. Paper presented at the consultative meeting to consider establishment of Regional Sorghum Research Network for Asia, Patancheru, India, September 16-19.

Murty, U.R. 1992. ICAR_ICRISAT Collaborative Research Projects: Sorghum Progress Report. National Research Center on Sorghum 27.

Murty, V.R. and Rao, N.G.P. 1977. Sorghum. In Genetics, Cytogenetic and Breeding of Crop Plants, Vol. 2, P.N. Bahl, P.M. Salimath, and A.K. Mandal, Eds. Oxford and IBH Publishing Co. Pvt. Ltd, New Delhi, pp. 197-239.

Myer, R.O. and Gorbet, D.W. 1985. Waxy vs. normal grain sorghums with varying tannin contents in diets for young pigs. Anim. Feed Sci. Technol. Amsterdam 12(3): 179-186.

Nanda, G.S. and Rao, N.G.P. 1974. Gene action for vitamins in grain sorghum. Crop Improve. 1: 53-60.

Nanda, G.S. and Rao, N.G.P. 1975a. Gene action for content of amino acid in grain sorghum. Indian J. Genet. 35: 395-398.

Nanda, G.S. and Rao, N.G.P. 1975b. Genetic analysis of some exotic $\infty$ Indian crosses in sorghum. IX. Nutritional quality and its association with grain yield. Indian J. Genet. 35: 131-135.

Narkhede, B.N., Akade, J.H., and Awari, V.R. 2001. Genetic diversity in rabi sorghum local types [Sorghum bicolor (L.) Monech]. J. Maharashtra Agric. Univ. 25: 245-248.

Nayeem, K.A. and Bapat, D.R. 1984. Combining ability in grain sorghum. Indian J. Genet. 44: 353-357.

Nguyen, H.T., Xu, W., Rosenow, D.T., Mullet, J.E., and McIntyre, L. 1997. Use of biotechnology in sorghum drought resistance breeding conference on genetic improvement of sorghum and pearl millet. In Intermational Conference on Genetic Improvement of Sorghum and Pearl Millet, Lubbock, TX, September 22-27, 1996, pp. 412-424.

Noland, P.R., Campbell, D.R., Sharp, R.N., and Johnson, Z.B. 1977. Influence of pericarp and endosperm color and type on digestibility of grain sorghum by pigs. Anim. Feed Sci. Technol. 2: 219-224.

Nwanze, K.F., Seetharama, N., Sharma, H.C., and Stenhouse, J.W. 1995. Biotechnology in pest management: improving resistance to sorghum to insect pests. Afr. Crop Sci. J. 3: 209-215.

Obilana, A.B. 1983. Striga studies and control in Nigeria. In Proceedings of the Second International Workshop on Striga, K.V. Ramaiah and M.J. Vasudeva Rao, Eds., Quagadougou, Upper Volta, Burkina Faso, October 5-8, 1981, pp. 87-98.

Obilana, A.B., de Milliano, W.A.J., and Mbwaga, A.M. 1991. Striga research in sorghum and millets in southern Africa: status and host plant resistance. In Proceedings of the Fifth International Symposium of Parasitic Weeds, J.K. Ransom, L.J. Musselman, A.D. Worsham, and C. Parker, Eds., Nairobi, Kenya, June 24-30, pp. 435-441. 
Oh, B.J., Gowda, P.S.B., Xu, G.W., Frederiksen, R.A., and Magill, C.W. 1993. Tagging Acremonium wilt, downy mildew and head smut resistance genes in sorghum using RFLP and RAPD markers. Sorghum Newsl. 34: 34.

Oria, M.P., Hamaker, B.R., and Axtell, J.D. 2000. A highly digestible sorghum cultivar exhibits a unique folded structure of endosperm protein bodies. Proc. Natl. Acad. Sci. U.S.A. 97: 5065-5070.

Owen, F.G. and Moline, W.J. 1970. Sorghum for forage. In Sorghum Production and Utilization, J.S. Wall and W.M. Ross, Eds. AVI Publication Co., Westport, CT, pp. 382-415.

Parker, C., Hitchock, A.M., and Ramaiah, K.V. 1977. The germination of Striga species by crop root exudates, techniques for selecting resistant crop cultivars. In Proceedings of the 6th Asian-Pacific Weed Science Society Conference, Indiana, Indonesia, 1: 67.

Paterson, A.H. 1994. Status of genome mapping in sorghum and prospects for marker-associated selection in sorghum improvement. Int. Sorghum Millet Newsl. 35: 89-91.

Paterson, A.H., Schertz, K.F., Lin, Y., and Li, Z. 1998. Case history in plant domestication: sorghum an example of cereal evolution. In Molecular Dissection of Complex Traits, A.H. Paterson, Ed. CRC Press, Boca Raton, FL.

Peacock, J.M. and Sivakumar, M.V.K. 1987. An environmental physiologist's approach to screening for drought resistance to sub-Saharan Africa. In Food Grain Production in Semi-Arid Africa, Proceedings of International Drought Symposium, Nairobi, Kenya, May 19-23, 1986, pp. 101-120.

Pearson, K. 1901. On thelinesand planes of closest fit to a system of points in a space. Philos.Mag. 2: 557-572.

Pederson, J.F. 1997. Breeding sorghum and pearl millet for forage and fuel. In International Conference on Genetic Improvement of Sorghum and Pearl Millet, Lubbock, TX, September 22-27, 1996, pp. 539-548.

Pedersen, J.F. and Fritz, J.O. 2000. Forages and fodder. In Sorghum: Origin, History, Technology and Production, W.C. Smith and R.A. Frederiksen, Eds. John Wiley \& Sons, New York, pp. 797-810.

Peng, J., Lill, H., Li, J., and Tan, Z. 1994. Screening Chinese sorghum cultivars for tolerance to salinity. Sorghum Millets Newsl. 35: 124.

Peng, Y., Schertz, K.F., Cartinhour, S., and Hart, G.E. 1999. Comparative genome mapping of Sorghum bicolor (L.) Moench using an RFLP map constructed in a population of recombinant inbred lines. Plant Breed. 118: 225-235.

Pereira, M.G., Ahnert, D., Lee, M., and Klier, K. 1995. Genetic mapping of quantitative trait loci for panicle characteristics and seed weight in sorghum. Rev. Bras. Genet. 18: 249-257.

Pereira, M.G., Lee, M., Bramel-Cox, P., Wordman, W., Doebley, J., and Whitkus, R. 1994. Construction of an RFLP map in sorghum and comparative mapping in maize. Genome 37: 236-243.

Peterson, G.C., Reddy, B.V.S., Youm, O., Teetes, G.I., and Lambright, L. 1997. Breeding for resistance for foliar- and stem-feeding insects of sorghum and pearl millet. In International Conference on Genetic Improvement of Sorghum and Pearl Millet, Lubbock, TX, September 22-27, 1996, pp. 281-302.

Platt, B.S. 1962. Tables of Representative Values of Food Commonly Used in Tropical Countries, Medical Research Council Special Report Series 302 (revised edition of SRS 253). H.M. Stationery Office, London.

Porter, K.S., Axtell, J.D., Lechtenberg, V.L., and Colenbrander, V.F. 1978. Phenotype, fiber composition and in vitro dry matter disappearance of chemically induced brown-midrib (bmr) mutants of sorghum. Crop Sci. 18: 205-208.

Prasada Rao, K.E., Gopal Reddy, V., and Stenhouse, J.W. 1995. Sorghum genetic resources at ICRISAT Asia Center. Int. Sorghum Millets Newsl. 36: 15-19.

Prasada Rao, K.E., Mengesha, M.H., and Reddy, V.G. 1989. International use of sorghum germplasm collection. In The Use of Plant Genetic Resources, A.H.D. Brown, O.H. Frankel, D.R. Marshall, and J.T. Williams, Eds. Cambridge University Press, Cambridge, U.K., pp. 150-167.

Prasada Rao, K.E. and Ramanatha Rao, V. 1995. Use of characterization data in developing a core collection of sorghum. In Core Collection of Plant Genetic Resources, T. Hodgkin, H.D. Brown, J.L. Hinthum, and E.A.V Morales, Eds. John Wiley \& Sons, Chichester, U.K., pp. 109-111.

Pushpamma, P., Ratnakumari, H., and Geervani, P. 1970. Nutritional quality of sorghum and legume based food mixture for infants and preschool children II. Nutr. Rep. Int. 19: 643-649.

Qingshan, L. and Dahlberg, J.A. 2001. Chinese sorghum genetic resources. Econ. Bot. 55: 401-425.

Quinby, J.R. 1973. The genetic control of flowering and growth in sorghum. In Advances in Agronomy, N. Brady, Ed. Academic Press, New York, pp. 125-162. 
Quinby, J.R. 1974. Sorghum Improvement and the Genetics of Growth. Texas A\&M University Press College Station, Lubbock, Texas.

Quinby, J.R., Hesketh, J.D., and Voigt, R.L. 1973. Influence of temperature and photoperiod on floral initiation and leaf number in sorghum. Crop Sci. 13: 243-246.

Quinby, J.R. and Karper, R.E. 1946. Heterosis in sorghum resulting from the heterozygous condition of a single gene that affects duration of growth. Am. J. Bot. 33: 716-721.

Quinby, J.R. and Karper, R.E. 1954. Inheritance of height in sorghum. Agron J. 46: 212-216.

Rai, M. 2002. Genetic resources and intellectual property rights in agriculture perspective. Indian J. Pulses Res. 15: 1-18.

Rai, K.N., Murty, D.S., Andrews, D.J., and Bramel-Cox, P.J. 1999. Genetic enhancement of pearl millet and sorghum for the semi-arid tropics of Asia and Africa. Genome 42: 617-628.

Ramaiah, K.V. 1987. Breeding cereal grains for resistance to witch weed. In Parasitic Weeds in Agriculture, Vol. 1, L.J. Musselman, Ed. CRC Press, Boca Raton, FL, pp. 227-242.

Rami, J.F., Dufour, P., Trouche, G., Fliedel, G., Mestress, C., Davrieux, F., Blanchard, P., and Hamon, P. 1998. Quantitative trait loci for grain quality, productivity, morphological and agronomical traits in sorghum (Sorghum bicolor L. Moench). Theor: Appl. Genet. 97: 605-616.

Rana, B.S., Jotwani, M.G., and Rao, N.G.P. 1980. Inheritance of host plant resistance to sorghum shoot fly. In Insect Science and Its Application, IC1PE, Nairobi, Kenya, May 4-8.

Rana, B.S., Kaul, S.L., Chari, A., Reddy, B.V.S., WitCombe, J.R., and Virk, D.S. 1998. Farmer's participatory varietal selection for improving rabi sorghum productivity in India. In Participatory Plant Improvement: Proceedings of the MSSRF-ICRISAT Workshop 1998, Chennai, India, pp. 31-37.

Rana, B.S. and Murty, B. R. 1971. Genetic analysis of resistance to stem borer in sorghum. Indian J. Genet. 31: 521-529.

Rana, B.S. and Murty, B.R. 1975. Heterosis and components of genetic variation for protein and lysine content in some grain sorghums. Theor: Appl. Genet. 45: 225-230.

Rao, N.G.P. 1972. Sorghum breeding in India: recent developments. In Sorghum in the Seventies, N.G.P. Rao and L.R. House, Eds. Oxford and IBH Publishing Co., New Delhi, pp. 101-142.

Rao, V.J.M., Deosthale, Y.G., Rana, B.S., Vidyasagar Rao, K., and Rao, N.G.P. 1983a. Genetic analysis of some exotic $\times$ Indian crosses in sorghum. XXXI. Nutritional quality in grain sorghum: variability for protein, lysine and leucine. Indian J. Genet. 43: 380-382.

Rao, V.J.M., Deosthale, Y.G., Rana, B.S., Vidyasagar Rao, K., and Rao, N.G.P. 1983b. Genetic analysis of some exotic $\times$ Indian crosses in grain sorghum. XXXII. Nutritional quality in grain sorghum: behaviour of crosses involving between high lysine sorghum and agronomically superior types. Indian J. Genet. 43: $395-403$.

Rao, V.J.M., Mehta, S.L., and Rao, N.G.P. 1984a. Breeding sorghums for high protein content and quality. Indian J. Genet. 44: 305-313.

Rao, N.G.P. and Murthy, U.R. 1972. Further studies on obligate apomixis in grain sorghum, Sorghum bicolor (L.) Moench. Indian J. Genet. 32: 379-383.

Rao, N.G.P. and Rana, B.S. 1982. Selection in temperate and tropical crosses of sorghum. In Sorghum in the Eighties, Proceedings of International Symposium on Sorghum, 2-7 Nov. 1981, ICRISAT, Patancheru, India, pp. 403-420.

Rao, V.J.M., Rana, B.S., Reddy, B.B., and Rao, N.G.P. 1984b. Genetic upgrading of protein quality in sorghum. In Nutritional and Processing Quality of Sorghum, D.K. Salunkhe, J.K. Chavan, and S.J. Jadhav, Eds. Oxford and IBH Publishing Co., New Delhi, pp. 67-90.

Ramadass, A., Chantereau, J., Coulibaly, M.F., and Cilas, C. 2002. Inheritance of resistance to the paniclefeeding bug (Eurystylus oldi) and the sorghum midge (Stenodiplosis sorghicola) in sorghum. Euphytica 123: 131-138.

Rattunde, E.W. 2002. Participatory breeding with sorghum in Mali: statistical and analytical aspects. In Quantitative Analysis of Data from Participatory Methods in Plant Breeding, M.R. Bellon and J. Reeves, Eds. CIMMYT, Mexico, D.F., pp. 140-141.

Rattunde, H.F.W., Obilana, A.B., Haussmann, B.I.G., Reddy, B.V.S., and Hess, D.E. 2000. In Breeding for Striga Resistance in Cereals, Proceedings of a Workshop, B.I.G. Haussmann, D.E. Hess, M.L. Koyama, L. Grivet, H.F.W. Rattunde, and H.H. Geiger, Eds., Ibadan, Nigeria, August 18-20, p. 85.

Raynal-Roques, A. 1987. The genus Striga (Scrophulariaceae) in western and central Africa: a survey. In Parasitic Flowering Plants, H. Weber and W. Forstreuter, Eds. Marburg, Germany, p. 675. 
Reddy, B.V.S. 1985. Relatorio final de consultoria. IICA/EMBRAPA/IPA, p. 83.

Reddy, B.V.S. 1986. Genetic improvement for drought resistance in sorghum: a plant breeder's viewpoint. In Genetic Improvement of Drought Resistance, Proceedings of a Discussion Series of the Drought Research Seminar Forums, ICRISAT, Patancheru, India, pp. 28-32.

Reddy, B.V.S. 1993. Varietal improvement: breeding Striga resistant seed parents. In Cereal Program, ICRISAT, Annual Report 1992. ICRISAT, Patancheru, India.

Reddy, B.V.S., Bandyopadhyay, R., Ramaiah, B., and Ortiz, R. 2000. Breeding grain mold resistant sorghum cultivars. In Technical and Institutional Options for Sorghum Grain Mold Management: Proceedings of an International Consultation, A. Chandrashekar, R. Bandyopadhyay, and A.J. Hall, Eds., May 18-19. ICRISAT, Patancheru, India, pp. 195-224.

Reddy, B.V.S., Hall, A.J., and Rai, K.N. 2001. The long road to partnership: private support of public research on sorghum and pearl millet. In Sharing Perspectives on Public-Private Sector Interaction: Proceedings of a Workshop, A.J. Hall, B. Yoganand, V. Rasheed Sulaiman, and N.G. Clark, Eds., April 10. ICRISAT, Patancheru, India, pp. 27-34.

Reddy, B.V.S., Hash, C.T., Stenhouse, J.W., Nigam, S.N., Singh, L., and Van Rheenen, H.A. 1994. Crop Improvement for Livestock Crop Residue Feed at ICRISAT Asia Center. pp. 85-92.

Reddy, B.V.S., Mughogho, L.K., and Jambunathan, R. 1992. Breeding grain mold resistance seed parents and hybrids. In Cereals Program, Annual Report, 1991. ICRISAT, Patancheru, pp. 28-29.

Reddy, B.V.S. and Prasada Rao, K.E. 1993. Varietal Improvement: Genetic Diversification in Cereals Program, ICRISAT Annual Report 1992. ICRISAT, Patancheru, pp. 48-51.

Reddy, B.V.S., Prakasha Rao, P., Deb, U.K., Stenhouse, J.W., Ramaiah, B., and Ortiz., R. 2004a. Global sorghum genetic enhancement processes at ICRISAT. In Sorghum Genetic Enhancement: Research Process, Dissemination and Impacts, M.C.S. Bantilan, U.K. Deb, C.L.L. Gowda, B.V.S. Reddy, A.B. Obilana, and R.E. Evenson, Eds. ICRISAT, Patancheru, pp. 65-102.

Reddy, B.V.S. and Rangel, A.F. 2000. Genotype (G) $\times$ environment (E) interactions in sorghum in acid-soils of the oriental Llanos of Colombia. In A Research and Network Strategy for Sustainable Sorghum and Pearl Millet Production Systems for Latin America: Proceedings of the Workshop, Villavicencio, Meta, Colombia, November 24-26, 1998. ICRISAT, Patancheru, pp. 46-51.

Reddy, B.V.S., Rangel, A.F., and Iglesaias, C. 1998. Latin American Sorghum Project: some results. In Proceedings of the First International Symposium on Sorghum, Rio Bravo, Tamaulipas, Mexico, May 27-30, pp. 70-79.

Reddy, B.V.S., Rangel, A.F., Ramaiah, B., and Ortiz, R. 2004b. A research and network strategy for sustainable sorghum production systems for Latin America. In Sorghum Genetic Enhancement: Research Process, Dissemination and Impacts, M.C.S. Bantilan, U.K. Deb, C.L.L. Gowda, B.V.S. Reddy, A.B. Obilana, and R.E. Evenson, Eds. ICRISAT, Patancheru, pp. 139-148.

Reddy, B.V.S. and Seetharama, N. 2001. Sorghum improvement: a case study for integrating traditional breeding and transgenic research methods. In Sorghum: Tissue Culture, Transformation and Genetic Engineering, N. Seetharama and I.D. Godwin, Eds. ICRISAT and Oxford Publishers, India.

Reddy, B.V.S. and Stenhouse, J.W. 1994a. Sorghum improvement for semi-arid tropics region: past current and future research thrusts in Asia. PKV Res. J. 18: 155-169.

Reddy, B.V.S. and Stenhouse, J.W. 1994b. Improving Postrainy Season Sorghum, a Case for Landrace Hybrids Approach. Invited paper presented at All India Coordinated Sorghum Improvement Project (AICSIP), Pantnagar, India, April 18-20.

Reddy, C.S., Schertz, K.F., and Bashaw, E.C. 1980. Apomictic frequency in sorghum R 473. Euphytica 29: 223-226.

Reddy, N.P.E. and Jacobs, M. 2000. Polymorphism among kakinins and esterases in normal and lysine-rich cultivars of Sorghum. Indian J. Genet. 60: 159-170.

Reich, V.H. and Atkins, R.E. 1971. Variation and interrelationship of protein, oil content and seed weight in grain sorghum. Iowa State J. Sci. 46: 13-22.

Richards, R.A. and Dennett, C.W. 1980. Variation in salt concentration in a wheat field. Soil Water 44: 8-9.

Richards, R.A., Dennett, C.W., Qualset, C.O., Epstein, E., Norlyn, J.D., and Winslow, M.D. 1987. Variation in yield of grain and biomass in wheat, barley and triticale in a salt-affected field. Field Crops Res. 15: $277-287$. 
Riches, C.R., De Milliano, W.A.J., Obilana, A.T., and House, L.R. 1987. Witch weeds (Striga spp.) of sorghum and pearl millet. In Third Regional SADCC/ICRISAT Sorghum and Millet Improvement Project Workshop, Lusaka, Zambia, September 20-25, 1986.

Richter, C., Heiligtag, B., Gertling, M., and Abdullahzadeh, A. 1995. Salt tolerance of different varieties of Sorghum bicolor and Vicia faba. Tropenlandwirt 96: 141-152.

Rodriguez-Herrera, R., Waniska, R.D., and Rooney, W.L. 1999. Antifungal proteins and grain mold resistance in sorghum with a non-pigmented testa. J. Agric. Food Chem. 47: 4802-4806.

Rooney, W.L. 2000. Genetics and cytogenetics. In Sorghum, Origin, History, Technology and Production, Wiley Series in Crop Science, C.W. Smith and R.A. Frederiksen, Eds. John Wiley \& Sons, New York, pp. 261-307.

Rooney, L.W., Hamker, B.R., and Botorou, Q. 2003. Grains in West Africa: Processing and Product Marketing through Value Added Supply Chain Management. Concept note paper presented in the expert meeting on alternative uses of sorghum and pearl millet in Asia, Patancheru, India, July $1-4$.

Rooney, W.L. and Klein, R.R. 2000. Potential of marker-assisted selection for improving grain mold resistance in sorghum. In Technical and Institutional Options for Sorghum Grain Mold Management: Proceedings of an International Consultation, A. Chandrashekar, R. Bandyopadhyay, and A.J. Hall, Eds., Patancheru, India, May 18-19, pp. 183-194.

Rooney, L.W. and Plugfelder, R.L. 1986. Factors affecting starch digestibility with special emphasis on sorghum and com. J. Anim. Sci. 63: 1607.

Rooney, W.L. and Smith, C.W. 2000. Techniques for developing new cultivars. In Sorghum, Origin, History, Technology and Production, Wiley Series in Crop Science, C.W. Smith and R.A. Frederiksen, Eds. John Wiley \& Sons, New York, pp. 329-347.

Rosenow, D.T. 1992. Using germplasm from the world collection in breeding for disease resistance. In Sorghum and Millet Diseases: A Second World Review, W.A.J. de Milliano, R.A. Frederiksen, and G.D. Bengston, Eds. ICRISAT, Patancheru, India, pp. 319-324.

Rosenow, D.T. 1994. Evaluation of drought and disease resistance in sorghum for use in molecular markerassisted selection. In Use of Molecular Markers in Sorghum and Pearl Millet Breeding for Developing Countries, Proceedings of an ODA Plant Sciences Research Programs Conference, J.R. Witcombe and R.R. Duncan, Eds., Norwich, U.K., March 29-April 1, 1993, pp. 27-31.

Rosenow, D.T. and Clark, L.E. 1995. Drought and lodging resistance for a quality sorghum crop. In Proceedings of the Fiftieth Annual Corn and Sorghum Industry Research Conference, Chicago, December 6-7, pp. 82-97.

Rosenow, D.T. and Dalhberg, J.A. 2000. Collection, conversion and utilization of sorghum. In Sorghum, Origin, History, Technology and Production, Wiley Series in Crop Science, C.W. Smith and R.A. Frederiksen, Eds. John Wiley \& Sons, New York, pp. 309-328.

Rosenow D.T., Dahlberg, J.A., Paterson, G.C., Clark, L.E., Sotomayor-R'os, A., Miller, F.R., Hamburger, A.J., Madera-Torres, P., Quiles-Belen, A., and Woodfin, C.A. 1995. Release of 50 converted sorghum lines and 253 partially converted sorghum bulks. Int. Sorghum Millets Newsl. 36: 19-31.

Rosenow, D.T., Ejeta, G., Clark, L.E., Grilbert, M.L., Henzell, R.G., Borrell, A.K., and Muchow, R.C. 1997. Breeding for pre-and post-flowering drought stress resistance in sorghum. In International Conference on Genetic Improvement of Sorghum and Pearl Millet, Lubbock, TX, September 22-27, 1996, pp. 400-411.

Rosenow, D.T., Quisenberry, J.E., Wendt, C.W., and Clark, L.E. 1983. Drought tolerant sorghum and cotton germplasm. In Plant Production and Management under Drought Conditions, J.F. Stone and W.O. Willis, Eds. The Netherlands Elsevier Science Publishers B.V., Amsterdam, pp. 207-222.

Rosenow, D.T., Woodfin, C.A., Clark, L.E., and Sij, J.W. 1999. Drought resistance in exotic sorghum. In Agronomy Abstracts. Agronomy Society of America, Madison, WI, p. 166.

Sajjanar, G.M. 2002. Genetic Analysis and Molecular Mapping of Components of Resistance to Shoot Fly [Atherigona soccata Rond.] in Sorghum [Sorghum bicolor (L.) Moench]. Ph.D. thesis, University of Agricultural Sciences, Dharwad, India, 2002.

Schaffert, R.E., McCrate, A.J., Trevisan, W.L., Bueno, A., Meira, J.L., and Rhykerd, C.L. 1975. Genetic variation in Sorghum bicolor (L.) Moench for tolerance to high levels of exchangeable aluminium in acid soils of Brazil. In Proceedings of Sorghum Workshop, University of Puerto Rico, Mayaguez, Puerto Rico, pp. 151-160. 
Schertz, K.F. 1994. Male sterility in sorghum: its characteristics and importance. In Use of Molecular Markers in Sorghum and Pearl Millet Breeding for Developing Countries, Proceedings of an ODA Plant Sciences Research Conference, J.R. Witcombe and R.R. Duncan, Eds., Norwich, U.K., March 29-April 1, 1993, pp. 35-37.

Schertz, K.F., Stec, A., and Deobley, J.F. 1990. Isozyme Genotypes of Sorghum Lines and Hybrids in the United States, Texas Agricultural Experimental Station 1719, Lubbock, TX, p. 15.

Seetharama, N., Mythili, P.K., Rani, T.S., Harshvardhan, D., Ranjani, A., and Sharma, H.C. 2003. Tissue culture and alien gene transfer in sorghum. In Plant Genetic Engineering, Vol. 2, Improvement of Food Crops, P.K. Jaiwal and R.P. Sing, Eds. Sci Tech Publishing LLC, pp. 235-265.

Seetharama, N., Reddy, B.V.S., Peacock, J.K., and Bidinger, F.R. 1982. Sorghum improvement for drought resistance. In Drought Resistance in Crop Plants with Emphasis on Rice. IRRI, Philippines, pp. 317-356.

Shan, L.Q., Ai, P.J., Yin, L.T., and Yao, Z.F. 2000. New grain sorghum cytoplasmic male-sterile A2V4A and F1 hybrid Jinza no.12 for northwest China. Int. Sorghum Millets Newsl. 41: 31-32.

Sharma, H.C. 1993. Host plant resistance to insects in sorghum and its role in integrated pest management. Crop Prot. 12: 11-34.

Sharma, H.C., Abraham, C.V., Vidyasagar, P., and Stenhouse, J.W. 1996. Gene action for resistance in sorghum to midge, Contarinia Sorghicola. Crop Sci. 36: 259-265.

Sharma, G.C., Jotwani, M.G., Rana, B.S., and Rao, N.G.P. 1977. Resistance to sorghum shoot fly [Atherigona Soccata Rondani] and its genetic analysis. J. Ent. Res. 1: 1-12.

Sifuentes, J. and Frederiksen, R.A. 1988. Inheritance of resistance to pathotypes 1, 2 and 3 of Peronosclerospora sorghi in sorghum. Plant Dis. 72: 332-333.

Singh, B.V. and Rana, B.S. 1994. Influence of varietal resistance on disposition and larval development of stalk borer, Chilo Partellus Swinhoe and its relationship to field tolerance in sorghum. Insect Sci. Application 5: 287-296.

Singh, G., Singh, H.C., Ramakrishna, and Singh, S. 2001. Genetic divergence in Sorghum bicolor (L.) Moench. Ann. Agric. Res. 22: 229-231.

Singh, R. and Axtell, J.D. 1973. High lysine mutant gene $(h l)$ that improves protein quality and biological value of grain sorghum. Crop Sci. 13: 535.

Singhania, D.L., Deosthale, Y.G., and Rao, N.G.P. 1979. A study of gene action for protein and lysine content in sorghum (Sorghum bicolor (L) Moench). Indian J. Hered. 11: 25-34.

Snowden, J.D. 1936. The Cultivated Races of Sorghum. Allard and Co., London.

Spearman, C. 1904. General intelligence objectively determined and measured. Am. J. Psychol. 25: 201-293.

Stephens, J.C. 1937. Male sterility in sorghum: its possible utilization in production of hybrid seed. J. Am. Soc. Agron. 29: 690-696.

Stephens, J.C. and Holland, R.F. 1954. Cytoplasmic male-sterility for hybrid sorghum seed production. Agron J. 46: 20-23.

Subudhi, P.K. and Nguyen, H.T. 2000. New horizons in biotechnology. In Sorghum, Origin, History, Technology and Production, Wiley Series in Crop Science, C.W. Smith and R.A. Frederiksen, Eds. John Wiley \& Sons, New York, pp. 349-397.

Subudhi, P.K., Rosenow, D.T., and Nguyon, H.T. 2000. Quantitative trait loci for the stay-green trait in sorghum (Sorghum bicolor (L.) Moench): consistency across genetic backgrounds and environments. Theor. Appl. Genet. 101: 733-741.

Sullivan, C.Y. 1972. Mechanisms of heat and drought resistance in grain sorghum and methods of measurements. In Sorghum in the Eighties, N.G.P. Rao and L.R. House, Eds. Oxford and IBH Publishing Co., New Delhi, pp. 247-263.

Sullivan, C.Y. and Ross, W.M. 1979. Selecting for drought and heat resistance in grain sorghum. In Stress Physiology in Crop Plants, H. Mussell and R.C. Staples, Eds. Wiley Interscience, New York, pp. 263-281.

Tabo, R., Ogungible, A.O., Gupta, S.E., and Ajayi, O. 1999. Participatory evaluation of sorghum cultivars in northern Nigeria. Int. Sorghum Millet Newsl. 40: 36-38.

TAES and USDA-ARS. 1996. Release of converted exotic lines from the world sorghum collection.

Tanksley, S.D., Young, N.D., Paterson, A.H., and Bonierbale, M.W. 1989. RFLP mapping in plant breeding: new tool for an old science. Biotechnology 7: 257-264. 
Tao, Y.Z., Hardy, A., Drenth, J., Henzell, R.G., Franzmann, B.A., Jordan, D.R., Bulter, D.G., and McIntyre, C.L. 2003. Identification of two different mechanisms for sorghum midge resistance through QTL mapping. Theor: Appl. Genet. 107: 116-122.

Tao, Y.Z., Henzell, R.G., Jordan, D.R., Butler, D.G., Kellu, A.M., and McIntyre, C.L. 2000. Identification of genomic regions associated with stay-green in sorghum by testing RILs in multiple environments. Theor. Appl. Genet. 100: 1125-1232.

Tao, Y.Z., McIntyre, C.L., and Henzell, R.G. 1996. Applications of molecular markers to Australian sorghum breeding programs. I. Construction of a RFLP map using sorghum recombinant inbred lines. In Proceedings of the Third Australian Sorghum Conference, M.A. Foale, R.G. Henzell, and J. Kneipp, Eds., Tamworth, Australia, February 20-22, pp. 443-450.

Tarr, S.A.J. 1962. Diseases of Sorghum, Sudangrass and Brown Corn. The Commonwealth Mycological Institute, Kew, Surrey, U.K., p. 380.

Thakur, R.P., Frederiksen, R.A., Murty, D.S., Reddy, B.V.S., Bandyaophayay, R., Giorda, L.M., Odvody, G.N., and Claflin, L.E. 1997. Breeding for disease resistance in sorghum. In International Conference on Genetic Improvement of Sorghum and Pearl Millet, Lubbock, TX, September 22-27, 1996, pp. 303-315.

Thimmaraju, R., Krishna, T.G., Kuruvinashetti, M.S., Ravikumar, R.L., and Shenoy, V.V. 2000. Genetic diversity among sorghum genotypes assessed with RAPD markers. Kamataka J. Agric. Sci. 13: $564-569$.

Thomas, G.L. 1980. Thermal and Photo Thermal Effects on the Growth and Development of Diverse Grains Sorghum Genotypes. Ph.D. dissertation, Texas A\&M University, College Station, 1980.

Tipton, K.W., Floyd, E.H., Marshall, J.G., and McDevitt, J.B. 1970. Resistance of certain grain sorghum hybrids to bird damage in Louisiana. Agron. J. 62: 211-213.

Trouche, G., Rami, J.E., and Chantereau, J. 1998. QTLs for photoperiod response in sorghum. Int. Sorghum Millets Newsl. 39: 94-96.

Tuinsta, M.R., Grote, E.M., Goldsbrough, P.B., and Ejeta, G. 1996. Identification of quantitative trait loci associated with pre-flowering drought tolerance in sorghum. Crop Sci. 36: 1337-1344.

Tuinsta, M.R., Grote, E.M., Goldsbrough, P.B., and Ejeta, G. 1997. Genetic analysis of post-flowering drought tolerance and components of grain development in Sorghum bicolor (L.) Moench. Mol. Breed. 3: 439-448.

Tuinsta, M.R., Grote, E.M., Goldsbrough, P.B., and Ejeta, G. 1998. Evaluation of near-isogenic sorghum lines contrasting for QTL markers associated with drought tolerance. Crop Sci. 38: 825-842.

Turner, N.C. 1979. Drought resistance and adaptation to water deficits in crop plants. In Stress Physiology in Crop Plants, H. Mussel and R.C. Staples, Eds. Wiley Interscience New York, pp. 343-372.

Umakanth, A.V., Madhusudhana, R., Madhavilatha, K., Hema Kumar, P., and Kaul, S. 2002. Genetic architecture of yield and its contributing characters in postrainy-season sorghum. Intl Sorghum Millet Newsl. 43: 37-39.

Van Oosterrom, E.J., Jayachandran, R., and Bidinger, F.R. 1996. Diallel analysis of the stay-green trait and its components in sorghum. Crop Sci. 36: 549-555.

Vavilov, N.I. 1992. Origin and Geography of Cultivated Plants, V.F. Dorofeev, Ed. Cambridge University Press, Cambridge, U.K., p. 332.

Vidyabhushanam, R.V., Rana, B.S., and Reddy, Belum V.S. 1989. Use of Sorghum Germplasm and Its Impact on Crop Improvement in India. Paper presented at Collaboration on Genetic Resources: Summary Proceedings of a Joint ICRISAT/NBPGR (ICAR) Workshop on Germplasm Exploration and Evaluation in India, Patancheru, India, November 14-15, 1988.

Virupaksha, T.K. and Sastry, L.V.S. 1968. Studies on the protein content and amino acid composition of some varieties of grain sorghum. J. Agric. Food Chem. 16: 199-203.

Virupaksha, T.K. and Sastry, L.V.S. 1969. Alcohol soluble proteins of grain sorghum. Cereal Chem. 46: 284-293.

Volger, R.K. 1992. Genetic Control of Low Stimulant Production and Its Potential as a Predictor of Field Resistance against Striga asiatica in Sorghum. M.Sc. thesis, Purdue University, West Lafayette, IN, 1992.

Volger, R.K., Ejeta, G., and Bulter, L.G. 1995. Integrating biotechnological approaches for the control of Striga. Afr. Crop Sci. J. 3: 217-222. 
Vose, P.B. 1987. Genetic aspects of mineral nutrition: progress to date. In Genetic Aspects of Plant Mineral Nutrition, W.H. Gabelman and B.C. Loughman, Eds. Martinus Nijhoff Publishers, Dordrecht, The Netherlands, pp. 3-13.

Waggle, D.H. and Deyoe, C.W. 1966. Relationship between protein level and amino acid composition of sorghum grain. Food Stuffs 38: 18-19.

Wall, J.S. and Blessin, C.W. 1970. Composition of sorghum plant and grain. Sorghum Production and Utilization, J.S. Wall and W.M. Ross, Eds., AVI Pub., Westport, CT, pp. 118-166.

Webster's Ninth New Collegiate Dictionary. 1986. Merriam-Webster, Springfield, MA.

Wendorf, F., Close, A.E., Schild, R., Wasylikowa, K., Housley, R.A., Harlan, R.A., and Krolik, H. 1992. Saharan exploitation of plants 8000 years B.P. Nature 359: 721-724.

Wenzel, W.G. 1994. Tillering, panicle mass and threshability as components of yield in grain sorghum. Int. Sorghum Millets Newsl. 35: 72-73.

Witcombe, J.R. and Duncan, R.R. 1994. Use of molecular markers in sorghum and pearl millet breeding for developing countries. In Proceedings of an ODA Plant Sciences Conference, Norwich, U.K. March 29-April 1, 1993.

Witcombe, J.R., Joshi, J.R., Joshi, K.D., and Sthapit, B.R. 1996. Farmer participatory crop improvement. Exp. Agric. 32: 453-460.

Worede, M. and Mekbib, H. 1993. Linking genetic resource conservation to farmers in Ethiopia. In Cultivating Knowledge, Genetic Diversity, Farmer Experimentation and Crop Research, W. de Boef, K. Amanor, and K. Wellard, Eds. International Technology Publications, London, pp. 78-84.

Xu, W.W., Subudhi, P.K., Crasta, O.R., Rosenow, D.T., Mullet, J.E., and Nguyen, H.T. 2000. Molecular mapping of QTLs conferring stay-green in grain sorghum (Sorghum bicolor (L.) Moench). Genome 43: 461-469.

Yang, W., de Oliveira, A.C., Godwin, L., Schertz, K.C., and Bennetgen, J.L. 1996. Comparison of DNA marker technologies in characterizing plant genome diversity: variability in Chinese Sorghums. Crop Sci. 36: $1669-1676$.

Yang, Z. 1997. Sorghum breeding research in China. Int. Sorghum Millets Newsl. 38: 15-18.

Yu, H., Liang, G.H., and Kofoid, K.D. 1991. Analysis of C-banding chromosome patterns of sorghum. Crop Sci 31: 1524-1527.

Zake, V.M., Watson, C.E., Jr., and Gourley, L.M. 1992. In Proceedings of Workshop on Adaptation of Plants to Soil Stresses, Lincoln, NE, August 1-4, 1993, pp. 80-99. 